\author{
UNIVERSIDADE DE SÃO PAULO \\ FACULDADE DE FILOSOFIA, LETRAS E CIÊNCIAS HUMANAS \\ DEPARTAMENTO DE LETRAS MODERNAS \\ PROGRAMA DE PÓS-GRADUAÇÃO EM LÍNGUA ALEMÃ
}

\title{
BEZIEHUNGSWEISE E SUAS CORRESPONDÊNCIAS EM PORTUGUÊS
}

\author{
Alexandre Michellin Tristão
}

\begin{abstract}
Dissertação apresentada ao Programa de Pós-Graduação em Língua Alemã, do Departamento de Letras Modernas da Faculdade de Filosofia, Letras e Ciências Humanas da Universidade de São Paulo, para obtenção do título de Mestre em Letras.
\end{abstract}

Orientadora: Profa. Dra. Selma Martins Meireles 
Beziehungsweise e suas

correspondências em português

Dissertação de mestrado

Alexandre Michelin Tristão

PPLLA - DLM/FFLCH-USP

Banca Examinadora: 
A meus pais, Sebastião Tristão Filho e Jacira de Lourdes Michellin Tristão, que me deram a vida;

A meus irmãos Adriana Michellin Tristão e André Michellin Tristão, que cresceram comigo;

À Lúcia Tristão e Sebastião Tristão, e a Frederico Michellin (in memoriam) meus queridos avós paternos e materno respectivamente, que também estão presentes em minha vida. 


\section{AGRADECIMENTOS}

Aos meus pais Sebastião Tristão Filho e Jacira de Lourdes Michellin Tristão, que sempre me incentivaram a estudar;

À Profa. Dra. Selma Martins Meireles, pela confiança em mim e pela orientação;

Aos queridos amigos Alessandra Monteiro de Castro Trigo, Alexandre Casciano, Carolina de Pontes Rubira, Cristina Caliolo, Deborah Rodrigues Moreira, Edna de Sousa Albino, Fabiana de Pontes Rubira, Nemias Cordeiro de Albuquerque que me acompanharam nesse período. 


\section{RESUMO}

A presente dissertação tem por objetivos identificar os contextos de uso da conjunção beziehungsweise (bzw.) em textos escritos da língua alemã e estabelecer possíveis correspondências em português. A problemática levantada é a da expressão da alternatividade, sendo que o alemão possui uma palavra específica (beziehungsweise) para marcar situações que não são diferenciadas sintática e semanticamente em português. Para tanto, foi elaborado um corpus com 104 ocorrências autênticas de uso de bzw. retirados do site Wortschatz (Universidade de Leipzig, Alemanha), composto em sua grande maioria de exemplos provenientes da revista alemã Der Spiegel. Os exemplos foram traduzidos para o português e revisados por uma tradutora profissional. As ocorrências assim traduzidas foram agrupadas segundo as três possibilidades de uso de bzw. indicadas no Langenscheidt Grosswörterbuch Deutsch als Fremdsprache (2003), bem como segundo as suas traduções para o português. Todos os três tipos de uso estão representados no corpus. O tipo que expressa relação biunívoca, apesar de apresentar a menor freqüência de uso, é o mais homogêneo em termos de tradução para o português. O tipo com segunda maior freqüência é o de precisão da informação, no qual bzw. assume o papel de um focalizador, expandindo ou restringindo o foco da informação. $O$ tipo de maior ocorrência expressa a alternatividade propriamente dita, sendo que $b z w$. pode ser usado para relacionar alternativas excludentes ou não excludentes. Os resultados obtidos mostraram que, em português, as traduções mais apropriadas para beziehungsweise, de acordo com sua freqüência de uso, são as conjunções "e", "ou" e o advérbio "respectivamente". No entanto, os usos da conjunção beziehungsweise em alemão atualmente não se restringem às correspondências indicadas nos dicionários bilíngües alemão-português.

Palavras-chave: beziehungsweise; alternatividade; conjunção; tradução; língua alemã 


\begin{abstract}
This study intends to identify contexts of usage of the conjunction beziehungsweise (bzw.) in written texts in German language and establish possible correspondences in Portuguese. The issue raised is the expression of coordination of alternatives. German has a specific word (beziehunghsweise) to mark situations that are not differentiated syntactically and semantically in Portuguese. Therefore, a corpus comprising 104 authentic items was compiled from the site Wortschatz (Leipzig University, Germany), most of which from the magazine Der Spiegel. The examples were translated into Portuguese and reviewed by a professional translator. The translated samples were separated into groups according to three possibilities of usage of the conjunction presented in the Langenscheidt Grosswörterbuch Deutsch als Fremdsprache (2003) and their translation into Portuguese. All three types of usage are represented in the corpus.

The type that expresses a one-to-one relation, despite presenting the smallest frequency in the corpus, is the most homogeneous referring to Portuguese translation and meaning. The second most frequent type is one that details information, in which bzw. plays a role in order to focus the information, expanding or limiting its focus.

The most frequent type expresses in fact the alternative coordination, with beziehungsweise connecting either excluding or non-excluding alternatives. The results showed that the most appropriate translation of beziehungsweise into Portuguese, according to its usage frequency, are the conjunctions e ("and"), ou ("or") and the adverb respectivamente ("respectively").

However, the usage of the conjunction beziehungsweise in current German is not limited to its meanings as presented in bilingual German-Portuguese dictionaries.
\end{abstract}

Keywords: beziehungsweise, conjunction, alternatives, translation, German language 


\section{ZUSAMMENFASSUNG}

In dieser Dissertation geht es um den Gebrauch der Konjunktion beziehungsweise (bzw.) in deutschen Texten geschriebener Sprache, sowie ihre möglichen Entsprechungen auf Portugiesisch. Es handelt sich um den Ausdruck der Alternativität, denn das Deutsche verfügt über ein spezifisches Wort (beziehungsweise), das in solchen Kontexten Situationen definiert, die auf Portugiesisch weder semantisch noch syntaktisch differenziert werden. Mit diesem Zweck wurde ein Korpus mit 104 authentischen Beispielen von bzw. aus der Webseite Wortschatz (Universität Leipzig) erstellt, die meisten davon aus der Zeitschrift Der Spiegel. Die Belege wurden ins Portugiesisch übersetzt und die Übersetzungen von einer Berufsübersetzerin revidiert. Die auf diese Weise gewonnenen Beispielen wurden nach den drei vom Langenscheidt Grosswörterbuch Deutsch als Fremdsprache (2003) angegebenen Gebrauchsmöglichkeiten sowie nach ihren Übersetzungen auf Portugiesisch gruppiert. Alle drei Gebrauchsarten sind im Korpus verteten. Die Variante, die eine eineindeutige Relation markiert, weist zwar den niedrigesten Prozentsatz, ist aber die homogenste Gruppe in Bezug auf die portugiesische Übersetzung. Die zweithäufigste Gruppe dient der Präzisierung der Information mit bzw. als Element, womit einen breiteren oder geringeren Informationsfokus erzeugt wird. Die meist frequente Gruppe drückt die Alternativität im engeren Sinn aus. Hier kann die Konjunktion bzw. ein- oder ausschließende Alternativen verbinden. Es wurde festgestellt, dass die passenden Übersetzungen für beziehungsweise auf Portugiesisch die Konjunktionen „e“, „ou“ und das Adverb „respectivamente“ sind. Dennoch schränken sich die gegenwärtigen Gebrauchstarten der Konjunktion beziehungsweise nicht auf die in den zweisprachigen Wörterbüchern angegebenen Entsprechungen.

Schlüsselwörter: beziehungsweise; Alternativität; Konjunktion; Übersetzung; Portugiesisch 
INTRODUÇÃO ..............................................................................................................................................

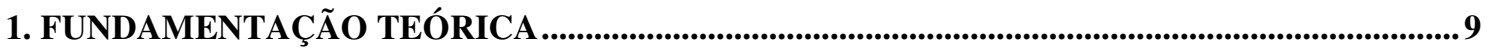

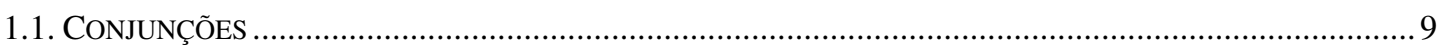

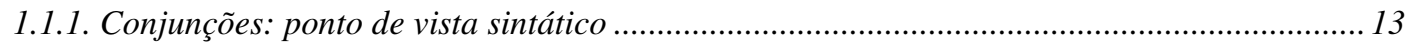

1.1.2. Conjunções coordenativas: ponto de vista semântico ....................................................... 17

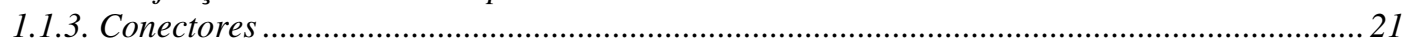

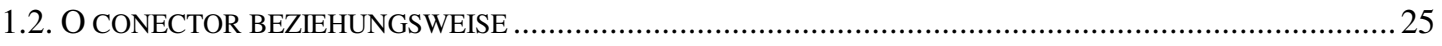

1.2.1. Definição em dicionários monolíngues em língua alemã .......................................................25

1.2.2. Definição em dicionários bilíngües alemão-português.........................................................29

1.2.3. Definição em gramáticas em língua alemã........................................................................ 30

2. CORPUS E METODOLOGIA....................................................................................................................35

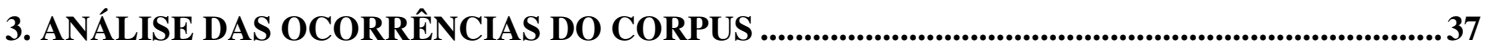

3.1 ANÁLISE DAS OCORRÊNCIAS POR TIPO DE USO E TRADUÇÃO PARA O PORTUGUÊS ................................39

3.1.1 Tipo A - duas informações correspondem biunivocamente a duas outras .................................39

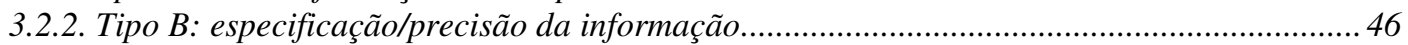

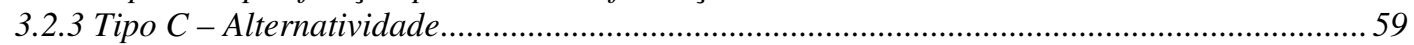

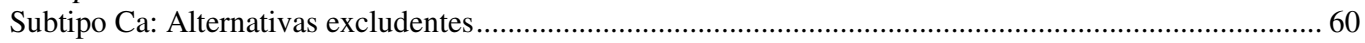

Subtipo Cb: Alternativas não-excludentes................................................................................... 70

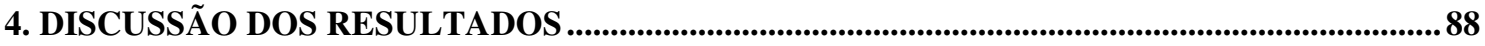

5. CONSIDERAÇÕES FINAIS.....................................................................................................................93

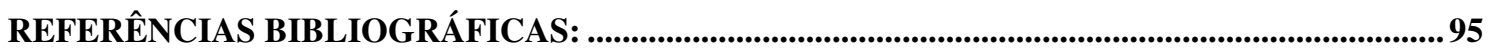




\section{INTRODUÇÃo}

A presente dissertação de mestrado consiste em um estudo do emprego da conjunção coordenativa beziehungsweise (abreviação: bzw.) na língua alemã e de suas possíveis correspondências em português, de modo a facilitar o entendimento e a compreensão de seu uso por parte de brasileiros falantes de alemão como língua estrangeira, bem como auxiliar na tradução e no ensino de língua alemã como língua estrangeira.

A problemática levantada na dissertação enfoca a diferença de recorte que a língua alemã e a língua portuguesa apresentam para expressar a alternatividade, bem como as relações estabelecidas através da conjunção beziehungsweise.

Dessa forma, esta pesquisa tem como objetivos:

- identificar os contextos de uso da conjunção beziehungsweise em textos escritos da língua alemã;

- a partir de tais contextos, estabelecer possíveis correspondências para beziehungsweise em português.

Para a realização deste estudo, foi elaborado um corpus lingüístico baseado em exemplos autênticos e de uso corrente na língua alemã, composto por material da língua escrita.

O trabalho divide-se em dois blocos. O primeiro consiste em um levantamento bibliográfico sobre conjunções em geral em seu âmbito sintático e semântico. Definições de dicionários monolíngües e bilíngües, bem como de gramáticas do alemão servem como ponto de partida para o estudo específico da conjunção beziehungsweise.

O segundo bloco é composto pela análise do corpus e seus resultados. Nessa parte, são analisados os dados coletados e suas traduções, seguidos de sua discussão e das considerações finais. 


\section{FUNDAMENTAÇÃO TEÓRICA}

Beziehungsweise (bzw.) é uma conjunção alemã que tem por função relacionar frases, palavras e orações, estabelecendo uma relação de interação entre esses elementos, que pode ser copulativa, especificativa ou alternativa.

Esta pesquisa foi motivada pelo interesse em estabelecer possibilidades de tradução da conjunção $b z w$. em português. $O$ estudo da literatura sobre 0 tema e de exemplos autênticos indicam que há usos desta conjunção em que não há uma expressão completamente equivalente em português, como mostro no decorrer desta dissertação.

A seguir, apresento algumas considerações básicas sobre o conceito de conjunção em geral e bzw. em particular, como base teórica para a pesquisa empírica.

\subsection{Conjunções}

De acordo com a definição de BARROS (1985:213), a conjunção "é a palavra que relaciona duas orações ou dois termos semelhantes da mesma oração"; do ponto de vista sintático, exercem a mesma função, como nos exemplos a seguir:

Ele só quer sombra e água fresca.

Esperei-o até tarde, mas ele não veio.

Todos sabiam que ele viria.

No exemplo (1), a conjunção "e" relaciona duas palavras de mesma categoria gramatical: "sombra" e "água" são substantivos. No exemplo (2), a conjunção "mas" une orações de sentido completo, ou seja, a ação "esperar" e a ação "vir" são independentes entre si. Por fim, no exemplo (3), temos a conjunção "que" unindo duas orações através de uma relação de subordinação, na qual a segunda oração é dependente da primeira, pois não possui um sentido completo.

Diferentemente dos adjetivos, verbos e substantivos, morfologicamente as conjunções são invariáveis, ou seja, não possuem gênero, nem número e tampouco grau. Quanto à classificação, elas podem ser de dois tipos: 
coordenativas e subordinativas. Ainda segundo BARROS (1985:213), "se dois termos têm idêntica função gramatical, as conjunções se denominam coordenativas; se 'ligam' duas orações, uma das quais determina ou completa o sentido da outra, chamam-se subordinativas". Nas frases "O buraco de ozônio cresceu e continua se expandindo" e "Os cientistas descobriram que a camada de ozônio está diminuindo a cada ano", FARACO \& MOURA (1993:270) nos fornecem exemplos da relação de coordenação exercida pela conjunção "e" e a relação de subordinação exercida pela conjunção "que".

A conjunção pode também conectar duas unidades menores que a oração, desde que de igual valor funcional dentro do enunciado:

Gustavo e Gabriel são gêmeos. (substantivos)

Partirei com ou sem você. (preposições)

Além disso, as conjunções podem ser classificadas quanto ao seu emprego nos diversos contextos. Segundo FARACO \& MOURA (1993:270), as principais conjunções coordenadas podem ser classificadas como aditivas, adversativas, conclusivas, explicativas e alternativas. Todos esses tipos de conjunções estabelecem uma relação específica entre os termos que unem.

Aditivas: apresentam relação de adição ou soma.

Ele só quer sombra e água fresca.

Ele joga tênis e basquete.

Ele não só fala árabe, mas também escreve.

Adversativas: apresentam uma relação de oposição.

Esperei-o até tarde, mas ele não veio.

Pagou a mais, porém não Ihe deram o troco.

Conclusivas: apresentam uma relação de conclusão.

Ele estava com fome, logo comeu o peixe.

Ele não recebeu o pedido, logo não entregará a mercadoria.

Explicativas: apresentam uma relação de justificativa. 
Provavelmente amanhã não teremos bom tempo, pois o céu está nublado.

Não julguemos pelas aparências, pois as aparências enganam.

Alternativas: apresentam uma relação de alternância.

Não sei se leio a revista ou se leio o livro.

Não sei se me caso ou se compro uma bicicleta.

Em língua alemã, a definição de conjunção não difere muito daquela em língua portuguesa: as conjunções, diferentemente das preposições, não regem casos e unem palavras, grupos de palavras ou orações e partes de orações entre si.

De acordo com a DUDEN Grammatik, obra de referência para a língua alemã, "as conjunções (conjunção, palavra de ligação) servem para ligar palavras, grupos de palavras ou frases entre si. Não podem se comportar como sintagma ou atributo (cf. 1995: 390)."1 A última versão da mesma gramática ressalta que nem todas as conjunções atuam em todos os níveis. Como exemplo, citam-se as conjunções sowie ["assim como"], que nunca une orações, e denn ["pois"], que só é utilizada para unir orações. (cf. DUDEN 2005: 628ss). Os exemplos a seguir ilustram possibilidades de atuação das conjunções em alemão (cf. DUDEN 1995: 391):

Conjunções coordenadas (nebenordnende Konjunktionen):

Peter und Frauke, Vater oder Mutter.

(Peter e Frauke, pai ou mãe.)

Conjunções de sintagmas (Satzteilkonjunktionen)

Er benimmt sich wie ein Vogel.

(Ele se comporta como um pássaro.)

Conjunções infinitivas (Infinitivkonjunktionen)

Wir fahren an die See, um uns zu erholen.

(Vamos ao mar para nos divertirmos.)

Die Konjunktionen (Bindewörter, Fügewörter) dienen dazu, Wörter, Wortgruppen oder Sätze miteinander zu verbinden. Sie können weder als Satzglied noch als Attribut auftreten. (DUDEN 1995: 390) - Todas as traduções de citações aqui apresentadas são de minha autoria. 
Conjunções subordinadas (unterordnende Konjunktionen).

Wir fuhren nach Frankfurt, weil wir zum Flughafen wollten.

(Fomos a Frankfurt porque queríamos ir para o aeroporto.)

A tradição alemã faz uma distinção entre Konjunktionen (conjunções coordenativas) e Subjunktionen (conjunções subordinativas). Tratarei esse aspecto em maiores detalhes no capítulo sobre os Conectores. Como esta pesquisa tratará apenas da conjunção alemã beziehungsweise (freqüentemente usada em sua forma abreviada $b z w$ ), utilizarei sempre o termo em português "conjunção".

A versão mais atual da DUDEN Grammatik classifica as conjunções coordenativas em seis grupos, a saber: conjunções aditivas (additiv), alternativas (alternativ), adversativas (adversativ), concessivas (konzessiv) especificativas (spezifizierend), causais (kausal) e comparativas (vergleichend (cf. DUDEN 2005: 629 a 631).

BusCHA (cf. 1989:06) considera as conjunções, essencialmente, como não flexionáveis morfologicamente. A respeito do modo de classificação, são divididas em conjunções coordenativas e em conjunções subordinativas. $\mathrm{Na}$ coordenação, podem unir também sintagmas e partes de sintagmas (atributos) $)^{2}$, como mostram os exemplos a seguir:

Du kannst ihm schreiben, oder du kannst ihm (auch) anrufen.

(Você pode escrever a ele, ou pode lhe telefonar.)

Du kannst ihm schreiben, oder (auch) anrufen.

(Você pode escrever a ele, ou telefonar-lhe.) (BuschA 1989: 95)

Assim, pode-se dizer que tanto em alemão como em português as conjunções são invariáveis; unem palavras, frases e sintagmas; dividem-se em dois grupos, as coordenativas e as subordinativas. As orações coordenadas mantém os elementos independentes entre si e as orações subordinadas estabelecem uma relação de dependência de sentido entre os elementos que estão ligados por elas.

2 Im vorliegenden Lexicon werden sie primär als morphologische (nicht flektierbare) Wörter bestimmt, (...) Nach der Art der Verknüpfung ist zwischen koordinierenden (beiordnenden)und subordinierenden (unterordnierenden) Konjunktionen zu unterscheiden. In koordinierender Funktion können die Konjunktionen auch Satzglieder und Satzgliedteile (Attribute) miteinander verknüpfen. 
Morfologicamente, as conjunções podem consistir em uma ou mais palavras, como é o caso da conjunção infinitiva um zu (cf. DUDEN 2005:639), em Sie ist gekommen, $\underline{u m}$ ihrer Mutter zu helfen. (Ela veio para ajudar sua mãe) e dos demais exemplos a seguir:

Sowohl die Platten als auch die CDs waren beschädigt.

(Tanto os discos de vinil como os CDs estavam estragados.)

Weder die Mutter, noch der Vater haben etwas gemerkt.

(Nem a mãe e nem o pai perceberam algo)

(cf. DUDEN 2005: 629)

\subsubsection{Conjunções: ponto de vista sintático}

A definição de Celso CunHA resume o papel sintático da conjunção:

As palavras invariáveis que servem para relacionar duas orações ou dois termos semelhantes da mesma oração chamam-se CONJUNÇÕES. As CONJUNÇÕES que relacionam termos ou orações de idêntica função gramatical têm 0 nome de COORDENATIVAS. Denominam-se SUBORDINATIVAS as [conjunções] que ligam duas orações, uma das quais determina ou completa o sentido da outra (CUNHA 1978:391).

Se considerarmos a conjunção como assumindo a função de simples instrumento de ligação entre frases (nos casos em que se trata de uma relação de coordenação), pode-se dizer que ela não pertence à frase no sentido de não ser essencial, como mostram os seguintes exemplos:

Maria chorava. Tinha tudo para ser feliz.

Maria chorava e tinha tudo para ser feliz. (BARROS 1985:217) 
Heute gehen wir ins Kino. Morgen bleiben wir zu Hause.

(Hoje vamos ao cinema. Amanhã ficamos em casa.)

Heute gehen wir ins Kino, und morgen bleiben wir zu Hause.

(Hoje vamos ao cinema e amanhã ficamos em casa - WeLKER 2001:241)

Sie kommt, geht wann sie will.

(Ela vem, vai quando quer.)

Sie kommt und geht, wann sie will.

(Ela vem e vai quando quer. - (ZIFONUN 1997:2377)

No entanto, HENTSCHEL e WEYDT vão além desta visão:

conjunções são palavras que unem orações e partes de orações entre si. Não possuem o status de membros da oração, sua posição na frase é em geral fixa e não podem ser elicitadas através de perguntas. Além de sua função sintática, unir elementos entre si, podem também determinar o tipo de relação semântica entre esses elementos (por exemplo, como temporal ou adversativa. - cf. 1994: 257) $)^{3}$

Em português as conjunções coordenadas e subordinadas não são diferenciadas por sua posição na oração, tampouco determinam mudanças na ordem direta em relação a sujeito e predicado:

a) Fique tranquilo que a dor já passa. (cf. FARACO \& MOURA 1993:271)

b) A luta seria pior que a das feras. (cf. CeLSO CuNHA 1970:265)

No exemplo a) temos uma conjunção coordenada e no exemplo b) temos uma conjunção subordinada. O uso de ambos os tipos de conjunções não alterou a posição que os outros elementos ocupam na frase.

Em língua alemã, as conjunções coordenadas (Konjunktionen) não alteram a colocação dos verbos nas orações, enquanto o uso de conjunções subordinativas (Subjunktionen) sintaticamente altera a colocação do verbo conjugado, deslocando-o para a posição final da oração. Desse modo, há uma diferença na estrutura sintática das orações introduzidas por conjunções subordinativas.

3 "Konjunktionen sind Wörter, die Sätze oder Satzteile miteinander verbinden. Sie haben keinen Satzgliedwert (Satzglied), ihre Stellung im Satz ist gewöhnlich festgelegt, und sie können nicht erfragt werden. Neben ihrer syntaktische Funktionen, Elemente miteinander zu verknüpfen, können sie auch die Art der Beziehung zwischen diesen Elementen semantisch bestimmen (z.B. als eine temporale oder adversative). 
A Duden Grammatik (cf. 2005:626) divide os conectores nos tipos Konjunktion, Subjunktion, Konjunktionaladverb, de modo que:

através da conjunção coordenativa é mantida a posição normal de verbo em segunda posição na frase, com a conjunção subordinativa o verbo se desloca para a posição final da oração subordinada. Os advérbios conjuntivos, por outro lado, podem ocupar o campo inicial (Vorfeld) ou posicionar-se no meio da oração. ${ }^{4}$

Os exemplos de HeNTSCHEL \& WeYdt (cf. 1994:259) ilustram essa diferença sintática:

(1) Dagobert hat nie Zeit, weil er immer auf sein Geld aufpassen muss.

(Dagobert nunca tem tempo porque ele sempre tem que tomar conta de seu dinheiro.)

(2) Dagobert hat nie Zeit, denn er muss immer auf sein Geld aufpassen. (Dagobert nunca tem tempo porque ele sempre tem que tomar conta de seu dinheiro)

(3) Dagobert hat nie Zeit, er muss ja immer auf sein Geld aufpassen.

(Dagobert nunca tem tempo, ele sempre tem que tomar conta de seu dinheiro)

(4) Wegen der ewigen Aufpasserei auf sein Geld hat Dagobert nie Zeit. (Por causa do eterno cuidado com seu dinheiro, Dagobert nunca tem tempo.)

Como mostram os exemplos acima, há várias formas de expressar a mesma idéia, inclusive através da Subjunktion (1) e da Konjunktion (2), sem alteração de significado. No entanto, no exemplo (1), o uso da conjunção subordinativa weil obriga o deslocamento do verbo conjugado muss para o final da oração. Dessa forma, o uso de conjunções subordinativas em alemão afeta a estrutura sintática da oração subordinada.

Além disso, se utilizarmos o que ZIFONUN (cf. 1997:2362) denomina Juxtaposition, expressamos a mesma idéia sem o uso das conjunções, como mostra o exemplo (3). Neste caso, fica implícito o papel da conjunção coordenada denn.

Pode-se também fazer uso de conjunção para expressar a mesma idéia, como mostra o exemplo (4). Neste caso, também não ocorre a inversão verbal, tampouco o posicionamento do verbo ao final da oração.

${ }^{4}$ Bei Konjunktionen bleibt die normale Verbzweitstellung im Aussagesatz erhalten, bei Subjunktionen rückt das Verb an das Ende des Nebensatzes. Konjunktionaladverbien können dagegen im Vorfeld oder im Mittelfeld stehen. 
Em alemão há ainda os chamados "advérbios conjuntivos" ou Konjunktionaladverbien. Segundo Welker (2001:241), os advérbios conjuntivos são considerados conjunções por alguns gramáticos e "podem estar no meio da oração ou no início; quando estiverem em posição inicial, provocam a inversão".

Desse modo, a oração dos exemplos anteriores poderia também ser construída, sem alteração de sentido, da seguinte maneira:

(5) Dagobert muss immer auf sein Geld aufpassen, deswegen/deshalb hat er keine Zeit.

Assim, podemos concluir que, nas gramáticas pesquisadas em português, o conceito de conjunções praticamente não varia de uma obra para a outra, restringindo-se a classificá-las como coordenativas e subordinativas. As conjunções coordenativas são descritas como tendo a função de unir orações independentes entre si, enquanto as conjunções subordinativas unem orações principais e subordinadas. Seu uso nas sentenças não altera a posição de outros elementos nas orações unidas por elas, como por exemplo em "Estava calmo, embora triste." (cf. CUNHA 1970:264) que também pode ser expressa como "Embora triste, estava calmo."

Em língua alemã há uma diferenciação em nível sintático entre as conjunções coordenativas (Konjunktionen) e as conjunções subordinativas (Subjunktionen) com relação ao posicionamento do verbo na oração (cf. DUDEN 2005: 626). As primeiras não causam inversão do sujeito (i.e. não ocupam posição no campo anterior - Vorfeld) e as segundas causam o posicionamento do verbo conjugado ao final da oração. Isso implica em uma diferenciação sintática com relação ao uso das conjunções subordinativas e coordenativas na oração.

A conjunção beziehungsweise pertence ao grupo das conjunções coordenativas, assim, neste trabalho iremos nos ater apenas a essa categoria de conjunções. 


\subsubsection{Conjunções coordenativas: ponto de vista semântico}

No capítulo anterior, explicitei o ponto de vista sintático sobre as conjunções que, como já foi dito, consiste em unir palavras, frases, grupos de palavras e orações de mesma função em uma frase. Do ponto de vista semântico, as conjunções estabelecem uma relação específica entre os termos que unem. Os exemplos de WELKER (2003:242) ilustram a relação semântica estabelecida pela conjunção: em Ich habe Hunger, aber ich will nichts essen. ["Tenho fome, mas não quero comer nada"], temos uma relação de adversidade. Já em Ich gehe ins Haus, denn es ist schon kalt ["Vou entrar em casa, pois já está frio"], há uma relação de conseqüência.

Segundo FARACO \& MOURA (cf. 1993:270), Barros (cf. 1985:213) e PASCHOALIN (cf. 1996:136-137), as conjunções coordenadas em português expressam as seguintes relações semânticas: aditiva, adversativa, alternativa, conclusiva e explicativa, como mostram os seguintes exemplos de PASCHOALIN (1996:136):

a) As conjunções aditivas exprimem a idéia de adição e soma:

Ali terminava a estrada e começava o imenso cafezal.

Não veio nem telefonou.

Inês trabalha mas também estuda.

Marli não só compareceu à reunião como trouxe ótimas propostas.

b) As conjunções adversativas exprimem a idéia de adversidade, contraste e oposição:

Os operários reivindicaram aumento salarial mas não foram atendidos.

A peça foi boa, contudo não agradou aos expectadores.

Não vi meu filho, crescer no entanto está um homem.

O nosso time era o favorito, não obstante foi derrotado.

c) As conjunções alternativas apresentam a idéia de alternância, escolha:

Sem metrô, sairia bem mais cedo ou perderia a hora do serviço.

A criança ora chora, ora ri.

A vida é sempre a mesma, quer faça sol, quer faça chuva. 
d) As conjunções explicativas exprimem a idéia de explicação, dão um motivo e razão:

Corra, que vai chover logo!

É bom agasalhar-se, porque está frio lá fora.

Ele não deve ter comido muito, pois já está com fome de novo.

e) As conjunções conclusivas dão a idéia de conclusão:

Está muito frio; logo, sairei agasalhado.

O tempo ajudou, portanto a safra de arroz será boa.

Choveu vários dias sem parar, por conseguinte houve enchente no sul.

Não tenho um centavo; não viajarei, pois.

As conjunções coordenativas podem assumir mais de uma classificação semântica de acordo com o contexto em que estão empregadas. Nos exemplos a seguir, FARACO \& MOURA (1993:267) destacam o emprego da conjunção "como" em sentido causal e conformativo, em que a ação ocorre conforme uma outra ação, respectivamente:

Como não falava português, teve dificuldade de se adaptar ao Brasil.

Procedeu exatamente como lhe ordenaram.

Segundo PASCHOALIN (cf. 1996:136), as conjunções e, antes, agora, quando são adversativas quando equivalem a mas:

Paulo fala e não faz.

O bom educador não proíbe, antes orienta.

Sou muito bom; agora, bobo não sou.

Foram mal na prova, quando poderiam ter ido muito bem.

As gramáticas em língua portuguesa analisadas restringem-se a delimitar o uso de conjunções coordenativas a cinco funções: aditivas, adversativas, alternativas, conclusivas e explicativas. Em alemão também há uma classificação para as conjunções coordenativas (cf. DUDEN 2005: 628632), mas com seis funções, a saber: aditivas, adversativas, alternativas, especificativas, causais e comparativas.

Diferentemente do português, em alemão há um grupo de conjunções coordenativas que assumem a função de especificador (spezifizierend), com 
uma função explicativa. Nesse caso, a explicação oferecida mostra que a conjunção pode ter caráter restritivo ou de precisão, como destacam os exemplos da Duden Grammatik (cf. 2005:631):

Er muss zu dem Termin erscheinen, außer er ist wirklich krank.

(Ele deve marcar consulta, a não ser que esteja doente.)

Seine Kollegin bzw. Freundin war damit einverstanden.

(Sua colega, ou melhor, namorada, estava de acordo com isso.)

A seguir são apresentados exemplos de cada uma das classes de conjunções em alemão:

a) Aditivas (additive): exprimem a idéia de adição ou soma, junção de palavras, de trechos de palavras e de orações:

Er kauft eine Platte und eine $C D$.

(Ele compra um disco e um CD.)

Er kauft eine $C D$ und hört sie sich gleich an.

(Ele compra um Cd e o ouve imediatamente)

Sie kam, sah und siegte.

(Ela veio, viu e venceu)

Er muss für die Miete plus die Nebenkosten aufkommem.

(Ele deve arcar com o aluguel mais as despesas.)

(cf. DUDEN 2005: 628-629)

b) Adversativas (adversative): exprimem a idéia de contraste:

Er rief um Hilfe, allein es war zu spät.

(Ele precisava de ajuda, só que já era tarde.)

Es war ein interessanter, aber zu langer Vortrag.

(Foi um seminário interessante, mas, longo demais.)

Er kaufte keine Schallplatte, sondern eine $C D$.

(Ele não comprou disco de vinil, mas/e sim um Cd.)

(cf. DUDEN 2005:630)

Das Haus ist ziemlich klein, aber schön billig.

(A casa é bastante pequena, mas é bem barata.)

(cf. PASCH ET. AL. 2003: 01)

Ich habe nicht im Restaurant gegessen, sondern ich selbst habe zu hause gekocht

Eu não comi no restaurante, (mas sim) eu mesmo cozinhei em casa.).

(cf. WELKER 2001:243) 
c) Alternativas (alternative): exprimem idéia de alternância e possibilidade de escolha:

Sie will studieren oder ins Ausland gehen.

(Ela quer estudar ou ir ao exterior)

Man streit darüber, wie stark der Mensch durch seine Kultur bzw. seine Gene bestimmt wird.

(Discute-se o quão forte o homem é determinado através de sua cultura ou através dos genes herdados.)

Sie verkauft entweder ihre Bücher, oder ihr Klaviermoten.

(Ela vende ou seus livros, ou seu piano.)

Sie möchten gerne Auto oder Fahrrad fahren.

(Eles gostariam de ir de carro ou de bicicleta)

(cf. DUDEN 2005:629)

d) Concessivas (konzessive): expressam concessão:

Es hat zwar die ganze Zeit geregnet, aber wir sind dennoch im Schwimmbad geblieben.

(Embora chovesse o tempo todo, não deixamos de ficar na piscina.)

Er rief um Hilfe, allein es war zu spät.

(Ele pediu ajuda, contudo já era tarde)

Ich habe meinen Wohnsitz in Hamburg, allein ich bin viel unterwegs.

(Tenho minha residência em Hamburgo, contudo / só que estou sempre viajando.)

(cf. ZIFONUN 1997:2421)

e) Especificativas (Spezifierende): exprimem a idéia de especificar 0 que foi mencionado e detalhar a informação:

Sie spricht mit niemandem, außer mit ihrer Schwester.

(Ela não fala com ninguém, exceto com sua irmã.)

Die Tasche war weg bzw. Gestohlen.

(A bolsa se foi, ou melhor, foi roubada.)

(cf. DUDEN 2005:631)

f) Causais (kausale): exprimem causas e razões:

Wir gingen ins Haus, denn es wurde zu kalt draußen.

(Fomos para dentro da casa porque estava frio lá fora.)

(cf. DUDEN 2005:631) 
Ich fahre am Wochenende nach Paris, denn im Frühling ist es dort sehr schön.

(Vou no fim de semana para Paris, pois na primavera lá é muito bonito.)

(cf. Reimann 2001:201)

g) Comparativas: exprimem comparações:

Otto hat seinen Freund wie ein Vater (Bezug auf Otto) behandelt. (Otto considerava seu amigo como um pai (em relação a Otto).

Sie hat ihn als Studenten kennen gelernt.

(Ela o conheceu como estudante.)

(cf. DUDEN 2005:632)

A conjunção "conecta" elementos estabelecendo relações entre eles e, desse modo, saliento que na tradição alemã alguns autores dão uma atenção maior à função da conjunção ao invés de simplesmente descrevê-las e organizá-las em listagens.

Segundo ZIFONUN et. al. na Grammatik der Deutschen Sprache (cf. 1997:2361) o que em português tradicionalmente é chamado "conjunção", em alemão é denominado Konjunktor. Dessa forma, de acordo com ZIFONUN, "a expressão lingüística da coordenação é o conjuntor. Ele é caracterizado por unir expressões de uma categoria $\mathrm{X}$ a outras de mesma categoria $\mathrm{X}$, de modo a formar uma nova expressão de mesma categoria"

No próximo item, apresento considerações sobre a noção de conectores e sua função semântica.

\subsubsection{Conectores}

Tradicionalmente, os gramáticos na língua portuguesa afirmam que a conjunção liga orações ou relacionam orações e termos de mesma função entre si. Nesse aspecto BARROS (1985: 213), CUNHA (1972: 391), FARACO \& MOURA (1993: 269) e BECHARA (2000:194) apresentam a mesma definição para a função de uma conjunção.

Sprachlicher Ausdruck der Koordination ist der Konjunktor. Er ist dadurch charakterisiert, daß er Ausdrücke der Kategorie $X$ an Ausdrücke derselben Kategorie X, so anbindet, daß wiederum ein Ausdruck der Kategorie X. gebildet wird. 
Entretanto, Maria Helena Mira MATEus nos diz que "a coordenação pode exprimir-se por conectores ou pausas. O nexo semântico entre os elementos coordenados podem ser de conjunção, disjunção, de contrajunção e de condição-conseqüência" (1983: 395-396). Os exemplos a seguir mostram o uso de pausas e conectores: em "A escola que temos está em crise, o país está em crise, o mundo ocidental está em crise" (cf. MATEUS 1983:386), podemos constatar que nos elementos ligados através das pausas há uma seqüência lógica na união dos termos em que país, escola e mundo social estão ligados à crise. Já em "Esta noite ou vamos ao teatro ou ao cinema" (relação de exclusão) e em "Esta noite ou vamos ao teatro ou vamos ao cinema" (alternativo), a ligação entre os termos é feita pelo conector "ou".

ZiFONUN (cf. 1997:2365) também aponta para o fato de que a coordenação pode ser sinalizada através de sinais gráficos como vírgula, ponto vírgula, travessão, dois pontos, entonação da fala, e nesses casos é denominada de coordenação por "justaposição", já que não há um conector:

Das Licht ging aus, der Strom war ausgefallen.

Das Licht ging aus; der Strom war ausgefallen.

Das Licht ging aus - der Strom war ausgefallen.

Das Licht ging aus: der Strom war ausgefallen.

Das Licht ging aus $\rightarrow$ der Strom war ausgefallen.

No âmbito semântico, ENGEL (cf. 1988:740) divide os conectores em língua alemã em seis tipos:

Conectores copulativos (sinalizam um valor coletivo) und, sowie, sowohl... als auch, weder... noch

(e, bem como, tanto... quanto, nem.. nem)

Conectores adversativos (sinalizam uma contrariedade)

aber, allein, doch, jedoch, nur

(mas, contudo, porém, no entanto, apenas)

Conectores disjuntivos (sinalizam alternativas ou possibilidades de escolha)

bzw., oder, entweder... oder, respektive

(e/ou, ou, ou... ou, respectivamente)

O conector causal denn (pois)

Os conectores corretivos d.h., viel mehr (isto é, pelo contrário)

6 Grifo meu. 
Os conectores de precisão/especificadores ja, nämlich, und zwar (sim, é que, e mais precisamente. $)^{7}$

\section{PASCH (cf. 2003:01) define o termo "conector" da seguinte maneira:}

Consideramos como conectores em alemão as expressões $X$ que apresentam as seguintes características $(C)$ :

(C1) $X$ não é flexionável.

(C2) X não confere marcas de casos ao seu ambiente sintático.

(C3) O significado de $X$ é uma relação de duas partes.

(C4) Os termos do significado de $X$ são constelações fatuais (Sachverhalte)

(C5) Os termos do significado de X devem poder ser caracterizados através de orações."

Segundo Pasch, Konektoren englobam os Konjunktoren e Subjunktoren, sendo que os primeiros unem orações por coordenação e os segundos unem orações por subordinação, como mostram estes exemplos:

(a) Er trinkt Wasser und sie trinkt Milch. (Ele bebe água e ela bebe leite)

(b) Er trinkt Wasser, weil er durstig ist. (Ele bebe água porque está com sede.)

Para PASCH, "Os conjuntores são conectores coordenativos. Abrangem essencialmente o conjunto que é tradicionalmente chamado de "conjunções coordenativas" (cf. 2003:453). ${ }^{9}$ Segundo ZIFONUN (cf. 1997:2363):

À classe de palavras dos Konjunktoren pertencem expressões que são próprias para ligar características mínimas, orações, grupos de verbos, frases, palavras ou morfemas e fazer explícitas essas relações semânticas entre estas unidades. $^{10}$

7 In semantischer Hinsicht lassen sich unterscheiden:

kopulative Konjunktoren (sie signalisieren gemeinsame Geltung): und, sowie, sowohl... als auch, weder... noch

adversative Konjunktoren (sie signalisieren einen Gegensatz): aber, allein, doch, jedoch, nur, sondern disjunktive Konjunktoren (sie signalisieren Alternativen oder Wahlmöglichkeiten): bzw., oder, respektive

der kausale Konjunktor denn

die korrektiven Konjunktoren d.h., vielmehr,

die präzisierenden Konjunktoren ja, nämlich, und zwar.

8 Als "Konnektoren" sehen wir im Deutschen diejenigen Ausdrücke X an, die folgende Merkmale (M) aufweisen: (M1) $x$ ist nicht flektierbar.

(M2) $x$ vergibt keine Kasusmerkmale an seine syntaktische Umgebung.

(M3) Die Bedeutung von $x$ ist eine zweistellige Relation.

(M4) Die Relate der Bedeutung von x sind Sachverhalte.

(M5) Die Relate der Bedeutung von x müssen durch Sätze bezeichnet werden können.

9 Die Konjunktoren sind koordinierende Konnektoren. Sie umfassen im Wesentlichen die Einheiten, die traditionell "koordinierenden Konjunktionen" genannt werden.

10 Zur Wortart der KONJUNKTOREN gehören sprachliche Ausdrücke, die geignet sind, kommunikative Minimaleinheiten, Sätze, Verbgruppen, Phrasen, Wörter oder Morpheme zu verbinden und das semantische Verhältnis zwischen diesen Einheiten explizit zu machen. 
Nesta pesquisa, quando falamos em conectores, entendemos que são elementos que fazem as ligações entre as orações e grupos de palavras de maneira geral. Dessa forma, no que se refere à língua alemã, são aqui considerados conectores as conjunções coordenativas (Konjunktionen), as conjunções subordinativas (Subjunktores) e os advérbios conjuntivos (Konjunktionaladverbien). Tanto em alemão como em português a coordenação pode ser feita através de pausas com o uso de vírgulas, pontos, dois pontos ou travessões. Nestes casos, a ênfase que um conector poderia dar ao sentido da oração fica subentendido ou simplesmente não muito marcado, como mostram os exemplos a seguir:

(1) O neto reuniu toda a família e preparou uma festa para a avó.

O neto reuniu toda a família, preparou uma festa para a avó. (cf. PASCHOALIN 1996:136)

A retirada do conector "e" dá margem a outras possibilidades de interpretação para a oração. Podemos entender que: a) o neto reuniu a família (e depois) preparou a festa para a avó (uma relação de seqüência de fatos), ou b) o neto reuniu a família porque preparou uma festa para a avó (uma relação de causa).

(2) Das Licht ging aus, der Strom war ausgefallen.

(A luz apagou, acabou a energia)

Das Licht war aus, denn der Strom war ausgefallen.

(A luz apagou, pois acabou a energia) (cf. ZIFONUN 1997: 2365)

No exemplo acima, o uso do conector denn ("pois") explicita a relação de causa (a luz se foi porque a luz foi cortada.) Já no exemplo sem o conector denn, há uma relação de causa-conseqüência também implícita, mas neste caso o sentido pode ser interpretado de várias formas ("A luz apagou e acabou a energia").

Desse modo, pode-se afirmar que a ausência de um conector diminui o precisão do sentido da relação entre as sentenças. Foi verificado também, que um mesmo conector pode assumir diferentes funções de acordo com 0 contexto de uso.

A partir deste pano de fundo, a conjunção beziehungsweise é apresentada, a seguir, conforme caracterizada na literatura existente sobre o tema. 


\section{2. $O$ conector beziehungsweise}

Visto que um dos objetivos da pesquisa consiste em estabelecer possíveis correspondências para $b z w$. em português, incluímos na fundamentação teórica as definições constantes de dicionários monolíngües de alemão e dicionários bilíngües alemão-português, além de gramáticas alemãs que investigassem os aspectos semânticos da conjunção em questão.

\subsubsection{Definição em dicionários monolíngues em língua alemã}

As definições dos dicionários alemães consultados a respeito de beziehungsweise, como, por exemplo, WAHRIG (696:1968) e AGRICOLA (1992:138), não diferem muito entre si. Restringem-se a listar possíveis sinônimos como "oder, oder vielmehr; besser gesagt" [ou, ou melhor, melhor dizendo] (WAHRIG, 1968:696) e exemplificá-los.

Para AGRICOLA (cf. 1992:138), segundo os seguintes exemplos, (a) Ich bin mit ihm bekannt bzw. befreundet. (Sou conhecido dele, ou melhor, um amigo) e (b) Er wird Donnerstag bzw. Freitag zu uns kommen (Ele vem quinta ou sexta nos visitar), beziehungsweise assume o sentido de precisar a informação com um sentido explicativo (a) e alternativo (b).

KEMPCKE (cf. 2000:162), em seu Wörterbuch Deutsch als Fremdsprache, também destaca a função que beziehungsweise desempenha como especificador e precisador de informação através dos seguintes exemplos:

Er wohnt in Berlin, bzw. im Randgebiet von Berlin.

(Ele mora em Berlim, ou melhor, na periferia de Berlim.)

Sie haben sich Weihnachten, bzw. am zweiten Weihnachtsfeiertag getroffen.

(Eles se encontraram no Natal, ou melhor, na segunda noite de comemoração.)

Exemplos de mesmo teor podem ser encontrados no WAHRIG (cf. 1968:696):

Habt ihr, bzw. haben Sie eigentlich gewusst dass...

(Vocês sabiam que, ou melhor, os senhores sabiam que...) 
Ich werde zwei Theatherkarten bestellen, bzw. drei, wenn dein Freund auch mitkommen will.

(Vou pedir dois ingressos para o teatro, ou melhor, três, caso seu namorado queira vir conosco).

KEMPCKE (cf. 2000:162) aponta o uso de beziehungsweise na correlação entre pares de membros de orações relacionados de forma alternativa ${ }^{11}$, como mostram os exemplos:

Zwei Flugzeuge, ein amerikaniches, bzw. ein französisches, standen am Start.

(Dois aviões, um americano e um francês, estavam para partir.)

Salienta ainda que "os membros não podem ser claramente relacionados alternativamente"12

Sie kamen aus Hamburg bzw. aus Bremen.

(Eles(as) vieram de Hamburgo ou de Bremen)

O dicionário LANGENSCHEIDT Großwörterbuch Deutsch als Fremdsprache (cf. 2003: 172) indica três possibilidades de uso de beziehungsweise ${ }^{13}$ :

1. expressa que duas afirmações diferentes se aplicam a algo, Die Kandidaten kommen aus München bzw. aus Köln. (Os candidatos vêm de Munique ou de Colônia.)

Meine alten Schallplatten habe ich verkauft bzw. verschenkt. (Meus velhos discos de vinil eu os vendi ou os presenteei.)

2. é aplicada para especificação da informação,

Großbritannien bzw. Schottland verfügt über große Ölreserven in Nordsee.

(A Grã-bretanha, ou melhor, a Escócia dispõe de grandes reservas de petróleo no Mar do Norte. )

3. é aplicada para indicar a alternativa.

Ich könnte Sie heute bzw. morgen besuchen.

(Posso visitá-lo hoje ou amanhã.)

11 (...) gibt an, dass bei einer paarweisen Zuordnung die beiden Glieder alternativ zuzuordnen sind. (KEMPCKE 2000:162)

12 (...) die Glieder sind nicht klar alternativ zuzuordnen (idem).

13 Konjunktion; 1 drückt aus, dass auf etw. zwei verschiedene Aussagen zutreffen (wobei keine genaueren Angaben dazu gemacht werden); Abk bzw.: Die Kandidaten kommen aus München bzw. Köln (= eigene kommen aus München, eigene aus Köln); Meine alten Schallplatten habe ich verkauft bzw. verschenkt (= ich habe manche verkauft $u$. manche verschenkt) 2 verwendet um e-e Aussage zu präzisieren; $A b k$ bzw. = genauer gesagt: Großbrittanien bzw. Schottland verfügt über große Ölreserven in der Nordsee. 3 verwendet, um e-e Alternative anzugeben; Abk bzw. = oder (aber): Ich könnte Sie heute bzw. morgen besuchen. 
O dicionário DUDEN Deutsches Universal Wörterbuch (cf. 2007:301) contém duas definições para beziehungsweise:

1. oder; oder vielmehr; genauer gesagt. (ou, ou melhor, melhor dizendo).

2. und im anderen Fall (e em outro caso)

São apresentados os seguintes exemplos para cada definição: Ich war mit ihm bekannt, bzw. befreundet (Eu era conhecido dele, ou melhor, amigo) indica a especificação da informação, enquanto Ihre Tochter und ihr Sohn sind sechs bzw. acht Jahre alt (A filha e o filho dela estão com 6 e 8 anos respectivamente.) indica a relação biunívoca entre os termos.

A partir do exame das obras consultadas, as várias possibilidades de uso da conjunção beziehungsweise encontradas em gramáticas e dicionários alemães estão resumidas no quadro a seguir, juntamente com uma sugestão provisória de correspondência no português:

\begin{tabular}{|c|c|c|c|c|}
\hline $\begin{array}{l}\text { Dicionário } \\
\text { monolíngüe } \\
\text { alemão }\end{array}$ & $\begin{array}{l}\text { Explicativo/ } \\
\text { Especificativo } \\
\text { (spezifierend): } \\
\text { "ou melhor" }\end{array}$ & $\begin{array}{l}\text { Alternativo } \\
\text { inclusivo: } \\
\text { "e/ou" }\end{array}$ & $\begin{array}{l}\text { Alternativo } \\
\text { exclusivo: } \\
\text { "ou" }\end{array}$ & $\begin{array}{c}\text { Relação } \\
\text { biunívoca: } \\
\text { "respectivamente } \\
\text { " }\end{array}$ \\
\hline $\begin{array}{l}\text { Wörterbuch } \\
\text { Deutsch als } \\
\text { Fremdsprache } \\
\text { (KEMPCKE 2000) }\end{array}$ & $\mathrm{X}$ & $\mathrm{X}$ & $\mathrm{X}$ & - \\
\hline $\begin{array}{l}\text { Wörter und } \\
\text { Wendungen - } \\
\text { Wörterbuch zum } \\
\text { Deutschen } \\
\text { Sprachgebrauch } \\
\text { (AGRICOLA 1992) }\end{array}$ & $\mathrm{X}$ & $X$ & $X$ & - \\
\hline $\begin{array}{l}\text { WAHRIG } \\
\text { Deutsches } \\
\text { Wörterbuch } \\
(1968)\end{array}$ & $X$ & $X$ & $X$ & - \\
\hline $\begin{array}{l}\text { LANGENSCHEIDT } \\
\text { Großwörterbuch } \\
\text { Deutsch als } \\
\text { Fremdsprache } \\
(2003)\end{array}$ & $\mathrm{X}$ & $X$ & $X$ & - \\
\hline $\begin{array}{l}\text { DUDEN Deutsches } \\
\text { Universalwörter- } \\
\text { buch (2007) }\end{array}$ & $\mathrm{X}$ & - & - & $\mathrm{X}$ \\
\hline
\end{tabular}


Como se pode notar, grande parte dos dicionários monolíngües registram beziehungsweise de duas formas:

a) especificador da informação, que pode ser entendido por "ou seja, ou melhor" como demonstra o exemplo (KEMPCKE 2000:162):

Sie haben sich Weihnachten, bzw. am zweiten Weihnachtsfeiertag getroffen.

(Eles se encontraram no Natal, ou melhor, no segundo feriado de Natal.)

b) apresentando uma alternativa, que pode ser exclusiva ou inclusiva.

Die Kandidaten kommen aus München bzw. aus Köln.

(Os candidatos vem de Munique ou de Colônia)

No exemplo retirado do WAHRIG (cf. 1968:694), Ich werde zwei Theaterkarten bestellen, bzw. drei, wenn dein Freund auch mitkommen will (Vou pedir duas entradas para o teatro, ou melhor, três, se seu namorado também vier conosco), bzw. pode ser entendido como "ou melhor", de modo que expressa a idéia de correção da informação; ou seja, uma especificação da mesma. O mesmo ocorre em outro exemplo, Die Tasche war weg bzw. gestohlen (cf. DUDEN 2005:631) (A bolsa se foi, ou melhor, foi roubada.), onde o uso de beziehungsweise como explicativo também pode ser entendido como "ou melhor", "ou seja".

Considero que o uso alternativo de beziehungsweise apresenta duas nuances:

a) uso exclusivo: em uma sentença em que são apresentadas duas situações, um referente que realiza a ação 1 não realiza a ação 2. Assim, em Meine alten Schallplatten habe ich verkauft bzw. verschenkt (Meus discos velhos eu vendi ou(e) dei) (LANGENSCHEIDT 2003:172) significa que uns eu vendi e os outros eu dei. Ambas as ações ocorreram: vender e dar, mas elas se distribuem de forma exclusiva pelos referentes apresentados: cada referente executa ou sofre apenas uma ação.

b) já no exemplo de uso inclusivo de bzw. em caso de expressão da alternatividade, como em Ich könnte Sie heute, beziehungsweise morgen besuchen (Eu poderia visitá-lo hoje ou amanhã), há alternatividade menos 
marcada entre as opções, pois essa visita pode ser hoje ou amanhã, mas, não quer dizer necessariamente que será feita em apenas um dos dois dias.

No que se refere aos uso de beziehungsweise como especificador ou com o uso alternativo, o contexto parece ser o único elemento capaz de definir a real intenção de significado.

O dicionário DE GRUYTER é o único dicionário monolíngüe consultado que apresenta uma definição de bzw. que pode ser traduzida como "respectivamente", em português. Isto talvez se deva ao fato de esse dicionário ser específico para uso de falantes estrangeiros, embora o mesmo aconteça com LANGENSCHEIDT (2003), o qual, entretanto, não registra essa definição. É interessante também observar que este uso de bzw., que praticamente é ignorado pelos dicionários monolíngües, é a primeira definição apresentada pelos dicionários bilíngües alemão-português, como mostrado adiante.

\subsubsection{Definição em dicionários bilíngües alemão-português}

As entradas referentes a beziehungsweise em dicionários alemãoportuguês de Portugal restringem-se a variações entre "adv. respectivamente" (cf. PORTO 1987:100) e "respectivamente, ou seja...; ou então; ou antes." (cf. Porto 1986:148).

O dicionário Langenscheidts Taschenwörterbuch Portugiesisch-Deutsch [Dicionário de bolso alemão-português] registra a definição correspondente para beziehungsweise como "respectivamente, ou seja" (LANGENSCHEIDT 2001:719). O mesmo registro pode ser conferido no dicionário MICHAELIS alemão-português. (cf. 2002:54). O Dicionário Alemão-Português de TOCHTROP (1968:82) também não foge a essa definição, registrando beziehungsweise como "adv. relativamente, ou seja."

Dessa maneira, nos dicionários citados, os registros referentes a beziehungsweise são de teor explicativo ("ou seja") e especificativo ("ou melhor"), além de estabelecer uma relação de ordem ("respectivamente"). 
Em todos os dicionários alemão-português consultados, o primeiro registro para beziehungsweise é "respectivamente", que expressa uma relação de seqüência em pares ( $\mathrm{AaBb}$ ).

As segundas entradas dos dicionários bilíngües consultados registram a tradução "ou seja", mostrando o aspecto explicativo/especificador que beziehungsweise contém, excluindo-se dessa maneira o aspecto alternativo apresentado por dicionários monolíngües.

Vale salientar que todos os dicionários bilíngües consultados limitaramse a traduzir o termo bzw. sem exemplificar seu uso.

\subsubsection{Definição em gramáticas em língua alemã}

O Handbuch der Deutschen Konnektoren limita-se a listar bzw. como um advérbio conectivo (Adverbkonnektor), apresentando uma frase como exemplo de uso e indicando que tanto pode assumir um lugar no campo inicial da frase (Vorfeld) ou ocupar a "posição zero", antes do campo inicial (Vorvorfeld PASCH 2003: 702).

Segundo BuschA (cf. 1989:49), "há duas variantes a serem diferenciadas: beziehungsweise marca ou uma alternativa com o sentido de especificação do primeiro termo pelo segundo, ou uma alternativa em sentido de uma organização de ambas as partes em pares." ${ }^{14}$

Para Engel, em sua Deutsche Grammatik,

esta conjunção [bzw.] sinaliza uma validade alternativa (apenas um de ambos), referente a cada um dos conteúdos diversos. Sob determinadas circunstâncias, $b z w$. pode ser substituído por oder mas. apenas quando há referências claramente diferenciadas. A oração: Sie tranken Wein bzw. Milch, portanto, somente é correta quando apenas uma parte bebeu vinho, o resto leite; caso uma outra parte do grupo tenha bebido, por exemplo, primeiro leite e então vinho, é preciso dizer Sie tranken Wein oder Milch." (cf. ENGEL 1988:741) 15 $^{15}$

14 Es sind zwei Varianten zu unterscheiden: beziehungsweise kennzeichnet entweder eine Alternativität im Sinne einer Spezifizierung des ersten Teils durch den zweiten (a) oder eine Alternativität im Sinne einer paarweisen Zuordnung der beiden Teile (b) (BUSCHA 1989:49).

15 Dieser Konjunktion signalisiert alternative Geltung (nur eines von beiden), bezogen auf je verschiedene Sachverhalte: (...) Unter bestimmten Voraussetzungen ist bzw. gegen oder austauschbar, allerdings nur dann, wenn eindeutig unterschiedliche Bezüge vorliegen: der Satz. Sie tranken Wein bzw. Milch ist daher nur dann korrekt, wenn eine Teilgruppe Wein, der Rest Milch trank; falls eine andere Teilgruppe etwas erst Milch, den Wein getrunken hat, muss es heißen: Sie tranken Wein oder Milch. (ENGEL 1988:741) 
Dessa forma, numa frase como Sie tranken Wein bzw. Milch, parte do grupo bebeu vinho e outra parte do grupo bebeu leite. Já o uso de oder em lugar de bzw. poderia indicar que parte do grupo bebeu vinho e depois leite. Assim, não teríamos o aspecto restritivo de $b z w$. que aponta para o fato de que parte do grupo bebeu apenas vinho e parte bebeu apenas leite. (idem)

A Grammatik der Deutschen Sprache (ZIFONUN et.al. 1997:2427) também remete à diferença entre oder e bzw., porém, detalhando-a e complementando-a:

Morfemas, palavras, frases, grupos de palavras sentenças e características mínimas comunicativas são relacionadas com a conjunção beziehungsweise, e ela é - como oder - colocada na posição entre os elementos. Ela se diferencia de oder através de uma dominância do modo inclusivo sobre o exclusivo, também possível. A alternativa é estruturada, a seqüência dos elementos é ao contrário de oder - decisiva. Normalmente o peso recai sobre o segundo elemento: o segundo deve substituir o primeiro - corrigindo-o, precisando-o, introduzindo uma terminologia, de modo que uma inversão leva a um outro entendimento. ${ }^{16}$

A Duden Grammatik considera bzw. como uma conjunção tanto alternativa quanto especificativa, com os seguintes exemplos (2005: 629 e 631):

Man streitet darüber, wie stark der Mensch durch seine Kultur bzw. seine Gene bestimmt wird.

["Discute-se o quanto o homem é determinado pela sua cultura ou por seus genes." - alternativa]

Seine Kollegin, bzw. Freundin war damit einverstanden.

["Sua colega, ou melhor, namorada, concordou com isso." especificativa]

Die Tasche war weg bzw. gestohlen.

["A bolsa sumiu, ou melhor, foi roubada". - especificativa]

16 Mit dem Konjunktor beziehungsweise (bzw.) sind Morpheme, Wörter, Phrasen, Verbgruppen, Sätze und kommunikative Minimaleinheiten zu verknüpfen, und er ist - wie oder - auf die Zwischenposition festgelegt. Er unterscheidet sich von oder durch eine Dominanz der exklusiven Lesart neben der auch möglichen inklusiven. Die Alternativ ist strukturiert, die Abfolge der Konjunkte ist - anders als bei oder - entscheidend. Es wird in der Regel zugunsten des zweiten Konjunkts gewichtet: Das zweite soll das erste - korrigierend, präzisierend, terminologisierend - ersetzen, so dass eine Vertauschung zu einem anderen Verständnis führt." 
Enquanto conjunção aditiva, bzw. é apontada como sinônimo de oder ["ou"]. A mesma sinonímia é apresentada para a forma especificativa, apenas com a ressalva de que se trataria de um 'ou'explicativo (precisador)" ["explicatives, (präzisierendes) 'oder" - DUDEN 2005: 631].

O tema dos conectores alternativos e especificativos é mencionado pela Duden Grammatik na seção que trata das relações no interior do texto. À página 1088, a relação alternativa (alternative Verknüpfung) é descrita como "abrindo um campo de possibilidades igualitárias"17, cujas alternativas podem ser igualmente válidas ou excluir-se mutuamente. De acordo com a obra, a conjunção oder é geralmente usada apenas como excludente, enquanto:

Beziehungsweise desvia originariamente a relação entre alternativas para outras unidades do texto, que devem ser encaradas como paralelas, e às quais ela se refere. A seqüência do texto retrata a ordem de referência válida. Freqüentemente, porém, [...] bzw. é utilizada com a finalidade de uma precisão explicativa ${ }^{18}$. (DUDEN 2005: 1088)

Quanto à relação explicativa, ela é assim descrita:

Uma ligação explicativa (esclarecedora) existe quando o conteúdo da declaração anterior é melhor esclarecido através de outros detalhes. Conectores explicativos pressupõem a existência de uma ligação entre 0 conteúdo básico e a explicação. O leitor deve reconstruir as relações reais entre eles. (DUDEN 2006: 1108) ${ }^{19}$

Desse modo, podemos concluir que beziehungsweise é um conector que tem a finalidade de detalhar e especificar a informação de modo a deixar claro, nos contextos aplicados, que os elementos em questão se relacionam em pares, como em: Die Kandidaten kommen aus München, bzw. aus Köln, em que uma parte veio de Munique e outra parte veio de Colônia e, nesse caso, não se pode levantar a hipótese de que ambos vieram das duas cidades. Em casos em que bzw. expressa uma alternativa paralela, como em Sie tranken Wein bzw. Milch (cf. ENGEL 1988:741), somente é possível utilizar bzw. se queremos exprimir que os grupos são estanques. Caso contrário, a conjunção oder deve ser aplicada.

17 Die alternative (zur Wahl stellende) Verknüpfung eröffnet ein Feld gleichberechtigter Möglichkeiten.

18 Beziehungsweise lenkt ursprünglich das Verhältnis zwischen Alternativen auf andere parallel zu betrachten Einheiten im Text, auf die es verweist. Die Textfolge bildet die gültige Bezugsreihenfolge ab. Häufiger wird [...] bzw. aber für explikative [...] Präzisierungen genutzt. (id.)

19 Eine explikative (erklärende) Anknüpfung liegt vor, wenn der Sachverhalt der vorangehenden Aussage durch weitere Einzelheiten näher erläutert wird. Explikative Konnektoren setzen voraus, dass ein Zusammenhang zwischen dem zugrunde liegenden Sachverhalt und der Erläuterung besteht. Die tatsächlichen Bezüge muss der Leser rekonstruieren. 
Em outros contextos, bzw. indica relações de alternatividade diversas entre elementos que devem ser buscados num contexto maior ou, ainda, assume um papel de introdutor de uma explicação ou precisão da informação.

Dessa forma, não basta examinar o conector isoladamente, mas sim, é necessário considerá-lo dentro dos contextos em que está inserido. Por exemplo, a alternativa apresentada por beziehungsweise difere da alternativa apresentada por oder porque beziehungsweise contém o aspecto de precisão que oder não contém.

O quadro a seguir visa demonstrar os usos e definições de beziehungsweise apresentados nas gramáticas alemãs consultadas:

\begin{tabular}{|l|c|c|c|c|}
\hline & $\begin{array}{c}\text { Alternativo } \\
\text { inclusivo } \\
\text { restritivo } \\
\text { "e/ou" }\end{array}$ & $\begin{array}{c}\text { Alternativo } \\
\text { exclusivo } \\
\text { "ou" }\end{array}$ & $\begin{array}{c}\text { Explicativo/ } \\
\text { Especificativo } \\
\text { (spezifierend) } \\
\text { "ou melhor" }\end{array}$ & $\begin{array}{c}\text { Relação } \\
\text { biuníoca: } \\
\text { "respectiva- } \\
\text { mente" }\end{array}$ \\
\hline $\begin{array}{l}\text { Deutsche Grammatik } \\
\text { ENGEL (1988) }\end{array}$ & $\mathrm{X}$ & $\mathrm{X}$ & - & - \\
\hline $\begin{array}{l}\text { Grammatik der } \\
\text { deutschen Sprache } \\
\text { GöTZE (1992) }\end{array}$ & $\mathrm{X}$ & $\mathrm{X}$ & - & - \\
\hline $\begin{array}{l}\text { Deutsche Grammatik } \\
\text { JUNG (1990) }\end{array}$ & $\mathrm{X}$ & $\mathrm{X}$ & - & - \\
\hline $\begin{array}{l}\text { Grammatik der } \\
\text { deutschen Sprache } \\
\text { ScHULZ \& GRIESBACH } \\
\text { (1960) }\end{array}$ & $\mathrm{X}$ & $\mathrm{X}$ & $\mathrm{X}$ & - \\
\hline $\begin{array}{l}\text { DUDEN Grammatik } \\
\text { (2005) }\end{array}$ & $\mathrm{X}$ & $\mathrm{X}$ & $\mathrm{X}$ & - \\
\hline $\begin{array}{l}\text { Lexikon deutscher } \\
\text { Konjunktionen } \\
\text { BuscHA (1989) }\end{array}$ & $\mathrm{X}$ & $\mathrm{X}$ & $\mathrm{X}$ & $\mathrm{X}$ \\
\hline $\begin{array}{l}\text { Deutsche Grammatik } \\
\text { EICHLER (1986) }\end{array}$ & $\mathrm{X}$ & $\mathrm{X}$ & $\mathrm{X}$ & - \\
\hline $\begin{array}{l}\text { Lesen lehren lernen: } \\
\text { eine rezeptive } \\
\text { Grammatik des } \\
\text { Deutschen } \\
\text { HERINGER (1989) }\end{array}$ & & $\mathrm{X}$ & $\mathrm{X}$ & - \\
\hline $\begin{array}{l}\text { Grammatik der } \\
\text { deutschen Sprache } \\
\text { ZIFONUN (1997) }\end{array}$ & & $\mathrm{X}$ & & \\
\hline
\end{tabular}


Portanto, após o levantamento das obras sobre o assunto, a definição do LANGENSCHEIDT Großwörterbuch Deutsch als Fremdsprache (2003: 172) mostrou-se mais interessante para a presente pesquisa, ao detalhar as três possibilidades de uso de bzw.:

1. expressa que duas afirmações diferentes se aplicam a dois elementos distintos,

2. é utilizada para especificação da informação,

3. indica alternatividade.

Estas três possibilidades de uso constituem a base para a análise dos dados empíricos do corpus da pesquisa, cuja constituição é apresentada no próximo item. 


\section{Corpus e Metodologia}

A fim de selecionar e analisar ocorrências da conjunção beziehungsweise em língua alemã, optei pela montagem um corpus de língua escrita. Trata-se de uma amostragem com exemplos autênticos em língua alemã retirados do site Wortschatz da Universidade de Leipzig. Alemanha, sendo composto, em sua grande maioria, de exemplos provenientes da revista alemã Der Spiegel.

Baseei-me na definição e teoria de SARDINHA (2004:17) que afirma que “(...) corpus é um artefato produzido para a pesquisa. Assim, embora textos devam ser naturais (autênticos e independentes do corpus), o corpus em si é artificial, um objeto criado com fins de pesquisa."

O ponto de partida para a seleção de exemplos autênticos foi o banco de dados do site de busca da Universidade de Leipzig, Alemanha, (http://www.wortschatz.uni-leipzig.de), que contém textos escritos retirados de diversos jornais e revistas alemãs, oferecendo exemplos de uso da palavra beziehungsweise em diversos contextos. Trata-se de um volumoso banco de dados de palavras, com cerca de 35 milhões de frases e quinhentos milhões de palavras, podendo-se consultar mais de 9 milhões de palavras e grupos de palavras diferentes.

Trata-se de um corpus contemporâneo, compreendendo exemplos a partir de 1998, que sempre está em expansão. A listagem de exemplos não está classificada por ano de ocorrências, de modo que entendo o período de 1998 a março de 2007 como espaço de busca de exemplos para a montagem de corpus da minha dissertação.

Quanto à tipologia do corpus, seguindo os preceitos de SARDINHA (2004:20), classifico o corpus dessa dissertação da seguinte maneira:

1. o modo é escrito, já que se baseia apenas em língua escrita;

2. é contemporâneo, já que representa o período de tempo corrente;

3. é de língua nativa, já que os textos são de língua alemã.

Para a constituição do corpus da pesquisa foi realizado um levantamento de todos os exemplos de beziehungsweise (por extenso e abreviado) 
constantes do site Wortschatz no dia 23 de março de 2007, desconsiderandose as ocorrências duplicadas, num total de 493 ocorrências. A maior parte das ocorrências encontradas (57\%) provém de matérias jornalísticas da revista Der Spiegel.

Em seguida, foram selecionadas as ocorrências que apresentavam um contexto suficiente para a identificação do uso de bzw., chegando-se assim a um total de 104 ocorrências, as quais foram então traduzidas por mim para 0 português e as traduções submetidas à revisão de uma tradutora profissional, para assegurar a sua adequação.

As ocorrências assim traduzidas foram então analisadas e agrupadas segundo as três possibilidades de uso de bzw. identificadas na fundamentação teórica. 


\section{Análise das ocorrências do corpus}

A análise das ocorrências do corpus permitiu a definição das seguintes traduções possíveis de bzw. para o português:
a) e
b) ou
c) respectivamente
d) ou melhor
e) e/ou
f) ou seja
g) mais precisamente
h) ou ainda

A distribuição das traduções possíveis é a seguinte:

\begin{tabular}{|l|c|c|}
\hline \multicolumn{1}{|c|}{ Tradução } & Número de ocorrências & Porcentagem \\
\hline e & 31 & $30 \%$ \\
\hline ou & 23 & $22 \%$ \\
\hline respectivamente & 18 & $17 \%$ \\
\hline ou melhor & 17 & $16 \%$ \\
\hline e/ou & 7 & $7 \%$ \\
\hline ou seja & 4 & $4 \%$ \\
\hline mais precisamente & 3 & $3 \%$ \\
\hline ou ainda & 1 & $1 \%$ \\
\hline
\end{tabular}

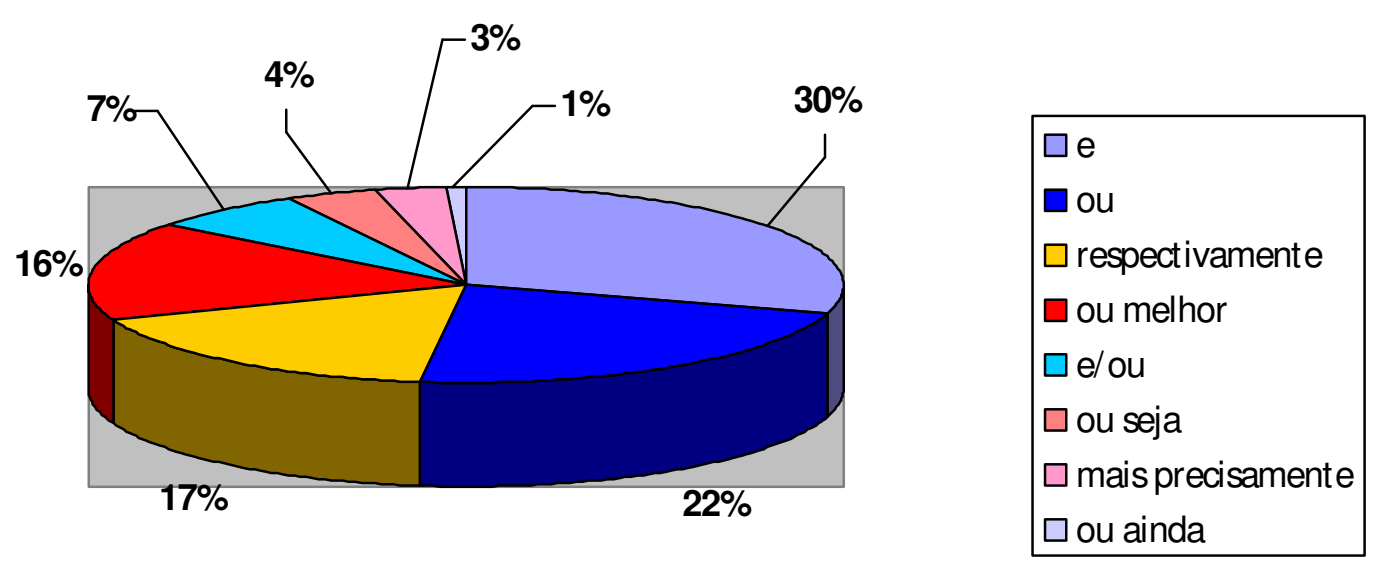


De acordo com os dados do corpus, pode-se dizer que a conjunção bzw. ocorre com mais freqüência em contextos nos quais seria usada, em português, a conjunção "e", com $30 \%$ ou seja, quase um terço das ocorrências. Seguem-se contextos nos quais seria utilizada a conjunção "ou", com $23 \%$ das ocorrências e "respectivamente" com 17\%.

O cruzamento das possibilidades de tradução com os três tipos de uso de bzw. definidos anteriormente gera o seguinte quadro:

\begin{tabular}{|l|c|}
\hline Tipo A - Relação biunívoca & respectivamente, $e$ \\
\hline Tipo B - Precisão da informação & ou melhor, ou seja, mais precisamente \\
\hline Tipo C - Alternatividade & ou, e, e/ou \\
\hline
\end{tabular}

Desse modo, tem-se a seguinte distribuição da freqüência por tipo de uso:

\begin{tabular}{|c|c|c|}
\hline Tipo & Nr. de ocorrências & Porcentagem \\
\hline A & 18 & $17 \%$ \\
\hline B & 25 & $24 \%$ \\
\hline C & 61 & $59 \%$ \\
\hline
\end{tabular}

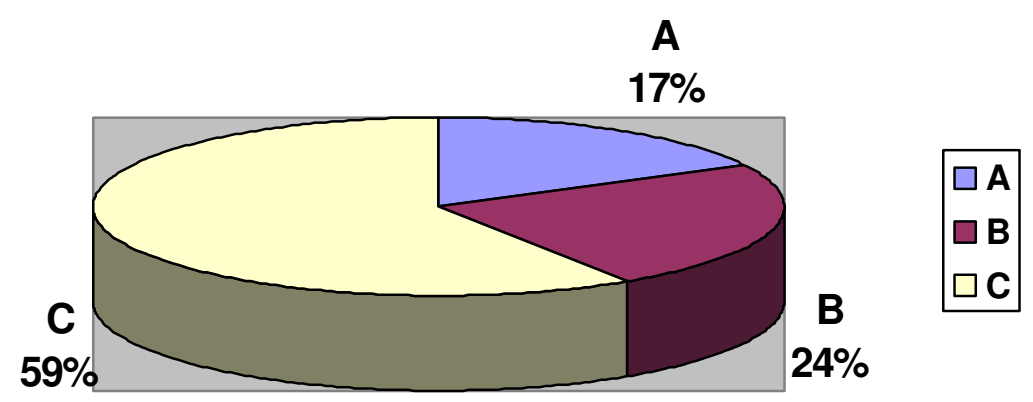

O gráfico mostra claramente que o tipo de uso A (relação biunívoca), que corresponde em português à tradução "respectivamente" e que é apresentado pelos dicionários bilíngües como o significado de bzw. por excelência, na verdade é o tipo com menor freqüência de uso no corpus. No entanto, é o grupo mais homogêneo em termos de tradução, sendo que apenas uma ocorrência do corpus não foi traduzida para o português como 
"respectivamente".

O tipo com segunda maior freqüência de uso é o tipo B (precisão da informação), com significantes $24 \%$ do total, o que mostra que bzw. é, no alemão contemporâneo, usado com muita freqüência com um caráter explicativo. Neste tipo, a tradução "ou melhor" se apresenta como a forma prototípica.

O tipo de maior ocorrência é o tipo $C$, no qual é expressa exatamente a alternatividade nas relações estabelecidas entre os elementos unidos por bzw.

A seguir, apresento as ocorrências de beziehungsweise no corpus da pesquisa, organizadas segundo as suas traduções em português e os três tipos de usos definidos, bem como comentários gerais sobre cada possibilidade de tradução.

\subsection{Análise das ocorrências por tipo de uso e tradução para o português}

\subsubsection{Tipo A - duas informações correspondem biunivocamente a duas outras}

Neste uso, bzw. une quatro elementos através de uma relação biunívoca, que pode ser representada como "AaBb". Os dois elementos principais, aos quais os demais se relacionam, possuem sempre algum traço semântico em comum ou pertencem a uma mesma categoria, como mostram os exemplos do corpus.

A imensa maioria das ocorrências deste tipo no corpus refere-se a valores numéricos, absolutos ou em porcentagem (apenas duas ocorrências em dezessete - A5 e A10 - não apresentam números). Nota-se uma tendência em apresentar o valor numérico menor primeiro, seguido do valor maior.

A relação "AaBb" explicitada pelo uso de beziehungsweise não deixa dúvidas sobre a distribuição e não dá margem a interpretações dúbias, deixando claras as relações de cada elemento dentro do grupo maior sob consideração.

Em 17 das 18 ocorrências, a conjunção bzw. foi traduzida em português 
como "respectivamente". No único caso de tradução diferente (ocorrência A1), foi utilizada a conjunção "e". Nesta ocorrência, temos os nomes de duas pessoas e seus respectivos e-mails:

A1. Das Land zwischen dem Jordan und dem Mittelmeer gehöre nicht allein den Israelis. Es sollte "in einen israelischen und einen palästinensischen Staat" aufgeteilt werden. Man müsse klarstellen, dass "wir keine Fremden sind, sondern dem Nahen Osten angehören". Ein Sturz der Palästinenserbehörde wäre seiner Ansicht nach ein Fehler, es würde die Israelis nur "zurückwerfen und Chaos schaffen". Michael: "Wenn am Ende ein unabhängiger palästinensischer Staat entstehen wird, so wird sein natürlicher Verbündeter nur Israel sein können." Für Rückfragen stehen Ihnen Elke Bunse oder Verena Schröder, ZEIT-Presse- und Öffentlichkeitsarbeit, (Tel.: 040/ 3280217, Fax: 040/3280-558, e-mail: bunse@zeit.de bzw. schroeder@zeit.de) gern zur Verfügung. (http://zeus.zeit.de/text/archiv/ 2002/07/200207_pressemeldungsdummy. xml - anexado em 12/06/2007)
A1. A terra entre o Jordão e o Mar Mediterrâneo não pertence apenas a Israel. Deveria ser dividida "em um Estado israelense e um palestino". É preciso esclarecer "que não somos estrangeiros, apenas pertencemos ao Oriente Próximo". $\mathrm{Na}$ sua opinião, a queda da Autoridade Palestina seria um erro, iria apenas "repelir" os israelenses "e produzir caos". Michael:

Se acabar surgindo um Estado palestino autônomo, seu aliado natural só poderá ser Israel." Para mais informações, encontram-se à disposição Elke Bunse ou Verena Schröder, ZEIT- imprensa e relações públicas, (Tel.: 040/ 3280-217, Fax: 040/3280-558, e-mail: bunse@zeit.de $\underline{\boldsymbol{e}}$ schroeder@zeit.de).

A partir do contexto, deduz-se que é possível contatar qualquer um dos dois endereços indiferentemente para obter as informações necessárias. Os endereços de e-mail deixam claro as relações entre eles e os nomes mencionados anteriormente. Desse modo, não é extremamente necessário marcar a correspondência entre os endereços e seus donos, o que permite 0 uso da conjunção "e". Além disso, os endereços se encontram entre parênteses, juntamente com outras informações comuns às pessoas mencionadas, e relativamente longe de seus referentes, o que provavelmente contribuiu para que se evitasse o uso de "respectivamente".

Todas as demais ocorrências neste tipo de uso foram traduzidas por "respectivamente" e parece não haver dificuldades de tradução ou interpretação de bzw. neste contexto específico. 


\begin{tabular}{|c|c|}
\hline $\begin{array}{l}\text { A2.Der erste Ökumenische Kirchentag } \\
\text { findet vom 28. Mai bis zum 1. Juni statt. } \\
\text { Der Eröffnungsgottesdienst wird am } \\
\text { Brandenburger Tor abgehalten, am } \\
\text { Mittwoch, dem 28. Mai um 18 Uhr. } \\
\text { Anschließend laden die Kirchen unter dem } \\
\text { Motto ,Durchgehend (h)offen“ zu einem } \\
\text { Straßenfest ein, das sich Unter den Linden } \\
\text { bis zum Schlossplatz und um den } \\
\text { Gendarmenmarkt erstrecken wird. Eine } \\
\text { Dauerkarte für den Kirchentag kostet } 79 \\
\text { Euro, eine Tageskarte } 23 \text { Euro (ermäßigt } 48 \\
\text { bzw. 13 Euro). } \\
\text { (http://www.tagesspiegel.de/berlin/;art270,2 }\end{array}$ & $\begin{array}{l}\text { A2. O primeiro encontro ecumênico ocorre } \\
\text { de } 28 \text { de maio a } 1^{\circ} \text {. de junho. A missa de } \\
\text { abertura será realizada no Portão de } \\
\text { Brandemburgo, na quarta-feira, dia } 28 \text { de } \\
\text { maio, às } 18 \mathrm{~h} \text {. } \\
\text { Em seguida, as igrejas convidam para uma } \\
\text { festa de rua com o lema } \\
\text { "esperança/abertura contínua", que se } \\
\text { estende de Unter den Linden até } \\
\text { Schlossplatz e pelo Gendarmenmarkt. } \\
\text { Um bilhete para o evento todo custa } 79 \\
\text { euros, para um único dia, } 23 \text { euros (com } \\
\text { desconto, } 48 \text { e } 13 \text { euros, respectivamente). }\end{array}$ \\
\hline
\end{tabular}

A3. Bezogen auf die Zahl der Schüler hatte Berlin 2001 nach einer Statistik der Kultusministerkonferenz 14 Prozent mehr Lehrer als der Bundesdurchschnitt. In Berlin kamen 15,4 Schüler auf eine Vollzeitlehrer-Einheit, in den PisaSpitzenländern Bayern und BadenWürttemberg waren es dagegen 18 bzw. 17 Schüler. (http://www.tagesspiegel.de/berlin/;art270, 2194278 - Anexado em 06/06/2007)
A3. Em relação ao número de alunos, Berlim tinha em 2001, segundo estatística da conferência do ministério da cultura, $14 \%$ mais professores do que a média do país. Em Berlim, havia um professor em tempo integral para cada 15,4 alunos; por outro lado, na Baviera e em Baden-

Württemberg, estados que se destacam no PISA*, o número de alunos era 18 e 17, respectivamente.

*PISA = Programa Internacional de Avaliação de Alunos
A4. Gut jeder Dritte (36 Prozent) bescheinigt der CDU/CSU, sie würde ihre Rolle als Opposition in befriedigender Weise ausfuillen, 60 Prozent sind aber mit der Arbeit der Union weniger (37 Prozent) oder gar nicht (23

Prozent) einverstanden. Die Mehrheit von 66 Prozent der eigenen Anhänger hat an der Politik ihrer Partei nichts Wesentliches auszusetzen, mit 32 Prozent stellen die Kritiker aber auch hier eine nicht unbedeutende Gruppe dar.

Bemerkenswert ist dabei, dass die Nichtwähler und Unentschlossenen weithin, zu 82 bzw. 75 Prozent, mit dem Kurs der CDU/CSUOpposition unzufrieden sind. (http://www.tagesspiegel.de/politik/;art771,197 8291 - Anexado em 06/06/2007)
A4. Uma em cada três pessoas (36\%) afirma que o CDU/CSU estaria exercendo seu papel como oposição de maneira satisfatória, $60 \%$, porém, aprovam menos (37\%) ou desaprovam totalmente $(23 \%)$ o trabalho da União Cristã. A maioria, 66\% dos próprios partidários, não tem nenhuma crítica substancial à política de seu partido, mas os críticos, com $32 \%$, tampouco constituem um grupo inexpressivo.

É digno de nota o fato de os não-eleitores e indecisos, $82 \%$ e $75 \%$ respectivamente, estarem insatisfeitos com o rumo da oposição feita pelo CDU/CSU. 
A5. In dieser Beurteilung des an sich Guten und Bösen, zum Unterschiede von dem, was nur beziehungsweise auf Wohl oder Übel so genannt werden kann, kommt es auf folgende Punkte an.

Entweder ein Vernunftprinzip wird schon an sich als der Bestimmungsgrund des Willens gedacht, ohne Rücksicht auf mögliche Objekte des

Begehrungsvermögens, (also bloß durch die gesetzliche Form der Maxime,) alsdann ist jenes Prinzip praktisches Gesetz a priori, und reine Vernunft wird für sich praktisch zu sein angenommen. (http://gutenberg.spiegel.de/kant/kritikpr/ krt11211.htm - Anexado em 31/05/2007)
A5. Nesse julgamento do Bem (Guten) e do Mal (Bösen) em si em contraste com o que somente pode ser chamado, respectivamente, de Bondade (Wohl) ou Maldade (Übel), chega-se aos seguintes pontos: ou um princípio racional em si já é considerado motivo determinante da vontade, sem relação com possíveis objetos da faculdade de desejar (portanto, meramente através da forma de lei da máxima), e então esse princípio é lei prática a priori e supõe-se que a razão pura seja prática por si mesma.
A6. Die Automobilindustrie kam der Studie zufolge insgesamt auf die grösste Qualitätssteigerung seit 1997. Vor allem Toyota und GM hätten in den vergangenen fünf Jahren

Qualitätsverbesserungen von insgesamt 31 beziehungsweise 30 Prozent erzielt, hiess es. «Das zeigt eine konzertierte Anstrengung nicht nur bei GM, sondern der gesamten Industrie, die Qualität zu verbessern», sagte Brian Walters, Direktor für Produktforschung bei J.D. Power.

Quelle: Tagesanzeiger (http://www.ftor.de/board/showpost.php? $\mathrm{p}=185014 \& p o$ stcount=20 - Anexado em 01/06/2007)
A6. Segundo o estudo, a indústria automobilística como um todo atingiu o máximo em qualidade a partir de 1997. Dizia que sobretudo a Toyota e a GM teriam alcançado, nos cinco anos anteriores, aperfeiçoamentos qualitativos que totalizaram, respectivamente, $31 \% \mathrm{e}$ $30 \%$. "Isso mostra um esforço combinado não apenas da GM, mas de toda a indústria para melhorar a qualidade", disse Brian Walters, diretor de pesquisa de produção da J. D. Power.
A7. Schlimmer noch: Positive Empfehlungen auszusprechen, die beobachteten Firmen zu beraten oder bei den Firmen für neue

Bankdienstleistungen Werbung zu machen, brachte den Merrill-LynchAnalysten Gehaltserhöhungen ein. Nach Erkenntnissen der Ermittler stieg das Jahreseinkommen des Teamchefs Henry Blodget von 1999 bis 2001 von drei auf zwölf Millionen Dollar an. Blogdet tat etwas für sein Geld: Den Fernsehsendern CNN und CNBC gab er in den Jahren 1999 und 200046 beziehungsweise 77
A7. Pior ainda: proferir recomendações positivas, aconselhar as firmas observadas ou fazer propaganda junto a elas de novos serviços bancários rendia aos analistas da Merrill-Lynch aumentos salariais. Conforme constataram os investigadores, o rendimento anual do chefe da equipe, Henry Blodget, aumentou entre 1999 e 2001 de três para doze milhões de dólares. Blodget fazia jus ao seu dinheiro: nos anos de 1999 e 2000, concedeu às emissoras de TV CNN e CNBC 46 e 77 entrevistas, respectivamente, como "analista objetivo" da maior empresa de Wall Street. 


\section{Interviews als "objektiver Analyst" des größten Wall-Street-Hauses. (http://www.stock-channel.net/stock- board/showthread.php3?t=7538\&page $=8$ $\& p p=15$ - Anexado em 01/06/2007)}

A8. Das Kunstzentrum soll zum 1. Januar 2003 als Aufführungsort geschlossen werden, damit würde auch das artist-inresidence-Programm eingestellt. Die Kunst-Werke und das Künstlerhaus Bethanien müssen Kürzungen um 20 beziehungsweise 17 Prozent hinnehmen. Die Sparpolitik des Senats richte sich damit gegen junge Einrichtungen, deren Programmpolitik gerade zu blühen beginne, erklärte Wilhelm Großmann, Geschäftsführer des Podewil. (http://www.tagesspiegel.de/kultur/archiv/ 26.03.2002/ak-ku-445311.html - Anexado em 01/06/2007)

A9. Von der langfristig wirkenden politischen Stimmung profitiert weiter vor allem die Union. In der zweiten Umfrage im März liegt sie hier wieder deutlich vor der SPD, allerdings hat sich ihr Vorsprung seit Anfang des Monats etwas verkleinert. Die CDU/CSU erreicht jetzt 41 Prozent (Anfang März 45 Prozent), die SPD kommt unverändert auf 35 Prozent. Grüne und FDP konnten ihr Ergebnis um jeweils zwei Prozentpunkte auf acht beziehungsweise neun Prozent verbessern. Die PDS erreicht fünf Prozent (Anfang März vier Prozent). (http://www.tagesspiegel.de/politik/archiv/ 22.03.2002/ak-po-in-4412472.html Anexado em 01/06/2007)
A8. O centro de artes como local de encenação deve ser fechado em $1^{\circ}$. de janeiro de 2003, com isso seria encerrado também o programa Artist-in-residence. Kunst-Werke e Künstlerhaus Bethanien devem se conformar a cortes de $20 \%$ e $17 \%$, respectivamente. Assim, a política de contenção do senado estaria se voltando contra instituições jovens cujo plano de ação começa a dar frutos agora, conforme declarou Wilhelm Großmann, administrador do Podewil.

\section{A10. Knie-" beziehungsweise \\ "Wirbelsäulenspezialist" dürfen sich die Münchener Orthopäden Jürgen Toft und Thomas Hoogland seit dem 8. Januar 2002 nennen. An diesem Tag fällte das Bundesverfassungsgericht eine entsprechende Entscheidung, die dem Laien unspektakulär erscheinen mag, für die Ärzteschaft aber einer kleinen}

A9. Com o ambiente político vigente a longo prazo continua lucrando sobretudo a União Cristã. Na segunda pesquisa de opinião, em março, ela mais uma vez fica claramente à frente do SPD; no entanto, desde o começo do mês sua vantagem diminuiu um pouco. $\mathrm{O} \mathrm{CDU} / \mathrm{CSU}$ atinge agora $41 \%$ (início de março $45 \%$ ), o SPD permanece em $35 \%$. O Partido Verde e o FDP conseguiram melhorar seus resultados em dois pontos percentuais cada, passando para $8 \%$ e $9 \%$, respectivamente. O PDS alcança 5\% (início de março 4\%).
A10. Os ortopedistas de Munique Jürgen Toft e Thomas Hoogland podem se intitular especialistas de joelho e de coluna vertebral, respectivamente, desde 8 de janeiro de 2002. Nesta data, o Tribunal Constitucional Federal tomou uma decisão pertinente que pode não parecer espetacular para o leigo, mas que para a classe médica se equipara a uma pequena revolução. 
Revolution gleichkommt.

(http://www.tagesspiegel.de/wirtschaft/arch

iv/01.03.2002/ak-wi-ve-5511149.html -

Anexado em 03/06/2007)

A11. Wahrscheinlich wird sich das Drama im Dschungel noch schneller zuspitzen: Bis vor kurzem galt der Verlust von

Lebensraum und Nahrungsquellen durch

Ausweitung der menschlichen Zivilisation

als Hauptursache des Affensterbens. An

diese wirtschaftliche Krise hatten sich die

Waldbewohner erstaunlich gut angepasst:

Sie zogen sich in weiter abgelegene

Gegenden zurück und gewöhnten sich

daran, mit weniger Lebensraum

auszukommen. Artenschützer gingen

deshalb bis vor kurzem davon aus, dass in

der Republik Kongo und Gabun, zu 60

beziehungsweise 80 Prozent mit

unberührtem Urwald bedeckt, halbwegs

stabile Affenpopulationen leben.

(http://www.tagesspiegel.de/meinung/archi

v/09.04.2003/518206.asp - Anexado em

03/06/2007)

A11. Talvez o drama na selva se agrave

ainda mais rapidamente: até pouco tempo, a perda do espaço vital e das fontes de alimentação devido ao crescimento da civilização humana era considerada a principal causa da morte dos macacos. Os moradores da floresta tinham se adaptado a essa crise econômica surpreendentemente bem: eles se retiraram para regiões mais afastadas e se acostumaram a viver com menos espaço vital. Por isso, protetores de espécies animais supunham até pouco tempo que na República do Congo e em Gabão, respectivamente com $60 \%$ e $80 \%$ de selva intocada, vivessem populações de macacos mais ou menos estáveis.

A12. "Zum Glück ist niemand gestorben" Botschafter Titorenko hatte am Morgen die Botschaft in Bagdad in Begleitung verlassen. Bei zwei Angriffen acht beziehungsweise 15 Kilometer von der Stadtgrenze entfernt seien jeweils mehrere Personen aus der Gruppe verletzt worden, sagte der Augenzeuge. (http://rheinzeitung.de/on/03/04/06/topnews/irakuss.html - Anexado em 03/06/2007)
A12. "Felizmente ninguém morreu". O embaixador Titorenko havia deixado a embaixada em Bagdá pela manhã acompanhado.

Segundo testemunha ocular, em dois ataques, respectivamente a 8 e 15 quilômetros da fronteira, várias pessoas do grupo teriam sido feridas.
A13. Snowtropolis ist täglich von 10 bis 24 Uhr geöffnet. Letzter Einlass ist 23 Uhr. Eine Stunde auf der Piste kostet für Erwachsene montags bis donnerstags 8 Euro, freitags, sonnabends und sonntags 10 Euro. Kinder und Jugendliche bis 17 Jahre zahlen 6 beziehungsweise 8 Euro.

(http://www.tagesspiegel.de/brandenburg/a rchiv/23.03.2003/493198.asp - Anexado em 03/06/2007)
A13. Snowtropolis está aberta diariamente das $10 \mathrm{~h}$ às $24 \mathrm{~h}$. A última admissão é às 23h. Uma hora na pista, de segunda a quinta-feira, custa para adultos 8 euros; às sextas, sábados e domingos, 10 euros.

Crianças e jovens até 17 anos pagam 6 e 8 euros, respectivamente. 
A14. Der Eintrittspreis für die Cebit beträgt im Vorverkauf 31 Euro für die Tageskarte, die Dauerkarte kostet 68 Euro. An der Tageskasse werden 35 Euro beziehungsweise 78 Euro verlangt. Ermäßigungen gibt es für Schüler, Studenten, Wehrpflichtige und Zivildienstleistende für 16 Euro. (http://archiv.tagesspiegel.de/archiv/12.03. 2003/474993.asp_ Anexado em 03/06/2007)
A14. O ingresso para a Cebit custa, se adquirido antecipadamente, 31 euros para um único dia e 68 euros para o evento todo. $\mathrm{Na}$ bilheteria, sai por 35 euros e 78 euros, respectivamente.

Há um desconto de 16 euros para estudantes, indivíduos que estejam prestando serviço militar e serviço social civil.

A15. Zum Projekt gehören auch ein Hotel und ein Restaurant im so genannten Gotischen Saal. Zwei Veranstaltungsräume in den denkmalgeschützten Altbauten bieten Platz für 100 beziehungsweise 400 Personen. Damit ist der erste Bauabschnitt des Projekts fertiggestellt. (http://www.tagesspiegel.de/berlin/archiv/2 5.02.2003/453367.asp - Anexado em $05 / 06 / 2007)$

A16. Die Katastrophe von Seveso beschäftigte Hoffmann-La Roche lange Zeit. Der Konzern wandte nach eigenen Angaben mehr als 300 Millionen Franken (360 Millionen Mark) unter anderem für Entschädigungszahlungen, Prozesskosten und die Abtragung kontaminierter Erde auf. Zwei Manager wurden von einem italienischen Gericht zu zwei

beziehungsweise eineinhalb Jahren Haft verurteilt. (http://www.bvbbev.de/html/die_dioxin-cosaostra.html Anexado em 05/06/2007)
A15. Ao projeto pertencem também um hotel e um restaurante no assim chamado Salão Gótico. Duas salas para eventos nas construções antigas tombadas pelo patrimônio oferecem lugares para $100 \mathrm{e}$ 400 pessoas, respectivamente. Com isso, conclui-se a primeira etapa de construção do projeto.

\footnotetext{
A17. Los Angeles - Britney Spears und ihr Vorbild Madonna haben beste Chancen auf eine Goldene Himbeere als schlechteste Schauspielerin des Jahres. (fest/sda) Sie führen die Liste der berüchtigten Himbeeren-Nominierungen mit acht beziehungsweise sieben Anwartschaften in verschiedenen Kategorien an. (http://www.news.ch/Britney+Spears+und+ Madonna+fuer+Hollywood+Spottpreise+n

A17. Los Angeles - Britney Spears e seu ídolo Madonna têm grandes chances de ganhar a Framboesa de Ouro como pior atriz do ano. (fest/sda) Elas lideram a lista das famigeradas indicações ao prêmio com, respectivamente, 8 e 7 indicações em diferentes categorias.
}

A16. A catástrofe de Seveso ocupou Hoffmann-La Roche por muito tempo. O grupo de empresas gastou, segundo informações próprias, mais de 300 milhões de francos (360 milhões de marcos) com pagamento de indenizações, custas processuais e remoção da terra contaminada, entre outras coisas. Dois gerentes foram condenados por um tribunal italiano à reclusão de 1 ano e meio e 2 anos, respectivamente. 
ominiert/131402/detail.htm - Anexado em

05/06/2007)

A18. SPD und Grüne kommen damit zusammen auf 45 Prozent der Stimmen, während auf Union und FDP 48 Prozent entfallen, wäre an diesem Sonntag Bundestagswahl. Nach einer Erhebung von Emnid für den Nachrichtensender n-tv behauptete die Union mit 40 Prozent ihren Sechs-Punkte-Abstand zur SPD. Doch konnten die Sozialdemokraten auch in dieser Umfrage durch ihren Einsatz bei der Hochwasserkatastrophe punkten. Laut Politbarometer erhalten Grüne und FDP unverändert sieben beziehungsweise neun Prozent der Wählerstimmen. (http://www.morgenpost.de/content/2002/0 8/24/politik/544078.html _ Anexado em 05/06/2007)
A18. O SPD e o Partido Verde juntos concentrariam $45 \%$ dos votos enquanto a União e o FDP ficariam com $48 \%$, se a eleição para o Parlamento Federal fosse nesse domingo. Conforme pesquisa do Emnid para a emissora de notícias n-tv, com $40 \%$ a União garantiu seus seis pontos de diferença em relação ao SPD. Nesta pesquisa, os sociais-democratas também ganharam pontos por sua mobilização diante da catástrofe da inundação. Segundo o termômetro político, o Partido Verde e o FDP continuam inalterados com $7 \%$ e $9 \%$ das intenções de voto, respectivamente.

\subsubsection{Tipo B: especificação/precisão da informação}

O uso de beziehungsweise como correção de informação implica um detalhamento de algo já mencionado, assumindo um papel metalingüístico e precisando a informação. Isto se dá através do acréscimo de uma informação que especifica ou explica uma primeira, de modo que, neste tipo de uso, não há mais quatro elementos a serem unidos biunivocamente, mas sim dois elementos que são colocados em uma relação de equivalência, mantendo no entanto, como verificado na revisão da literatura, um destaque maior dado ao segundo elemento apresentado.

A relação que se estabelece entre esses elementos não é aleatória. Nas ocorrências analisadas, observa-se um jogo entre domínios maiores e menores, aos quais os elementos estão subordinados. Assim, um determinado micro-cosmo $\mathrm{A}$ é representado dentro de um macro-cosmo $\mathrm{B}$ e corresponde à precisão da informação dada através da metalinguagem. Entretanto, o movimento inverso também é possível, ou seja, parte-se de um microcosmo $\mathrm{A}$ 
e expande-se a informação para um macrocosmo B, ou ainda pode-se colocar dois universos lado a lado e estabelecer uma relação de similaridade entre eles.

Dessa forma, podemos constatar três tipos de organização dos domínios representados:

a) O elemento B está contido no elemento $A(B \subset A=A=$ macrocosmo e $\mathrm{B}=$ microcosmo)

Este grupo apresenta um movimento de "precisão da informação" ou restrição do foco, partindo do termo mais geral e focalizando um exemplo específico dentro do mesmo. Alguns exemplos são: o castelo Plaue, que fica no estado de Brandenburgo (B10); os "eleitores" pertencentes ao grupo de "cidadãos" (B16), "Berlim" como parte do "país" (B22) e os "centros de aperfeiçoamento" mantidos pelos "sindicatos" (B23)

Nestes casos há uma restrição da informação explicitada pelo microcosmo referente ao macrocosmo. O microcosmo é destacado pelo uso de beziehungsweise, de modo que a informação explicitada por ele representa uma precisão da informação em relação ao primeiro elemento. O uso de bzw. aqui indica uma explicitação mais detalhada, um acréscimo de informação. Há um destaque para o segundo elemento, que tem um papel determinante em esclarecer e precisar a informação em questão.

Este grupo abrange as ocorrências B7, B9, B10, B13, B16, B17, B18, B21, B22 e B23.

b) O elemento $B$ contém o elemento $A(B \supset A=>A=$ microcosmo e $B=$ macrocosmo)

Neste grupo, ao contrário do anterior, há uma "expansão/adição de informação" ou abertura do foco, na qual bzw. estabelece a relação entre um elemento particular e o todo no qual ele se encaixa. Nesses casos, temos um processo em que o microcosmo se abre a um macrocosmo, de modo que a informação adicionada não é essencial para o entendimento do enunciado, mas a complementa e aponta para uma questão mais abrangente. A nova 
informação não possui um peso tão decisivo em termos de importância quando comparada ao caso anterior, em que beziehungsweise expressa uma restrição da informação em questão.

Desse modo, este uso de beziehungsweise indica uma correção e expansão da informação ampliando seu foco, já que não restringe a informação inicial, mas sim adiciona mais dados. Como exemplos, podemos citar a "Rússia" como parte da "antiga União Soviética" (B2); "evento" como parte de "treinamento" (B8); a tipografia Brockhaus que está dentro da editora Brockhaus (B11); a política industrial como parte da intervenção do governo (B15).

A este grupo pertencem os exemplos B2, B4, B5, B6, B8, B11, B12, B14, B15, B20 e B25.

c) $O$ elemento $B$ corresponde ao elemento $A(A \cong B \Rightarrow A$ e $B$ são equivalentes)

Neste terceiro grupo, bzw. não estabelece relações especificamente entre um macro e um microcosmo, mas sim entre elementos de dois universos distintos que são apresentados como equivalentes. Compõem este grupo as ocorrências B1, B3, B19 e B24. Em B1, os inimigos de Stölzl são apresentados também como inimigos de Steffel; em B3, Bismark e Kohl são apresentados como equivalentes, cada um em sua época; em B19, o mesmo valor é apresentado como porcentagem (15\%) e em termos absolutos (1700 euros). Finalmente, em B24, "executados" e "assassinados" são colocados como sinônimos, na situação em questão.

A distribuição das ocorrências por subtipo apresenta a seguinte configuração:

\begin{tabular}{|c|c|c|}
\hline Subtipo & Ocorrências & Porcentagem \\
\hline $\mathrm{a}(\mathrm{B} \subset \mathrm{A})$ & 10 & $40 \%$ \\
\hline $\mathrm{b}(\mathrm{B} \supset \mathrm{A})$ & 11 & $44 \%$ \\
\hline $\mathrm{c}(\mathrm{B} \cong \mathrm{A})$ & 4 & $16 \%$ \\
\hline
\end{tabular}

Nota-se que tanto a expansão como a restrição da informação se 
apresentam equilibradas, sendo o terceiro tipo bem menos freqüente, mas ainda representativo.

No que se refere às traduções para o português, a conjunção $b z w$. foi traduzida neste tipo de uso como "ou melhor" (68\%), " ou seja" (16\%), "mais precisamente" (12\%) e "melhor ainda" (4\%). Assim, pode-se afirmar que "ou melhor" é a forma mais freqüente de tradução desse tipo de uso de bzw. para o português.

Detalhando-se as possibilidades pelos três subtipos, observa-se 0 seguinte:

\begin{tabular}{|c|c|c|c|c|c|c|}
\hline & \multicolumn{2}{|c|}{ Subtipo a } & \multicolumn{2}{c|}{ Subtipo b } & \multicolumn{2}{c|}{ Subtipo c } \\
\hline & Ocor. & $\%$ & Ocor. & $\%$ & Ocor. & $\%$ \\
\hline ou melhor & 7 & 64 & 9 & 82 & 2 & 50 \\
\hline ou seja & 2 & 18 & 1 & 9 & 1 & 25 \\
\hline $\begin{array}{c}\text { mais } \\
\text { precisamente }\end{array}$ & 2 & 18 & - & - & 1 & 25 \\
\hline melhor ainda & - & - & 1 & 9 & - & - \\
\hline
\end{tabular}

"Ou melhor" continua sendo a tradução preferida em todos os subtipos, sendo especialmente representativa do subtipo b (expansão da informação). A tradução " ou seja", por outro lado, é pouco representada nesse subtipo, sendo mais freqüente no subtipo a (precisão da informação), contudo, com a mesma freqüência da tradução "mais precisamente". As poucas ocorrências do subtipo c não permitem maiores observações além da predominância de "ou melhor". A forma "melhor ainda" ocorre apenas uma vez e pode ser considerada uma variação enfática de "ou melhor".

Em relação à tradução de beziehungsweise para o português como "ou seja" há uma precisão e detalhamento da informação muito mais forte do que "ou melhor", o que explica sua freqüência no subtipo de precisão da informação. O mesmo acontece com "mais precisamente", que na verdade explicita o movimento de restrição do foco da informação. Em todos esses casos há uma restrição da informação e não adição. 
A seguir, são apresentadas as ocorrências deste tipo de uso presentes no corpus, organizadas de acordo com sua tradução para o português.

\section{B1. Einem anderen Parteifreund kam gestern in Erinnerung, dass Stölzl es vor einem Jahr nicht geschafft hatte, ein Führungsteam zu formen und bei der Vorstandswahl durchzudrücken. Jetzt werde voraussichtlich wieder ein Vorstand gewählt, in dem sich die Freunde und Gegner Stölzls bzw. des CDU-Fraktionschefs Frank Steffel gegenseitig blockierten. \\ (http://www.tagesspiegel.de/berlin/;art270 ,2246098- Anexado em 06/06/2007)}

B1. Outro amigo de partido lembrou-se ontem de que Stölzl, um ano antes, não havia conseguido formar uma equipe líder e impô-la na eleição para a presidência. Agora provavelmente seria eleita uma nova presidência, na qual amigos e opositores de Stölzl, ou melhor, do líder da bancada do CDU, Frank Steffel, se inviabilizariam mutuamente.
B2. Ein Veto (lateinisch: "Ich verbiete") ist das Recht, gegen einen Beschluss einen Einspruch einzulegen und so zu verhindern, dass dieser wirksam wird. Im UNO-Sicherheitsrat, wo Russland bei der Abstimmung über eine neue Irak-

Resolution sein Veto angekündigt hat, haben in der Vergangenheit mehrfach eines oder mehrere der fünf ständigen Mitglieder USA, Russland, Großbritannien und China mit einem Nein Entscheidungen des höchsten UNO-Gremiums zu Fall gebracht. Insgesamt wurde seit Gründung der UNO 1946 mehr als 250-mal ein Veto eingelegt. Spitzenreiter ist Russland bzw. die ehemalige Sowjetunion, die 120-mal mit "Njet" stimmte, besonders häufig während des Kalten Krieges zwischen 1946 und 1965.

(http://www.abendblatt.de/daten/2003/03/1 1/132973.html - Anexado em 06/06/2007)
B2. Veto (em latim: "eu pró́bo") é o direito de interpor uma objeção contra uma decisão e assim impedi-la de entrar em vigor. No Conselho de Segurança da ONU, onde a Rússia anunciou seu veto durante a votação de uma nova resolução sobre o Iraque, um ou mais dos cinco membros fixos (EUA, Rússia, GrãBretanha e China) diversas vezes no passado derrubaram com um "não" decisões da comissão máxima da ONU. No total, desde a fundação da ONU em 1946, o veto foi interposto mais de 250 vezes.

A líder é a Rússia, ou melhor, a antiga União Soviética, que votou 120 vezes com um "Njet", sobretudo no período de 1946 a 1965 da Guerra Fria
B3. Wolfgang Michal demonstriert in seinem Buch_Deutschland und der nächste Krieg_(Rowohlt Berlin) zwar seine Unkenntnis in ökonomischer Zusammenhänge, hat aber das unbestreibare Verdienst, als erster Autor herausgearbeitet zu haben, wie sich von Deutschland aus der Knoten zum Dritten
B3. Embora Wolfgang Michal demonstre em seu livro "A Alemanha e a Próxima Guerra" (Rowohlt Berlin) desconhecimento de relações econômicas, não deixa de ter o mérito incontestável de ser o primeiro autor a expor como se forma, a partir da Alemanha, o nó para a III Guerra: "A História do império alemão 
Weltkrieg schürzt: "Die Geschichte des

Deutschen Reiches wiederholt sich. Es

läuft wieder genauso $a b$ wie nach der

Reichsgründung 1871. DAs

wiedervereinigte Deutschland wir das

europäische Gleichgewicht zerstören. Bei

Bismarck folgte auf die Reichseinigung

1871 eine kurze Phase stabilisierender

Europapolitik, dann eine länger des

europäischen Zerfalls, parallel eine kurze

Periode der Weltpolitik und schließlich ein

langer Anlauf zum Krieg. Bei Hitler ging

alles im Zeitraffer. Wie viele Jahre

brauchen wir?"

Michal analogisiert 1995 in etwa mit 1876:

Fünf Jahre seit der Herstellung eines

großen, einheitlichen Deutschland sind

vergangen, an der Spitze des Staates steht

mit Bismarck bzw. Kohl ein Politiker, der

mit einer komplizierten Bündnis- und

Rückversicherungsstrategie die

europäische Balance austarieren will. Die

Strategie scheitert am Balkan, wo sich die

Ambitionen der Großmächte kreuzen. Der

Lotse Bismarck geht von Bord, Wilhelm

Zwo und Tirpitz träumen vom Platz an der

Sonne, der Krieg wird unvermeidlich.

(http://www.comlink.de/cl-

hh/m.blumentritt/agr77.htm - Anexado em $12 / 06 / 2007$ )

B4. Bei der Neuauflage des Spiels wurde vorallem wert darauf gelegt, dass sich die Grafik von den Vorgängerspielen abhebt und die sogenannte "Knuddeloptik" der Siedler trotzdem vorhanden bleibt.

Herausgekommen ist eine stufenlos zoombare 3D Grafikengine, die keine

Wünsche offen lässt. Soweit man einen

Leistungsstarken Computer hat, gibt es bei voller Grafikleistung allerhand $\mathrm{zu}$

bestaunen und zu beobachten. So gibt es

eine unglaubliche Detailanzahl, die zwar

sehr lieblich gemacht sind, aber eigentlich

nichts zum Spiel selbst beitragen. Denn

wen interessiert es denn, ob da rote

Blumen auf der Wiese wachsen?! Schön

anzusehen ist es auf jeden Fall dennoch. se repete. Mais uma vez, tudo se desenrola exatamente como depois da fundação do império em 1871. A Alemanha reunificada vai destruir o equilíbrio na Europa. $\mathrm{Na}$ época de Bismarck, à unificação de 1871 seguiu-se uma fase curta de estabilização na política européia, depois uma mais longa de decadência, em paralelo um curto período de política internacional e, finalmente, uma longa investida rumo à guerra. Com Hitler tudo se acelerou. De quantos anos precisamos?"

Michal faz uma certa analogia entre 1995 e 1876: passaram-se cinco anos desde a criação de uma Alemanha grande e integrada; no topo do Estado com Bismarck, ou melhor, Kohl está um político que deseja manter o equilíbrio na Europa por meio de uma complicada estratégia de aliança e salvaguarda. A estratégia fracassa nos Bálcãs, onde as ambições das grandes potências se interpõem. O piloto Bismarck desembarca, Guilherme Segundo e Tirpitz sonham com um lugar ao sol, a guerra se torna inevitável.
B4. Na nova edição do jogo, enfatizou-se sobretudo o contraste gráfico com os jogos anteriores, mas mantendo o chamado "visual fofo". O resultado foi um gráfico em 3D contínuo que permite zoom e não deixa nada a desejar. Desde que se tenha um Computador de alto desempenho, há em toda a produção gráfica muito a ser admirado e observado. Assim sendo, existe um número inacreditável de detalhes realmente encantadores, mas que no fundo não contribuem em nada para o jogo. Afinal, a quem interessa se crescem flores vermelhas no prado?! De qualquer forma, é belo de ver. De fato, renunciou-se totalmente aos efeitos grandiosos, já que a parte gráfica não deveria ficar mais em 


\begin{tabular}{|c|c|}
\hline $\begin{array}{l}\text { Auf große Effekte wurde eigentlich ganz } \\
\text { verzichtet, da ja weiterhin nicht die Grafik } \\
\text { im Vordergrund stehen soll, sondern das } \\
\text { Spiel an sich bzw. das Spiel als Ganzes. } \\
\text { Alles in allem wurde ein sehr gutes } \\
\text { Mittelmaß gefunden, dass das Spiel nicht } \\
\text { nur durch die tolle Grafik glänzt, sondern } \\
\text { auch, dass das "Siedeln" an sich im } \\
\text { Mittelpunkt bleibt. } \\
\text { (http://www.ciao.de/Die_Siedler_2_Die_n } \\
\text { achste_Generation_PC_Test_3133434- } \\
\text { Anexado em 12/06/2007) }\end{array}$ & $\begin{array}{l}\text { primeiro plano, mas o jogo em si, ou } \\
\text { melhor, o jogo como um todo. De forma } \\
\text { geral, encontrou-se um ótimo meio-termo: } \\
\text { o jogo se distingue não apenas pelo gráfico } \\
\text { bacana - mas também por ele - e } \\
\text { "colonizar" continua sendo o ponto } \\
\text { central. }\end{array}$ \\
\hline
\end{tabular}

B5. Die Wahrheit gleicht einer göttlichen Schatztruhe voller Geheimnisse. Öffnet man sie, so kommt stets eine noch größere und einzigartigere Schatztruhe, die gefüllt ist mit immer neuen Geheimnissen, aus ihr hervor. Wenn der erhabene Hüter der Geheimnisse, der Allmächtige Gott, ein Geheimnis lüftet, so entsteht ein neues Geheimnis, das gelüftet zu werden bedarf endlose Geheimnisse hinter Geheimnissen. Es ist notwendig, dass dies so ist. Denn der Mensch langweilt sich schnell. Deshalb braucht der Mensch immer neue Aufregungen. Und jeder von uns weiß, dass jede geschlossene Schatztruhe bzw. jedes verborgene Geheimnis Neugier und Aufregung im Menschen erweckt. Und schöne Aufregungen sind die Freuden des Lebens.

(http://der-wahremensch.de/konversationen/SEE_Die_Lieb e_des_Hirten.html - Anexado em $12 / 06 / 2007$ )
B5. A verdade se assemelha a uma divina arca do tesouro cheia de segredos. Ao ser aberta, surge outra arca do tesouro maior e mais extraordinária cheia de segredos novos. Se o sublime guardião dos segredos, o Deus Todo-poderoso, revela um segredo, aparece então um novo segredo que precisa ser revelado segredos intermináveis um após o outro. É necessário que seja assim, pois o homem se entedia depressa. Por isso, o homem sempre precisa de novos estímulos. E cada um de nós sabe que toda arca fechada, ou melhor, todo segredo oculto desperta curiosidade e estimula o homem. E bons estímulos constituem as alegrias da vida.
B6. Teil auch aus der Definition des Begriffs.Die erste Eigenschaft bezieht sich auf den Lern-

prozeß, welcher nötig ist, um das Produkt zu bedienen. Bei diesem Punkt zählt vor al-

lem der Zeitaufwand. Wieviel Zeit muß man investieren, damit man sein Ziel erreichen kann (vgl. Nielsen, 1993; S. 2730)? Die Forderung nach leichter Erlernbarkeit ist immer im Verhältnis zur
B6.Parte também da definição do conceito. A primeira característica se refere ao processo de aprendizagem, o qual é necessário para utilizar o produto. Nesse aspecto, conta sobretudo o tempo gasto. Quanto tempo é preciso investir para alcançar o objetivo (cf. Nielsen, 1993: p.27-30)? A exigência de fácil aprendizagem deve ser sempre avaliada em relação à tarefa, ou melhor, ao objetivo. A fácil memorização das funções 


\begin{tabular}{|l|l|}
\hline Aufgabe bzw. dem Ziel zu beurteilen. & é outra característica dos produtos com \\
Die leichte Einprägsamkeit der Funktionen & alta utilizabilidade. \\
ist eine weitere Eigenschaft von Produkten & \\
mit hoher Usability (http://www.design- & \\
usability.de/usability_eigenschaften.html - & \\
Anexado em 12/06/2007) & \\
\hline
\end{tabular}

B7. War der Raum in "Die Stunde da wir nichts voneinander wußten" ein leerer Platz, in den sich die Vielfalt der Menschen, die ihn betreten und betreten haben, ihn überqueren und auf ihm verweilen, einschreibt, um so etwas wie ein Menschheitspanorama eines Augenblicks und damit zugleich über alle Zeiten hinaus zu werden, so verwandelt sich dieser leere Platz nun in eine Enklave oder: "Enklavenbühne" (Szene 3), die sicher nicht weniger Theaterbühne ist wie jener leere Platz. Das Theater ist für Handke der Ort für Bühnenvorgänge, die nicht bloß ästhetischen sondern anthropologischen Experimenten gleichen. Er konfrontiert die Menschen, Zuschauer wie Schauspieler, mit dem Schauspiel des Lebens selbst, und das heißt mit einer Vielfalt von Erscheinungen, bzw. Sprechversuchen. (http://www.hawickert.de/handke1.htm Anexado em 12/06/2007)
B7. Se o espaço em "a hora em que não sabíamos nada um do outro" era um lugar vazio no qual se registra a variedade de pessoas que repetidamente o adentram, atravessam e ali se demoram, para ser meio que o panorama humano de um momento e, ao mesmo tempo, atemporal, então esse lugar vazio se transforma em um enclave ou "Palco do Enclave" (cena 3) que, certamente, não é menos palco teatral que aquele lugar vazio. O teatro é, para Handke, lugar para encenações que se assemelham a experimentos não apenas estéticos, mas antropológicos. Ele confronta as pessoas, tanto espectadores como atores, com o próprio espetáculo da vida, ou seja, com uma multiplicidade de fenômenos, ou melhor, tentativas de expressão.
B8. Im April nahmen im SGB III-Bereich 70.000 Per-sonen an einer

Weiterbildungsmaßnahme teil.

An Maßnahmen der beruflichen

Weiterbildung haben im April 40.200

Personen aus dem Rechtskreis SGB II

teilgenommen.

In einer Trainingsmaßnahme bzw. einer

Maßnahme zur Eignungsfeststellung waren im April 24.900 Personen,

Im April waren im Rechtskreis SGB II 30.200 Personen in einer

Arbeitsbeschaffungsmaß-nahme (ABM)

Insgesamt befanden sich im April 06 _ 165

300 Personen in diversen Maßnahmen.

(http://www.politikforum.de/forum/archiv e/index.php/t-136911.html - Anexado em
B8. Em abril, 70.000 pessoas participaram de um evento de aperfeiçoamento na região SGB III.

Em eventos para aperfeiçoamento profissional na jurisdição SGB III participaram, em abril, 40.200 pessoas. Compareceram a um treinamento, ou melhor, evento para verificação de aptidão, em abril, 24.900 pessoas. Em abril, 30.200 pessoas da jurisdição SGB II compareceram a um evento sobre recrutamento (ABM).

No total em abril de 2006, 165.300

pessoas foram a eventos diversos. 
B9. Mundwinkeloperation. Gerade um den Mund herum wird der Alterungsprozess besonders deutlich. Möchte man Falten und Fältchen entfernen, so ist es notwendig, eine Behandlungs- bzw. Operationsmethode anzuwenden, die keine sichtbaren Narben hinterlässt, da diese am Mund nicht zu übersehen wären. Durch ein Facelift wird zwar das gesamte Gesicht gestrafft, jedoch werden die feinen Mundwinkelfalten und herabhängenden Mundwinkel - durch die ein Gesicht häufig sehr traurig wirkt - dadurch nicht beseitigt. (http://www.lexikon-derschoenheit.de/lexikon/M/mundwinkeloper ation - Anexado em 12/06/2007)

B10. Der Einzug in Schloß Plaue war der entscheidende Moment im Leben der Quitzows. So schloß unser voriges Kapitel. Dietrich, der ältere, der bedeutendere, jedenfalls der politisch planvollere der beiden Brüder, kehrte von Brandenburg beziehungsweise von Schloß Plaue nach Quitzöwel zurück, und auf dieser Rückfahrt mochten sich ihm zum ersten Male Gedanken und Wünsche, die bis dahin ein bloßes Spiel seiner Phantasie gebildet hatten, als zu verwirklichende vor die Seele stellen.

(http://gutenberg.spiegel.de/fontane/5schlo es $/ 5 \mathrm{sch} 104 . \mathrm{htm}$ - Anexado em $31 / 05 / 2007$ )

B11. Alle möglichen Zeichen stehen in seinem Dienst, Bojen oder Signallaternen, die den Weg zeigen sollen, aber so zahlreich sind, daß sie mehr verwirren als orientiert. Vielleicht der interessanteste dieser vier an Brockhaus beziehungsweise an die Brockhaussche Druckerei gerichteten Briefe ist der, der die Überschrift trägt "An meinen Setzer". (http://www.literaturport.de/index.php?id= 50\&no_cache $=1 \&$ textid $=842907645$ Anexado em 31/05/2007)
B9. Operação no canto da boca. O processo de envelhecimento se torna mais evidente justamente ao redor da boca. Caso a pessoa deseje remover rugas e ruguinhas, então é necessário empregar um método terapêutico, ou melhor, cirúrgico que não deixe cicatrizes visíveis, já que não passariam despercebidas nessa região. Através do lifting, todo o rosto é esticado, entretanto as linhas finas no canto da boca e a flacidez local - que dão ao rosto uma expressão triste - não são eliminadas dessa maneira.

B10. A mudança para o castelo Plaue foi o momento decisivo na vida dos Quitzow. Assim terminou o capítulo anterior. Dietrich, o mais velho, o mais conhecido, em todo caso, o politicamente mais hábil dos dois irmãos, retornou de

Brandenburgo, ou melhor, do Castelo Plaue, para Quitzöwel. E, nessa viagem de volta, pensamentos e desejos que até então haviam constituído uma mera brincadeira da sua fantasia, pela primeira vez se apresentaram à mente como plausíveis.
B11. Em seu serviço encontram-se todos os símbolos possíveis - balizas ou lanternas de sinalização - que devem indicar o caminho, mas são tão numerosos que mais confundem do que orientam.

Talvez a mais interessante dentre as quatro cartas endereçadas a Brockhaus, ou

melhor, à tipografia de Brockhaus, é a que traz o título "Para o meu tipógrafo". 
B12. Herr von Wlazeck war ärgerlich.

Diese grobschlächtige Art des passiven

Widerstandes empörte den alten Offizier, und er verga $\beta$, da $\beta$ er jovial und

kameradschaftlich hatte sein wollen.

»Ich möchte mich nicht wiederholen. Ich

übermittle Ihnen hiemit einfach den

strikten Beföll Ihres Dienstherren, mir zum

Zwecke des Ausreitens den Gaul sowie

alles Notwendige in Bereitschaft zu

stellen. Ich werde Ihnen Tag und Stunde

bekannt geben, beziehungsweise, Sie

werden das von kompetenter Seite

erfahren ... «

Die Zehen Hansgirgls verkrampften sich, wahrscheinlich deutete es den Eigensinn dieses verschlossenen und finsteren

Charakters an.

(http://gutenberg.spiegel.de/thoma/altaich/ altai10.htm - Anexado em 31/05/2007)

B13. Anmerkung: Wir sind hier an einem der Punkte angelangt, verehrter Freund, die vielleicht eines Kommentars bedürfen — ob nämlich die Zauberhoffnungen

Wahnmochings, beziehungsweise deren

Erfüllung wirklich im Bereich des

Möglichen lagen. Sicher wird das

Publikum die berechtigte

An[[796]]forderung erheben, darüber aufgeklärt zu werden. Uns selbst schien es anfangs sehr zweifelhaft, aber als wir zu

Ende gelesen hatten, fühlten wir uns doch geneigt, die Frage mit: Ja, oder:

Höchstwahrscheinlich — zu beantworten.

Sie werden ja auch sehen, daß die

bedeutendsten Köpfe jenes Stadtteils

einmütig daran glaubten.

(http://www.wolfgang-

rieger.de/OnlineTexte/Reventlow/Dame.ht m - Anexado em em 31/05/2007)

B14. Etwa ein Dutzend neuer

Unternehmen decken diese Dienstleistung

heute ab. Aber es gibt auch

Gefahrenpunkte bei dieser Art der

Prozessfinanzierung. Lutz Wilde,
B12. O senhor von Wlazeck estava

nervoso. Essa forma grosseira de

resistência passiva indignou o velho oficial

e ele esqueceu que havia desejado ser

jovial e camarada. "Não quero me repetir.

Estou apenas lhes comunicando a ordem

estrita do seu mestre de me colocar à

disposição para exercitar o cavalo e cuidar

do que for necessário. Vou lhes informar

dia e hora, ou melhor, virão a saber de

fonte autorizada..."

Os dedos dos pés de Hansgirgl se

contraíram, provavelmente indicando a

obstinação dessa personalidade reservada e sombria.
B13. Observação: aqui chegamos a um dos pontos, venerado amigo, que talvez careçam de comentário - se, pois, as esperanças de Wahnmoching, ou melhor, sua realização, se situavam realmente no âmbito do possível. Com certeza, o público fará a exigência legítima de ser esclarecido. Para nós próprios pareceu muito duvidoso no início, mas ao ler até o final nos sentimos inclinados a responder a pergunta com "sim" ou "muito provavelmente". Vocês também verão que as cabeças mais importantes da região acreditavam unanimemente nisso.
B14. Hoje cerca de uma dúzia de novas empresas prestam esse serviço. Mas há também riscos nesse modo de financiar o processo. Lutz Wilde, editor jurídico da revista Finanztest diz: "O problema com 


\begin{tabular}{|c|c|}
\hline $\begin{array}{l}\text { Rechtsredakteur der Zeitschrift Finanztest } \\
\text { meint: "Das Problem bei den } \\
\text { Prozessfinanzierern ist häufig, dass man } \\
\text { die Unternehmen einfach noch nicht kennt. } \\
\text { Es gibt keine Berufs- beziehungsweise } \\
\text { Branchenaufsicht und der heikle Punkt, ob } \\
\text { die Unternehmen selbst über eine } \\
\text { ausreichende Finanzdecke verfügen, wird } \\
\text { von niemandem überprüft. } \\
\text { (http://www.tagesspiegel.de/wirtschaft/arc } \\
\text { hiv/17.05.2002/ak-wi-re-4420769.html - } \\
\text { Anexado em 01/06/2007) }\end{array}$ & $\begin{array}{l}\text { as empresas financiadoras de processos } \\
\text { costuma ser o fato de que simplesmente } \\
\text { ainda não são conhecidas. Não há } \\
\text { nenhuma fiscalização da profissão, ou } \\
\text { melhor, do setor, e o ponto delicado - se } \\
\text { as empresas dispõem de cobertura } \\
\text { financeira suficiente - não é verificado por } \\
\text { ninguém." }\end{array}$ \\
\hline
\end{tabular}

B15. Der Fall des Frankfurter Bauriesen zeigt mustergültig, warum ein Eingreifen der Regierung, beziehungsweise überhaupt jede Art von Industriepolitik, wenig Sinn macht. Als Schröder sich damals einschaltete, warf er den Gläubigerbanken vor, "mehr an ihr Geschäft zu denken statt daran, das Unternehmen und die Arbeitsplätze abzusichern".

(http://www.tagesspiegel.de/wirtschaft/arc hiv/24.03.2002/ak-wi-558507.html Anexado em 01/06/2007)
B15. A queda do gigante da construção de Frankfurt mostra de forma exemplar por que uma intervenção do governo, ou melhor, qualquer tipo de política industrial, não faz muito sentido. $\mathrm{Na}$ época em que interveio, Schröder repreendeu os bancos credores "por pensarem mais no próprio negócio em vez de tentarem preservar a empresa e os postos de trabalho."
B16. Stellvertretend für Branchenkollegen verlieh heute der

Telekommunikationsanbieter 01051

Telecom seiner Enttäuschung Ausdruck:

"Dieses Abstimmungsverhalten ist mehr als unverständlich - es offenbart auch die Ignoranz der Politik gegenüber den Wünschen und Bedürfnissen der Bürger beziehungsweise Wähler.

(http://www.zdnet.de/news/print_this.htm? pid=2119061-39001023c - Anexado em 05/06/2007)

B17. Man wird die Weisheit des Engels in letzten Dingen loben müssen, zugleich aber darauf hinweisen dürfen, daß Leichenschmäuse nicht selten den exzessivsten Ausdruck menschlicher Lebensfreude bzw. Überlebensfreude darstellen, auch und gerade in Bayern. (http://www.zeit.de/1999/11/ 199911.finis.xml - Anexado em 12/06/2007)
B16. Representando os colegas do setor, a prestadora de serviços de telecomunicações 01051 Telecom manifestou hoje a sua frustração: "Essa votação é mais do que incompreensível mostra também a ignorância dos políticos frente aos desejos e necessidades dos cidadãos, ou melhor, dos eleitores.
B17. A sabedoria do anjo deverá ser louvada nas últimas coisas, mas ao mesmo tempo será permitido chamar a atenção para o fato de que banquetes em funerais não raro constituem a expressão mais excessiva da alegria de viver humana ou melhor alegria de sobreviver, também e justamente na Baviera. 


\begin{tabular}{|c|c|}
\hline $\begin{array}{l}\text { B18. DEUTSCHE UND ENGLISCHE } \\
\text { INTERNETTAGEBÜCHER ZUM } \\
\text { KRIEG } \\
\text { Umfassende Berichterstattung abseits der } \\
\text { üblichen Medien ist das Ziel von } \\
\text { Warblogs.cc. Hier haben sich sieben } \\
\text { Weblogs versammelt, darunter die } \\
\text { Nachrichten-Blogs ,Warblogging“ und } \\
\text { „Back to Iraq“, ein Weblog des } \\
\text { Journalisten Christopher Allbritton. } \\
\text { Bestimmendes Thema sind derzeit die } \\
\text { Genfer Konventionen, bzw. deren } \\
\text { Verletzung durch irakische und } \\
\text { amerikanische Militärs. Ein weiterer } \\
\text { Warblog, „Daily Kos“, erinnert an einen } \\
\text { erst 22-jährigen gefallenen US-Soldaten. } \\
\text { (http://www.tagesspiegel.de/subdir/art250, } \\
\text { 2281528 - Anexado em 06/06/2007) }\end{array}$ & $\begin{array}{l}\text { B18. } \\
\text { NA INTERNET, DIÁRIOS ALEMÃES E } \\
\text { INGLESES SOBRE A GUERRA } \\
\text { Cobertura ampla paralela à da mídia } \\
\text { comum é o objetivo de Warblogs.cc. Aqui } \\
\text { estão reunidos sete Weblogs, entre eles os } \\
\text { blogs de notícia "Warblogging" e "De } \\
\text { volta ao Iraque", Weblog do Jornalista } \\
\text { Christopher Allbritton. Atualmente, o } \\
\text { tema dominante são as Convenções de } \\
\text { Genebra, ou seja, sua violação por } \\
\text { militares iraquianos e americanos. Um } \\
\text { outro Warblog, "Daily Kos", lembra um } \\
\text { soldado americano morto de apenas } 22 \\
\text { anos. }\end{array}$ \\
\hline
\end{tabular}

B19. Wer keinen Wert auf einen brandneuen Wagen legt, kann bei vielen Händlern auch günstige Tageszulassungen erstehen. Bei der Nissan-Niederlassung in Berlin-Treptow gibt es dabei Rabatte bis zu 30 Prozent. Das Fiat-Autohaus Heuer, das Ford-Autohaus Airport und das AMCMazda-Center bieten Nachlässe bis zu 20 Prozent. Beim VW-Autohaus Eduard Winter stehen ab Anfang April 100 tageszugelassene Polos, die die Kunden bis zu 15 Prozent beziehungsweise bis zu 1700 Euro billiger bekommen.

(http://www.tagesspiegel.de/wirtschaft/arc hiv/22.03.2003/491036.asp - Anexado em 03/06/2007)
B19. Quem não liga para carro zero pode obter junto a muitos negociantes licenças vantajosas válidas por um dia. Na filial da Nissan em Berlim-Treptow há descontos de até $30 \%$. As concessionárias Fiat Heuer, Ford Airport e AMC-MazdaCenter oferecem abatimento de até $20 \%$. Na concessionária Eduard Winter da VW encontram-se desde o início de abril 100 Polos para licenciamento diário que saem até $15 \%$ mais barato para os clientes, ou seja, 1700 euros a menos.
B20. Diese acht Begegnungen werden im Europapokal-Modus, also mit Hin- und Rückspiel, am 15./16. November und 18./19. November 2003 ausgetragen. Die acht Sieger dieser Entscheidungsspiele qualifizieren sich für das EM-Viertelfinale beziehungsweise die EM-Endrunde. Die vier Teams, die das Halbfinale des Europameisterschafts-Wettbewerbs bestreiten, nehmen auch an den Olympischen Sommerspielen 2004 in
B20. Essas oito competições serão realizadas nos moldes da Taça Européia, portanto com jogos de ida e volta, nos dias 15 e 16 e 18 e 19 de novembro de 2003. Os oito ganhadores dessas partidas decisivas se qualificam para as quartas-definal do campeonato europeu, ou seja, para a rodada final. Os quatro times que disputam a semifinal do campeonato europeu participam também dos Jogos Olímpicos de Verão de 2004 em Atenas. 
Athen teil. (http://www.fp-

sport.de/de/news/details/frmArticleID/236

8/ - Anexado em 03/06/2007)

B21. Gemeinsame Presseerklärung der

Kultusminister der unionsregierten

Länder

Die Kultusminister von Baden-

Württemberg, Bayern, Hamburg, Hessen,

Saarland, Sachsen und Sachsen-Anhalt und Thüringen stellen zu den Äußerungen von

Bundesbildungsministerin Edelgard

Bulmahn klar: Unter den Kultusministern

der unionsregierten Länder herrscht

keinerlei Dissens über die Verwendung der

vier Milliarden Euro des Bundes zum

Ausbau von Ganztagesangeboten bzw.

Ganztagesschulen.

(http://www.km.bayern.de/km/asps/presse/

presse_anzeigen.asp?index $=289$ - Anexado

em 12/06/2007)
B21. Declaração coletiva dada à imprensa pelos ministros estaduais da Educação

Os ministros da Educação de BadenWürttemberg, Baviera, Hamburgo, Hessen, Sarre, Saxônia, Saxônia-Anhalt e Turíngia contestam as declarações da ministra federal da Educação Edelgard Bulmahn: entre os ministros estaduais da Educação não reina nenhuma discordância sobre a aplicação dos quatro bilhões de euros da federação para ampliação das ofertas de período integral, ou seja, de escolas de período integral.
B22. Mit 36 Jahren und der Ausbildung als

Polizeikommissar habe ich jedoch im Moment keine Chancen auf dem freien Arbeitsmarkt und so werde ich nun wohl doch dem Staat, bzw. dem Land Berlin finanziell zur Last fallen müssen. (http://www.kandidatenwatch.de/weitere_fr agen_an_klaus_wowereit-323-8433-1p405.html - Anexado em 06/06/2007)
B22. Com 36 anos e formação como delegado de polícia, no entanto, não tenho no momento nenhuma chance no mercado de trabalho livre e, assim, é provável que eu tenha de me tornar um fardo para os cofres do país, mais precisamente, da cidade-estado Berlim.
B23. Auf dem Arbeitsmarkt gibt es Milliarden für Weiterbildung, Umschulung und ABM. Sonderbar ist, dass die größten Kunden der Weiterbildungsetats diejenigen sind, die die Arbeitsämter kontrollieren sollen: Gewerkschaften und Arbeitgeberverbände, beziehungsweise deren Weiterbildungswerke. (http://www.tagesspiegel.de/wirtschaft/arch iv/09.03.2002/ak-wi-5512011.html Anexado em 03/06/2007)
B23. No mercado de trabalho há bilhões para aperfeiçoamento profissional, readaptação e medidas de obtenção de trabalho. É curioso o fato de que os maiores clientes do orçamento para aperfeiçoamento profissional são aqueles que os departamentos de trabalho devem controlar: sindicatos e sindicatos patronais,

mais precisamente seus centros de aperfeiçoamento profissional. 
B24. Die britische Regierung hat indes eingeräumt, dass sie keinen "absoluten Beweis" für die "Hinrichtung" zweier britischer Soldaten im Südirak hat. Premierminister Tony Blair und USPräsident George W. Bush hatten am Donnerstag bei ihrer Pressekonferenz in Camp David davon gesprochen, dass die Soldaten "hingerichtet" beziehungsweise "ermordet" worden seien. "Das ist ein Kriegsverbrechen", hatte Bush gesagt. (http://www.enfal.de/ak68.htm - Anexado em 03/06/2007)
B24. No entanto, o governo britânico admitiu que não tem "nenhuma prova absoluta" da "execução" de dois soldados britânicos no Sul do Iraque. O primeiroministro Tony Blair e o presidente norteamericano George W. Bush haviam dito, na coletiva de imprensa realizada quinta-feira em Camp David, que os soldados haviam sido "executados", mais precisamente "assassinados". "Isso é crime de guerra", disse Bush.
B25. Natterer verstand die Situation und redete möglichst laut, um den Gelehrten wach zu erhalten.

»Entschuldingen schon, Herr Professa, daß ich quasi unangemeldet bei Ihnen

vorspreche, aba ich möchte mit Ihnen betreff einer Kunstsache konferieren, weil Sie betreff einer solchen Frage quasi eine Autorität sind ... «

In Hobbes Augen blitzte kein Verständnis auf, aber der Kaufmann fuhr herzhaft und unbekümmert weiter:

»Indem es sich nämlich um die

Anfertigung oder beziehungsweise um die Herstellung von einem künstlerischen Panorama unseres Kurortes handelt, weil man diese betreffenden Panorama jetzt öfter sieht, zum Beispiel in diverse Bahnhöf. » (http://gutenberg.spiegel.de/thoma/altaich/a ltai04.htm - Anexado em 31/05/2007)
B25. Natterer compreendeu a situação e falou o mais alto possível, para manter o erudito desperto.

"Desculpe-me, senhor professor, por vir à sua casa praticamente sem avisar, mas eu gostaria de discutir com o senhor um assunto ligado à arte, pois com relação a uma certa questão o senhor é praticamente uma autoridade..."

Nos olhos de Hobbes não houve nenhum lampejo de compreensão, mas o comerciante prosseguiu resoluto e calmo: "Afinal, trata-se é da execução ou, melhor ainda, da concepção do panorama artístico da nossa estação termal, pois o panorama em questão agora é visto com freqüência, por exemplo em diversas estações ferroviárias."

\subsubsection{Tipo C - Alternatividade}

O tipo de uso C, que apresenta uma alternatividade entre opções ligadas por bzw., é o mais freqüente no corpus da pesquisa, com $59 \%$ do total das ocorrências. Isso permite comprovar que uso principal da conjunção beziehungsweise é realmente, como apontam as gramáticas, expressar a alternatividade. 
A análise das ocorrências do corpus levou à constatação de que este tipo de uso na realidade engloba dois grandes subtipos, definidos a partir da compatibilidade das alternativas apresentadas: a) um grupo traz alternativas apresentadas como excludentes ou independentes entre si; b) o outro apresenta alternativas que podem co-ocorrer em certa medida.

As 61 ocorrências do tipo $C$ encontradas no corpus distribuem-se da seguinte maneira em relação aos seus dois subtipos:

\begin{tabular}{|c|c|c|}
\hline Subtipo & Ocorrências & Porcentagem \\
\hline Ca (excludente) & 22 & $36 \%$ \\
\hline $\mathrm{Cb}$ (não-excludente) & 39 & $64 \%$ \\
\hline
\end{tabular}

Nota-se que o subtipo $\mathrm{Cb}$ é mais freqüente, embora isso possa se dar pelo fato de que este subtipo engloba várias possibilidades de combinações de elementos, enquanto o subtipo $\mathrm{Ca}$ apresenta apenas a combinação de dois elementos, conforme detalhado a seguir.

\section{Subtipo Ca: Alternativas excludentes}

Beziehungsweise pode ser utilizado para introduzir duas alternativas ou possibilidades que se alternam, se excluem mutuamente, ou que são apresentadas como completamente independentes.

Como exemplos de alternativas excludentes, podemos destacar "isenção / subsídios" (Ca2), pois os estudantes que são isentos não têm subsídios e vice-versa; "processar / editar" (Ca7), já que a imagem não pode ser editada e processada ao mesmo tempo; "microscópio / telescópio" (Ca16), já que não se pode olhar ao mesmo tempo nos dois aparelhos, nem obter os mesmos resultados dos exames.

Alguns exemplos de alternativas não necessariamente excludentes, mas que são vistas como possibilidades que ocorrem de modo independente, são: "setor comercializado / privatizado" (Ca9), onde qualquer um dos dois setores pode iniciar o processo, mas ambos podem fazê-lo; "ver / observar" (Ca17) ou 
"espreitar / escutar" (Ca25), onde se pode realizar as duas ações ao mesmo tempo, mas que são apresentadas aqui como processos distintos.

Em português, o tipo $\mathrm{Ca}$, ou alternatividade excludente, foi expresso através da conjunção "ou" em todas as 22 ocorrências do corpus.

\begin{tabular}{|c|c|}
\hline $\begin{array}{l}\text { mehr als } \\
\text { he } \\
\text { ttliche } \\
\text { nd bei } \\
\text { len mit } 80,6 \\
\text { it beträgt } \\
900 \\
\text { drchschnitt } \\
\text { d }\end{array}$ & $\begin{array}{l}\text { Ca1. "Trabalho é metade da vida" } \\
\text { (sabedoria popular) } \\
\text { Errado: trabalho é mais do que metade da } \\
\text { vida. Segundo o Departamento Federal de } \\
\text { Estatística, a expectativa média de vida na } \\
\text { Alemanha é de } 74,4 \text { anos para os homens e } \\
80,6 \text { anos para as mulheres. O período } \\
\text { trabalhado ao longo da vida totaliza } 40,6 \\
\text { anos (situação em 1990). Por volta de } \\
1900 \text {, os alemães trabalhavam em média } \\
43,8 \text { anos. Infância, anos de educação } \\
\text { escolar, profissionalização ou faculdade } \\
\text { consomem hoje cerca de } 19,4 \text { anos (1900: } \\
14,2 \text { anos). A duração do período de } \\
\text { aposentadoria estendeu-se de maneira } \\
\text { drástica: de } 4,8 \text { anos por volta de } 1900 \text { para } \\
16,4 \text { anos atualmente. }\end{array}$ \\
\hline
\end{tabular}

Ca2. Seit dem Wintersemester 2002/03 erhalten Studierende der FU für 112 Euro ein Semesterticket. Der Studentenausweis gilt dann in Verbindung mit einem amtlichen Lichtbildausweis als Fahrausweis. Unter bestimmten Voraussetzungen ist für manche Studenten eine Befreiung bzw. finanzielle Unterstützung vorgesehen. Zuständig ist das Semesterticket-Büro des Studentenwerks, Habelschwerdter Allee 45, Räume KL 29/102 + 103, 14195 Berlin, Tel.: 838-54441, E-Mail: semtix @ zedat.fuberlin.de.

(http://web.fu-berlin.de/fun/2003/3-42003/studierende/studierende1.html Anexado em 06/06/2007)
Ca2. Desde o inverno de 2002/03, os estudantes da FU recebem um comprovante semestral pelo valor de 112 euros. Assim, a carteira de estudante juntamente com um documento de identificação com fotografia vale como carteira de motorista. Sob determinadas condições, prevê-se isenção ou subsídio para alguns estudantes. A emissão é de responsabilidade do escritório de comprovantes semestrais da União dos Estudantes, Habelschwerdter Allee 45, salas KL 29/102 + 103, 14195 Berlim, Tel.: 838-54441, E-Mail: semtix @ zedat.fuberlin.de. 
Ca3. >>Kriminalpräventiver Rat<<

Wer sind wir:

Wir verstehen uns als Beratungsgremium des Oberbürgermeisters und empfehlen Maßnahmen, die dazu beitragen können, die Kriminalität in der Landeshauptstadt Dresden vorbeugend zu verhindern bzw. zu verringern. Dem Kriminalpräventiven Rat gehören ständige und wechselnde Mitglieder an. Zu den ständigen gehören die Vertreter und Vertreterinnen der Stadtverwaltung, die vom Stadtrat gewählten Mitglieder und die der Polizeidirektion Dresden. Zu den wechselnden Vertretungen gehören die Vertreter und Vertreterinnen der Fachbehörden, externe Berater/-innen, Sachverständige, Verbände und Vereine, Kirchen, Gewerkschaften, sonstige Instiutionen und die Staatsanwaltschaft.Unser Angebot:

- Arbeitsgruppe Demokratie und Toleranz

- Arbeitsgruppe gegen Vandalismus

- Arbeitsgruppe Sportstättensicherheit

- Arbeitsgruppe Gewaltprävention

- Arbeitsgruppe Kriminalprävention und Stadterneuerung.

Unsere Arbeitsgruppen sind nicht öffentlich.

(http://www.dresden.de/de/03/045/c_06.ph p - Anexado em 12/06/2007)
Ca3. "Conselho para Prevenção da

Criminalidade"

Quem somos:

A nosso entender somos um órgão consultivo do prefeito-mor e aconselhamos medidas profiláticas que podem contribuir para impedir ou reduzir a criminalidade em Dresden, a capital do Estado.

Fazem parte do Conselho para Prevenção da Criminalidade membros permanentes e temporários. Constituem membros permanentes os representantes da prefeitura, os membros eleitos pela Câmara municipal e os representantes da administração da polícia de Dresden. Constituem membros temporários os representantes de repartições especializadas, consultores(as), peritos, associações e sociedades, igrejas, sindicatos, outras instituições e o ministério público. Nossa proposta:

- Grupo de trabalho Democracia e Tolerância

- Grupo de trabalho contra o Vandalismo

- Grupo de trabalho Segurança em Estádios

- Grupo de trabalho Prevenção da Violência

- Grupo de trabalho Prevenção da Criminalidade e Reforma Urbana

Nosso grupos de trabalho não são públicos.
Ca4. Ferienwohnung Fleesensee

Seit März 2003 können Sie folgende neu gebaute Ferienwohnung für vier Personen mieten: Die Ferienwohnung befindet sich in dem mit dem Kreis markierten Haus. Sie können über uns auch die Wohnungen in den benachbarten Häusern anfragen, insbesondere wenn sie eine

Raucherwohnung wünschen, bzw. eine, in die Sie Ihr Haustier mitbringen wollen. Die Ausstattungen variieren natürlich.

(http://www.fleesensee-fewo.de/ - Anexado em 12/06/2007)
Ca4. Acomodação de Férias Fleesensee Desde março de 2003, você pode alugar o seguinte apartamento de temporada para quatro pessoas recentemente construído: $\mathrm{O}$ apartamento se encontra na casa marcada com o círculo. Você pode nos solicitar também acomodação nas casas vizinhas, especialmente se desejar uma acomodação para fumantes ou uma aonde possa levar seu animal de estimação. As instalações variam, claro. 


\begin{tabular}{|c|c|}
\hline $\begin{array}{l}\text { Ca5. Nach einer kurzen ersten Periode zu } \\
\text { Beginn der 90er Jahre, in der sich Euphorie } \\
\text { und Larmoyanz mischten, wurde begonnen, } \\
\text { Fehler auf Fehler zu setzen, ja das } \\
\text { zivilisatorische Rad selbst wieder } \\
\text { zurückzudrehen: Die Nato, im } \\
\text { Selbstverständnis die "mächtigste } \\
\text { Militärallianz aller Zeiten", fing an, } \\
\text { gesteuert von ihrer Vormacht USA, nach } \\
\text { und nach ihre zivile Konkurrenz, die } \\
\text { OSZE, "wegzubeißen" und (mit etwas } \\
\text { Verzögerung) auch die Vereinten Nationen } \\
\text { zurückzudrängen. } \\
\text { Kriegsverhütung als Doktrin wurde } \\
\text { aufgegeben, und die Verteidigungskräfte } \\
\text { wurden bzw. werden zu Einsatzarmeen } \\
\text { umgebaut. } \\
\text { (http://www.uni- } \\
\text { kassel.de/fb5/frieden/science/lutz.html - } \\
\text { Anexado em 12/06/2007) }\end{array}$ & $\begin{array}{l}\text { Ca5. Depois de um curto primeiro período } \\
\text { no início dos anos } 90 \text { em que euforia e } \\
\text { sentimentalismo se misturaram, a própria } \\
\text { roda civilizatória, num erro após o outro, } \\
\text { começou a girar para trás: A OTAN, em } \\
\text { sua própria concepção a "mais poderosa } \\
\text { aliança militar de todos os tempos", guiada } \\
\text { pelos EUA, sua principal potência, } \\
\text { começou pouco a pouco a "repelir" sua } \\
\text { oposição civil, a OSCE, e (com alguma } \\
\text { demora) a afastar também as Nações } \\
\text { Unidas. Renunciou-se à prevenção da } \\
\text { guerra como doutrina e as forças de defesa } \\
\text { foram ou serão reorganizadas como } \\
\text { exército de ocupação. }\end{array}$ \\
\hline
\end{tabular}

Ca6. Central Point (CP) ist berechtigt, von einem angenommenen Auftrag zurückzutreten, wenn sich ergibt, dass aus rechtlichen, technischen oder betrieblichen Gründen, insbesondere bei einem Verstoß gegen die Vorschriften der "Allgemeinen Anweisung über Werbung, Handel, Sammlungen und politische Betätigung in und mit Einrichtungen des Landes Berlin" (AllA Werbung), die Werbung nicht durchführbar ist, der Auftraggeber unrichtige Angaben gemacht hat, gegen gesetzliche Bestimmungen bzw. gegen die guten Sitten verstößt oder die Werbung von den Vertragspartnern von CP oder berechtigter Weise von sonstigen Dritten beanstandet wird. (http://www.central-point.com/agb.php Anexado em 12/06/2007)

Ca7. Hier hat man ein Dateiformat das beim speichern keinen Verlust der Qualität produziert. Auch wenn Bilder digital bearbeitet werden, gibt es beim TIFF keinen Qualitätverlust. Einziger Nachteil gegenüber dem JPEG - durch die höhere
Ca6. A Central Point (CP) está autorizada a abdicar de uma encomenda aceita caso resulte que por razões legais, técnicas ou operacionais, especialmente em caso de infração dos preceitos da "Instrução geral sobre propaganda, comércio, arrecadação e atividade política em e com instituições do Estado de Berlim" (AIIA Propaganda), a propaganda é inviável, o cliente ofereceu informações incorretas, atenta contra determinações legais ou contra os bons costumes, a propaganda sofreu objeção das partes contratantes ou, de forma legítima, de terceiros.
Ca7. Tem-se aqui um formato de arquivo que ao armazenar não leva à perda da qualidade. Ao aprimorar imagens digitais com TIFF também não há perda de qualidade. Única desvantagem em relação ao JPEG - por ser um arquivo grande não é 


\begin{tabular}{|c|c|}
\hline $\begin{array}{l}\text { Dateigröße kann man nicht so viele Fotos } \\
\text { speichern. } \\
\text { TIFF wenn kein RAW-Format möglich ist } \\
\text { und eine hohe Bildqualität erwünscht wird. } \\
\text { TIFF wenn in die Bilddateien weiter } \\
\text { verarbeitet bzw. bearbeitet werden sollen } \\
\text { (höhere Qualität als JPEG). } \\
\text { (http://www.photohomepage.de/fototipps_- } \\
\text { ditigrale_fotografie_welches_dateiformat_i } \\
\text { st_das_beste.htm - Anexado em } \\
\text { 12/06/2007) }\end{array}$ & $\begin{array}{l}\text { possível armazenar muitas fotos. } \\
\text { TIFF quando nenhum formato RAW é } \\
\text { possível e se deseja imagens de alta } \\
\text { qualidade. } \\
\text { TIFF quando se deve continuar } \\
\text { processando ou editando os arquivos de } \\
\text { imagens (alta qualidade como JPEG). }\end{array}$ \\
\hline
\end{tabular}

Ca8. Wenn Sie sich nicht sicher sind, ob diese für Ihr Praktikum geeignet ist (siehe Frage 3: Welche Praktikumsstellen sind für mich geeignet?), kommen Sie am Besten vor der Kontaktaufnahme mit der Praktikumsstelle zur Beratung ins Praktikumsbüro (Praktikum im Grundstudium) oder zu einer Vertreterin/einem Vertreter Ihres Studienschwerpunkts (Praktikum im Hauptstudium).Ansonsten besorgen Sie sich aus dem Sekretariat des Praktikumbüros oder auf der Web-Seite des Praktikumsbüros das Formblatt „Praktikumsbescheinigung“ für das Grundstudium bzw. für Hauptstudium. (http://www.uni-due.de/ibw/praktikumalles_ueber.shtml - Anexado em $12 / 06 / 2007$ )

Ca9. Verbesserungen vor allem im schulischen sowie im außerschulischen Bildungsbereich sind notwendig. Offensichtlich übt der Wandel der Sozialisationsbedingungen außerhalb von Schule großen Druck aus auf ihre Rolle und Funktion im Prozeß der Sozialisation; in dieser Situation der Verunsicherung müssen Bildungs- und

Erziehungsinstitutionen ihre historische Rolle als Sozialisationsfelder im gesellschaftlichen und moralischen Kontext inhaltlich und formal neu begreifen und einen neuen Orientierungsraum bieten. Gerade Inhalte der Jugendkulturarbeit und einer erweiterten Jugendsozialarbeit, im
Ca8. Se não tem certeza de que o estágio é adequado para você (veja pergunta 3:

Quais vagas de estágio são para mim?), antes de contatar o lugar que oferece a vaga é melhor se aconselhar na Central de Estágios (estágio no nível básico) ou procurar um representante da sua área de concentração (estágio no nível avançado). Caso contrário, obtenha junto à secretaria da Central de Estágios ou no website da Central o formulário "certificado de estágio" para o nível básico ou avançado.
Ca9. Melhoras são necessárias sobretudo no âmbito da formação dentro e fora da escola. Evidentemente, a mudança nas condições de socialização fora da escola exerce grande pressão sobre o papel e a função escolares no processo de socialização; nessa situação de incerteza, instituições de formação e ensino devem reinterpretar no contexto social e moral a forma e o conteúdo do seu papel histórico como campo de socialização e oferecer uma nova orientação. $\mathrm{O}$ volume direto do trabalho cultural e do expandido trabalho social dos jovens deveria começar a ser intensificado no setor comercializado ou privatizado; apenas através da cooperação 
kommerzialisierten bzw. privatisierten

Sektor, sollten verstärkt in Angriff genommen werden; nur durch die

Kooperation wird es künftig möglich sein, diesen einseitigen Entwicklungen und der

Gefahr der Auseinanderentwicklung, der

Trennung von Körper und Seele, entgegenzusteuern.

(http://www.diplom.de/db_mwexchange/di plomarbeiten8331.html - Anexado em $12 / 06 / 2007$ ) será possível, no futuro, fazer frente a esses desenvolvimentos desequilibrados, ao perigo de desagregação e à separação entre corpo e mente.
Ca10. Als Günter Grass damals vor genau vierzig Jahren in seiner berühmten Blechtrommel den zwergwüchsigen, glaszersingenden Oskar Mazerath zum deutschen Helden machte, ahnte er nicht, was er sich und der Literaturgeschichte damit antat, denn alle Romane, die er danach schrieb, und alle Figuren, die er danach erfand, wurden an der

Blechtrommel und an Oskar Mazerath gemessen. Seitdem nennt man in der Wissenschaft den für einen Dichter unglückseligen Vorgang literarischer, generell kultureller Geringschätzung und also Wertminderung im Angesicht übergroßen ersten Ruhms "Mazerathion" bzw. nach neuerer Schreibweise "Mazeration". (http://www.zeit.de/1999/13/199913.finis.x ml - Anexado em 12/06/2007)

Ca11. Unsere Angebote sind bezüglich Preis, Menge, Lieferfristen und Liefermöglichkeiten stets freibleibend. Der Vertrag kommt erst durch unsere Auftragsbestätigung zustande. Für alle Lieferungen, Leistungen, Angebote gelten diese AGB sofern mit dem Besteller bzw. Kunden nicht etwas anderes schriftlich vereinbart wurde. Diese Geschäftsbedingungen, in der jeweils gültigen Form, gelten auch dann, wenn in der späteren Geschäftsbeziehung keine ausdrückliche Bezugnahme auf sie
Ca10. Quando há exatos 40 anos, Günter Grass transformou em herói alemão Oskar Mazerath, o nanico que estilhaçava vidros ao cantar no famoso "O Tambor", ele não suspeitava do que estava fazendo para si e para a história da literatura, pois todos os romances que escreveu depois e todos os personagens que inventou posteriormente foram avaliados a partir de "O Tambor" e Oskar Mazerath. Desde então, o triste incidente de desprezo literário e cultural de forma geral, ou seja, de decadência de um escritor em face de um primeiro sucesso grandioso é chamado de "Mazerathion" ou, segundo a nova grafia, "Mazeration"
Ca11. Com relação a preço, quantidade, prazo de entrega e possibilidades de entrega, nossas ofertas estão sempre sujeitas a alteração. $\mathrm{O}$ acordo é validado somente depois da confirmação da encomenda. Para todas as entregas, pagamentos e ofertas valem estas determinações gerais desde que não se tenha firmado outro tipo de acordo por escrito com o solicitante ou cliente. Tais determinações em sua forma corrente valem mesmo se na última transação comercial não foi feita expressa referência a elas. 
erfolgen sollte.

(http://www.thueringer-

porzellan.com/agb.php?PHPSESSID

$=8 \mathrm{ad} 0 \mathrm{c} 52 \mathrm{bc} 1106 \mathrm{cfa}$ fffa67e044a2e3c

f - Anexado em 12/06/2007)

Ca12. Als ein wesentliches Ergebnis des

Workshops kann die Kooperation der

wissenschaftlichen Beiräte und Attac-

Gruppen auf europäischer Ebene

angesehen werden. Es wurde eine Kontakt-

bzw. Kooperationsgruppe gegründet,

welche die Aufgabe verfolgt, die

Arbeitsweise, Produkte (z.B.

Publikationen) und Diskussionen des

jeweiligen Landes kennenzulernen, um

bspw. Übersetzungen von

Veröffentlichungen vorzunehmen,

gemeinsame Publikationen zu erstellen

sowie sich gegenseitig ReferentInnen zu

vermitteln.

(http://sandimgetriebe.attac.at/index.php?id

$=1760 \&$ type $=98$ - Anexado em

$12 / 06 / 2007)$
Ca12. A cooperação entre os conselhos científicos e os grupos Attac no plano europeu pode ser vista como consequiência fundamental do workshop. Foi criado um grupo de contato ou de cooperação, o qual está incumbido da tarefa de conhecer a forma de trabalho, os produtos (por exemplo, publicações) e as discussões dos respectivos países para, a título de exemplo, propor traduções de obras, lançar publicações coletivas, assim como intermediar palestrantes em comum.
Ca13. Eine Voraussetzung für den Erhalt dieses 'Dokuments' ist das Vorhandensein einer Bescheinigung des behandelnden Arztes bzw. Psychologen über "vermutetes transsexuelles Syndrom" oder "Erprobung der Lebbarkeit der angestrebten Geschlechtsrolle". Es genügt auch die Kopie einer Überweisung, aus der die Angaben hervor gehen oder eines Rezeptes, wenn die Hormonbehandlung bereits begonnen hat.

(http://www.dgti.org/ergaus.htm - Anexado em 12/06/2007)
Ca13. Uma condição para o recebimento desse "documento" é a existência de um atestado médico ou psicológico sobre "suposta síndrome transexual" ou "verificação de viabilidade do papel sexual almejado". Basta também a cópia de um encaminhamento do qual resultem as informações ou de uma receita, caso o tratamento hormonal já tenha sido iniciado.

Ca14. Etwas anders gestaltet sich die Suche mit allgemeinen Themenkatalogen wie beispielsweise Yahoo oder web.de. Diese Kataloge bieten Oberkategorien wie Gesellschaft, Wirtschaft, Sport und Unterhaltung und auch rein netzbasierte Themen wie Online-Einkaufen oder Internet. Die Beschreibungstexte zu den

Ca14. É um pouco diferente a procura com catálogos temáticos genéricos como, por exemplo, Yahoo ou web.de. Esses catálogos oferecem categorias abrangentes como sociedade, economia, esporte e entretenimento, assim como temas baseados puramente na rede, como compras on-line ou Internet. Os textos 


\begin{tabular}{|l|l|}
\hline $\begin{array}{l}\text { jeweils verwiesenen Homepages sind kurz } \\
\text { und folglich oft aussagelos, bzw. die Texte } \\
\text { existieren gar nicht erst. } \\
\text { (http://www.zeit.de/2000/07/200007.katalo } \\
\text { ge.xml - Anexado em 12/06/2007) }\end{array}$ & $\begin{array}{l}\text { descritivos das homepages indicadas são } \\
\text { curtos e, por conseguinte, muitas vezes sem } \\
\text { sentido, ou os textos simplesmente não } \\
\text { existem. }\end{array}$ \\
\hline
\end{tabular}

\begin{tabular}{|c|c|}
\hline $\begin{array}{l}\text { Ca15. Was ist besonders wichtig für private } \\
\text { Aktionäre? } \\
\text { Für den kleinen Geldanleger ist die } \\
\text { Neuregelung für Termingeschäfte wichtig. } \\
\text { Bislang konnte er solche Geschäfte bei } \\
\text { Verlusten wieder rückgängig machen; } \\
\text { vorausgesetzt, er hatte zuvor keine } \\
\text { entsprechende Risikoerklärung seiner Bank } \\
\text { unterschrieben beziehungsweise die } \\
\text { Geltungsdauer der Erklärung war } \\
\text { überschritten. } \\
\text { (http://www.tagesspiegel.de/wirtschaft/arch } \\
\text { iv/20.03.2002/ak-wi-4412458.html - } \\
\text { Anexado em 03/06/2007) }\end{array}$ & $\begin{array}{l}\text { Ca15. O que é particularmente importante } \\
\text { para os acionistas privados? Para o } \\
\text { pequeno investidor, a nova regulamentação } \\
\text { para transações no mercado de futuros é } \\
\text { importante. Até o momento, ele podia } \\
\text { rescindir tais transações em caso de perdas, } \\
\text { desde que antes não tivesse assinado } \\
\text { nenhuma declaração de risco junto ao seu } \\
\text { banco ou o prazo de vigência da declaração } \\
\text { tivesse expirado. }\end{array}$ \\
\hline
\end{tabular}

Ca16. Damals hatten Christo und

Jeanne-Claude gerade das

Reichstags-Gebäude in eine

Theaterkulisse, den Vorplatz in eine

Flaniermeile verwandelt. Auch Götz

Hoeppe gab seinem Studienleben nochmals eine neue Richtung: Denn

um nur in das Mikroskop

beziehungsweise ein Sternenrohr zu schauen, hatte Götz Hoeppe auf seiner gerade beendeten Weltreise zu viel gesehen.

(http://archiv.tagesspiegel.de/archiv/1 6.04.2003/528299.asp - Anexado em 03/06/2007)
Ca16. Na ocasião, Christo e Jeanne-Claude tinham transformado justamente o prédio do parlamento alemão em um bastidor de teatro, o átrio, em um passeio. Também Götz Hoeppe deu mais uma vez à sua vida de estudos uma nova direção: pois para olhar somente através do microscópio ou do telescópio, ele tinha visto coisas em demasia na sua recém-concluída viagem pelo mundo.
Ca17. Jetzt können Sie sich vorstellen, was in einem großen Frauenversteher, wie ich seit Jahren einer bin, vorgeht, wenn er so etwas sieht beziehungsweise sich ansehen muss. Ich hätte nach ein, zwei Folgen abgebrochen, aber Ihnen zuliebe habe ich weitergemacht, bis zum bitteren Ende. (http://www.tagesspiegel.de/kultur/archiv/0 7.04.2003/515418.asp - Anexado em $03 / 06 / 2007$ )
Ca17. Agora você pode imaginar o que acontece com um grande entendedor de mulheres, como sou há anos, quando deve ver ou observar algo assim. Eu teria parado depois de um, dois episódios, mas em consideração a você continuei até o amargo final. 
Ca18. Am Sonntag um 5 Uhr früh beginnt die Polizei mit kostenpflichtigen Umsetzungen jener Autos, die in den zusätzlich eingerichteten

Halteverbotszonen geparkt worden sind. Das Umsetzen kostet für den Halter des Fahrzeuges 168 Euro. Die einzige Möglichkeit, während der Veranstaltung mit dem Auto aus dem Rundkurs herausoder in ihn hineinzufahren, besteht an der Lewisham- beziehungsweise

Brandenburgischen Straße. Denn der Tunnel unter dem Adenauerplatz ist für den Verkehr geöffnet. (http://www.tagesspiegel.de/berlin/archiv/0 5.04.2003/512848.asp - Anexado em $03 / 06 / 2007)$

Ca19. Die Handwerker sind los. Am Montag wollen sie zu Fuß und im Auto protestieren, unter dem Motto: ,Jetzt reicht's - Handwerk gegen Stillstand“. Aus ganz Deutschland wollen Maurer, Maler und Bäcker in Richtung Hauptstadt reisen. Sie werden dann auf Autobahnrastplätzen von der Polizei in Empfang genommen und später im Konvoi in die Berliner Innenstadt geleitet. Treffpunkte sind die Parkplätze Waldeck an der A 113 und Dreilinden an der Avus (um 7 Uhr). Jeweils etwa 100 Fahrzeuge starten dann als geschlossener Konvoi über die Avus und den

Kaiserdamm beziehungsweise über das Adlergestell Richtung Karl-LiebknechtStraße in Mitte.

(http://www.tagesspiegel.de/berlin/archiv/0 8.02.2003/429308.asp - Anexado em 05/06/2007)
Ca18. Às cinco horas da manhã do domingo, a polícia inicia o remanejamento pago dos carros deixados nas zonas adicionais onde se instituiu estacionamento proibido. Durante o evento, a única possibilidade de sair ou entrar de carro no circuito consiste nas ruas Lewisham ou Brandenburgische, pois o túnel sob a Adenauerplatz está aberto ao trânsito.
Ca20. Nach der einschlägigen Verordnung über die gymnasiale Oberstufe hängt die Zulassung zum Abitur davon ab, ob ein Schüler in jedem Halbjahr einen Grundkurs in Sport besucht hat. Eine Note sechs besagt aber, dass man den Kurs nicht besucht beziehungsweise nicht bestanden hat.(http://www.tagesspiegel.de/berlin/arch
Ca19. Os artesãos estão à solta. $\mathrm{Na}$ segunda-feira, eles querem protestar a pé e de carro com o lema "Agora basta artesanato contra a estagnação". De toda a Alemanha, pedreiros, pintores e padeiros querem viajar em direção à capital. Serão então recepcionados pela polícia em locais à beira da estrada e mais tarde conduzidos em comboio para o centro de Berlim. Os pontos de encontro são os estacionamentos Waldeck na A 113 e Dreilinden na Avus (às 7 horas.) Comboios fechados com mais ou menos 100 veículos cada partem então via Avus e Kaiserdamm ou Adlergestell sentido rua Karl-Liebknecht em Mitte.
Ca20. Segundo a portaria referente ao curso ginasial superior, a matrícula para o Abitur está condicionada ao fato de o aluno ter freqüentado em cada semestre um curso básico de educação física. Uma nota seis significa, porém, que a pessoa não frequientou o curso ou que não foi aprovada. 
iv/08.02.2003/430246.asp - Anexado em

05/06/2007)

Ca21. Wenn der Dollar schwächer ist als der Euro, entstehen Währungsverluste. Mit dem Kauf einer Währungsoption erwerben die Unternehmen das Recht, einen bestimmten Währungsbetrag zum festgelegten Kurs beziehungsweise Preis zu einem festgelegten Zeitpunkt in der Zukunft zu verkaufen. Ihre Verluste bleiben dann auf den gezahlten Optionspreis begrenzt. Der Maximalverlust tritt dann ein, wenn zum festgelegten Verfallstermin der Euro-Dollar-Kurs über dem festgelegten Kurs beziehungsweise Preis liegt. Dieses Restrisiko muss das Unternehmen tragen.

(http://www.tagesspiegel.de/wirtschaft/arch iv/31.01.2003/417528.asp - Anexado em 05/06/2007)

Ca22. Zwei Journalisten des Magazins hatten dieses angebliche Zitat nach der Sondersitzung des Parlaments zur Flutkatastrophe zufällig an einem Nebentisch im Bundestags-Restaurant gehört. Ob das "Spiegel"-Zitat der Wahrheit entspricht, hatte Kohl in seiner Erläuterung weder bestätigt noch dementiert. Der Alt-Kanzler hatte dem "Spiegel" unseriöse Praktiken vorgeworfen. Es sei ein "unerträglicher Zustand, dass private Gespräche im Bundestags-Restaurant von Journalisten belauscht beziehungsweise abgehört" würden, schrieb er. Göring war in der NaziZeit (1933 bis 1945) Reichstagspräsident und einer der führenden Köpfe der Nationalsozialisten. (http://www.abendblatt.de/daten/2002/09/0 5/65745.html - Anexado em 05/06/2007)
Ca21. Quando o dólar está mais fraco do que o euro, surgem perdas decorrentes da desvalorização monetária. Com a compra de uma opção de moeda, as empresas adquirem o direito de vender uma determinada quantia (de moeda) a um câmbio ou preço predeterminado em uma data futura predeterminada. Suas perdas ficam, então, limitadas ao preço de opção pago. A perda máxima ocorre quando, na data de vencimento estipulada, o câmbio euro-dólar está acima do câmbio ou preço estipulado. A empresa precisa arcar com esse risco residual.
Ca22. Dois jornalistas da revista haviam ouvido por acaso essa suposta citação após a sessão extraordinária do Parlamento referente à inundação, sentados em uma mesa vizinha no restaurante do Parlamento Federal. Em seu comentário, Kohl não desmentiu nem confirmou se a citação da "Spiegel" corresponde à verdade. O exchanceler acusou a revista de não ter uma prática séria. É “intolerável que jornalistas espreitem ou escutem às escondidas conversas privadas no restaurante do Parlamento", escreveu ele.

Na época do Nazismo (1933 a 1945), Göring foi presidente do Parlamento alemão e um dos líderes dos nacionalsocialistas. 


\section{Subtipo Cb: Alternativas não-excludentes}

Assim como no Tipo A (relação biunívoca), aqui também são estabelecidas relações entre diversos elementos unidos através de bzw. No entanto, ao contrário do que ocorre no tipo $\mathrm{A}$, a relação não fica totalmente explicitada. Ao invés de dois elementos ligados a outros dois em uma relação $\mathrm{AaBb}$, há as seguintes possibilidades:

a) um elemento interage com diversas opções $(A \rightarrow a, b, c \ldots): 0$ primeiro elemento é apresentado como um todo e o modo como ele se relaciona com as diversas possibilidades que Ihe são atribuídas através de bzw. não é explicitado. Como exemplos desta constelação, podem-se citar as ocorrências Cb9, com "terrorismo" dividindo-se em "social /nacional"; Cb12, com "blogs" para "acompanhar / comercializar livros"; Cb28, onde o "objetivo" é "tornar imunes a surpresas / obter vantagens"; Cb31, na qual o "valor mínimo" pode ser "120 / 165 / 205 euros"; Cb35, onde "preceitos" "complementam / alteram" a ordem básica. A este grupo pertencem as ocorrências $\mathrm{Cb} 1, \mathrm{Cb} 3, \mathrm{Cb} 7, \mathrm{Cb} 9, \mathrm{Cb} 10, \mathrm{Cb} 12$, Cb13, Cb14, Cb15, Cb16, Cb18, Cb19, Cb21, Cb24, Cb26, Cb28, Cb29, Cb30, Cb32, Cb34, Cb35, Cb36, Cb38, perfazendo 59\% do total de ocorrências do subtipo $\mathrm{Cb}$.

b) dois elementos interagem com duas opções, mas sem especificar a relação entre eles $(A B \rightarrow a b)$ : Este caso se diferencia do tipo de uso $A$ (relação biunívoca $\mathrm{AaBb}$ ), na qual é expresso claramente qual elemento realiza cada ação. Neste subtipo $\mathrm{Cb}$, as relações não são explicitadas, mas continuam marcadas como ações distintas, realizadas por elementos distintos. Alguns exemplos do corpus são: "dois pais / contrato para berçário ou creche" (Cb4); "neonazistas e extremistas de direita / protestar e agradecer" (Cb11); "dois homens / penas de 25 e 50 anos" (Cb27); "governo federal, comunidade / 50, 90\% dos custos" (Cb37). Este grupo engloba as ocorrências Cb4, Cb8, Cb11, Cb27, Cb37, com $13 \%$ do total de ocorrências do subtipo $\mathrm{Cb}$. 
C) vários elementos interagem com uma ou mais opções, sem especificar a relação entre eles (A(,B,C...) $\square$ a(,b,c...)): Aqui, vários elementos são apresentados como dois grupos e bzw. marca o fato de que os elementos do primeiro grupo se relacionam de diversas maneiras com os elementos do segundo, embora não fique claro como. Alguns exemplos do corpus são "Alemanha, Áustria, Turquia / dinheiro, armas" (Cb5); "colesterol, mecanismos inflamatórios, radicais livres / coração, vasos, arteriosclerose" (Cb6); "ajuda humanitária, reconstrução, melhorias / financiamento" (Cb25); "Lenhart, Mahlknecht, Picelli, Trippa / espaço Meran" (Cb33). Neste grupo se encontram as ocorrências Cb2,Cb5, Cb6, Cb17, Cb20, Cb22, Cb23,Cb 25, Cb31, Cb33, Cb39, representando $28 \%$ do total de ocorrências do subtipo $\mathrm{Cb}$.

O subtipo $\mathrm{Cb}$ apresentou as seguintes possibilidades de tradução para 0 português:

\begin{tabular}{|c|c|c|}
\hline & ocorrências & porcentagem \\
\hline $\mathrm{e}$ & 31 & $79 \%$ \\
\hline e/ou & 7 & $18 \%$ \\
\hline ou ainda & 1 & $3 \%$ \\
\hline
\end{tabular}

Os três grupos do subtipo $\mathrm{Cb}$ identificados anteriormente como "a, b e c", não tiveram influência sobre a tradução para o português, sendo que a tradução "e" foi responsável por cerca de $80 \%$ em todos os grupos. Os $20 \%$ restantes representam a tradução "e/ou" nos grupos a e b e, no grupo c, dividem-se igualmente por "e/ou" e "ou ainda" (uma ocorrência de cada). Dessa forma, pode-se afirmar que a tradução "e" é prototípica para o subtipo de uso Cb.

Em todas as ocorrências deste subtipo de uso, a indicação específica da relação entre elemento e opção é colocada em um segundo plano em relação aos agentes e aos fatos em si. Esse apagamento da especificação de relações permite que, em português, bzw. seja traduzido com maior freqüência por "e" (79\% do total), marcando apenas a formação de um conjunto composto por várias opções, que é relacionado como um todo a um ou mais elementos. 
No entanto, o uso de bzw. em alemão continua apontando que as ações acontecem de modo alternado, quando originadas do mesmo elemento, ou que se originam de elementos diferentes que as realizam separadamente, mesmo que a relação não seja especificada completamente. Esse traço se perde na tradução em português, ficando totalmente dependente do contexto.

Há ainda a possibilidade de utilizar a expressão "e/ou" para traduzir bzw. nestes contextos específicos (18\%). A expressão "e/ou" deixa em aberto se o conteúdo dos elementos conectados deve ser considerado como alternativo ou comum. Desse modo, mantém-se a alternatividade expressa por "ou", mas eliminando o seu efeito de exclusão (cf. PASCH 2003: 455s), ao mesmo tempo que se minimiza o efeito de conjunto homogêneo criado por "e".

A forma "ou ainda" foi utilizada apenas uma vez em todo o corpus da pesquisa, o que leva a crer que seja uma variante estilística condicionada a um contexto particular. Neste caso específico, pode-se especular que "ainda" atua como um elemento aditivo adicionado ao "ou", funcionando, assim, quase como "e/ou".

As ocorrências do subtipo $\mathrm{Cb}$ no corpus estão listadas a seguir, organizadas de acordo com sua tradução para o português.

Cb1. Mitte Mai. Das Arbeitsamt müllt mich mit weiteren Anfragen von Personalvermittlungs- bzw. Zeitarbeitsfirmen voll. Genervt schicke ich also meine liederlichen ("liederlich" war das Lieblingsadjektiv meines Großvaters und passt hier wirklich haargenau) Woolworthmappen in die Welt. Einige Agenturen haben sich bereits telefonisch gemeldet, zwei mit der Bitte um Rückruf auf meinem Anrufbeantworter. Ich habe diese Nachrichten einfach gelöscht. Anrufbeantworter funktionieren ja häufig nicht.

(http://www.tagesspiegel.de/politik/;art771, 1946958 - Anexado em 06/06/2007)
Cb1. Meados de maio. A Secretaria do Trabalho me enche com mais solicitações de agências de intermediação de pessoal $\underline{\mathbf{e}}$ de trabalho temporário. Irritado, enviei então ao mundo as desmazeladas ("desmazelado" era o adjetivo preferido de meu avô e realmente cai como uma luva aqui) pastas da Woolworth. Algumas agências já se manifestaram por telefone, duas deixaram recado na secretária eletrônica pedindo que eu retornasse a ligação. Simplesmente apaguei esses recados. Secretárias eletrônicas muitas vezes não funcionam. 
Cb2. Unsere Mega bzw. Gigaprominenten entschweben immer höher in den metaphorischen Raum. Ist Bohlen der Möllemann des Show-Biz? Schumi der Ralph Siegel des Rennwesens, Effenberg die Titanic des Weltfußballs? Oder ist der eher der Lafontaine der Bundesliga? 80000 Stück seiner Lebenserinnerungen „Ich hab's allen gezeigt" sind bereits bestellt von wem?

(http://www.tagesspiegel.de/meinung/kom mentare/Kommentare; art141,2270588 Anexado em 06/06/2007)
Cb2. Nossos mega e gigaproeminentes pairam cada vez mais alto na sala metafórica. Bohlen é o Möllemann do show biz? Schumi o Ralph Siegel das corridas, Effenberg o Titanic do futebol mundial? Ou ele é o Lafontaine do Campeonato Alemão? 80.000 exemplares de seu livro de memórias "Ich hab's allen gezeigt" [eu mostrei a eles] já estão encomendados - por quem?
Cb3. Ein abenteuerlicher Gedanke. Wenn „Was macht die Welt?" die

Bundesregierung wäre, würde es deutsche Soldaten auf keinen Fall auf eine Mission schicken, die etwa dem Herumwedeln mit einer ungeladenen Pistole entspräche.

Denn: Wer Soldaten entsendet, muss bereit sein zu kämpfen. Dazu muss er gerüstet sein $\underline{\text { bzw. }}$. erst gar nicht in eine Situation geraten, in der die andere Seite militärisch überlegen bleibt. Also muss man sich diese Überlegenheit selbst erschaffen, am besten, indem man so massiv in das Land einfällt, dass der andere gar erst nicht auf dumme Gedanken kommt.

(http://www.tagesspiegel.de/politik/;art771, 2003675 - Anexado em 06/06/2007)
Cb3. Um pensamento ousado. Se "O que o mundo faz" fosse o governo federal, soldados alemães não seriam enviados de forma alguma em uma missão que corresponderia a apontar para todos os lados com uma pistola descarregada. Visto que: quem envia soldados deve estar pronto para lutar.

Para tal, deve estar equipado e jamais cair em uma situação na qual o outro lado seja militarmente superior. Portanto, é preciso criar a própria superioridade, de preferência no momento da invasão maciça do país, de modo que o outro sequer pense em fazer bobagens.
Cb4. Ob das Rathaus mit den Plänen durchkommt, ist indes fraglich. Zum einen prüft das Regierungspräsidium Dresden im Auftrag der Landesregierung die Rechtmäßigkeit der Einschnitte. Dabei gehe es insbesondere um die Zulässigkeit der Kündigung laufender Verträge, hieß es im Sozial- und im Innenministerium, wo angesichts der kommunalen Finanznot gleichwohl »Verständnis für das Setzen von Prioritäten bei der Vergabe von Betreuungsplätzen « geäußert wurde. $\mathrm{Ob}$ und in welchem Umfang die Stadt tatsächlich Plätze bereitstellen muss, ist
Cb4. Entretanto, é incerto se a prefeitura vai conseguir aprovar seus planos. Por exemplo, a presidência de Dresden verifica, a pedido do governo do Estado, a legitimidade dos cortes. Nesse caso, tratase sobretudo da admissibilidade de rescisão dos contratos vigentes, supostamente no Ministério Social e no Ministério dos Negócios Interiores onde, apesar da dificuldade financeira do município, foi expresso "entendimento para priorizar a abertura de vagas em creches". É polêmico se e em que extensão a cidade deve de fato disponibilizar vagas. Na Saxônia, crianças 


\begin{tabular}{|c|c|}
\hline $\begin{array}{l}\text { Stritt } \\
\text { drei } \\
\text { Betre } \\
\text { Pflic } \\
\text { »bed } \\
\text { gewä } \\
\text { defin } \\
\text { Vor } \\
\text { Elter } \\
\text { PDS } \\
\text { mitte } \\
\text { Krip } \\
\text { abge } \\
\text { Rech } \\
\text { Schri } \\
\text { Stadt } \\
\text { zurü } \\
\text { zu Ja } \\
\text { werd } \\
\text { bezei } \\
\text { versp } \\
\text { vom } \\
\text { über } \\
\text { abge }\end{array}$ & $\begin{array}{l}\text { com menos de três anos de idade não têm } \\
\text { direito a creche. Entretanto, faz parte das } \\
\text { obrigações do município garantir uma } \\
\text { "oferta que atenda a demanda". } \\
\text { Como definir tal demanda é algo que deve } \\
\text { ser aclarado esclarecido agora. } \\
\text { Mas sobretudo os pais prejudicados } \\
\text { combatem as rescisões. Como informou } \\
\text { Falk Neubert, deputado do PDS na } \\
\text { assembléia estadual, dois pais que } \\
\text { fecharam um cujo contrato para berçário e } \\
\text { creche venceram já incumbiram um } \\
\text { advogado da preparação dos procedimentos } \\
\text { legais. Por ora, o município foi intimado a } \\
\text { revogar as rescisões. Se isso não ocorrer, } \\
\text { deve ser dada entrada em uma ação judicial } \\
\text { no início do ano. O advogado Andreas } \\
\text { Boine descreveu a ação como } \\
\text { "promissora". Por isso, os pais ainda não } \\
\text { deveriam entregar o atestado exigido pela } \\
\text { prefeitura referente à profissão. }\end{array}$ \\
\hline
\end{tabular}

Cb5. Einstweilen werden

Stellvertreterkriege geführt: Nicht nur auf dem Balkan, wo die Triple Entente aus Frankreich, England und Rußland das Kräftegleichgewicht im jugoslawischen Nachfolgekrieg bewahren will, während die Mittelmächte Deutschland-Östereich und die Türkei ihre Kettenhunde Izetbegovic und Tudjman mit Geld bzw. Waffen füttern. Auch am Kaukasus wird gekämpft, es geht um die Ölvorkommen am Kaspischen Meer, die zweitgrößten der Welt. (http://www.comlink.de/clhh/m.blumentritt/agr77.htm - Anexado em 12/06/2006)

Cb6. Balsam für Leber und Gefäßer

Curcuma hat neben seiner verdauungsregulierenden Eigenschaften auch positive Auswirkungen auf den
Cb5. Por ora, estão ocorrendo guerras por procuração: Não apenas nos Bálcãs, onde a tríplice aliança formada pela França, Inglaterra e Rússia quer preservar o equilíbrio de forças na guerra de sucessão iugoslava enquanto as potências centrais Alemanha, Áustria e Turquia alimentam seus mastins Izetbegovic e Tudjman com dinheiro e armas. Há disputa também no Cáucaso, trata-se das jazidas de petróleo no Mar Cáspio, as segundas maiores do mundo.
Cb6. Bálsamo para fígado e vasos

A cúrcuma, juntamente com suas propriedades reguladoras da digestão, tem também efeitos positivos sobre o 


\begin{tabular}{|c|c|}
\hline $\begin{array}{l}\text { Leberstoffwechsel. Neben einer Senkung } \\
\text { des schädlichen LDL-Cholesterins schützt } \\
\text { Curcuma die Leber vor schädlichen } \\
\text { Radikalen, die durch Krankheit, Alkohol, } \\
\text { Zigarettenrauch oder Umweltgifte entstehen } \\
\text { und mindert Entzündungsprozesse. } \\
\text { Cholesterin, Entzündungsmechanismen und } \\
\text { Radikale schädigen Herz und Gefäße bzw. } \\
\text { fördern die Entstehung von Arteriosklerose. } \\
\text { Auch das Krebswachstum kann durch } \\
\text { Radikale beschleunigt werden. } \\
\text { (http://www.temmler- } \\
\text { online.de/temmleronline/editionen/rubrik_d } \\
\text { ruck/temmler/16/ - Anexado em } \\
\text { 12/06/2007) }\end{array}$ & $\begin{array}{l}\text { metabolismo do fígado. Além de reduzir o } \\
\text { mau colesterol (LDL), a cúrcuma protege o } \\
\text { fígado dos radicais nocivos que surgem } \\
\text { devido a enfermidades, álcool, cigarro ou } \\
\text { toxinas ambientais e diminui processos } \\
\text { inflamatórios. Colesterol, mecanismos } \\
\text { inflamatórios e radicais livres prejudicam o } \\
\text { coração e os vasos e promovem o } \\
\text { surgimento da arteriosclerose. O } \\
\text { desenvolvimento do câncer também pode } \\
\text { ser acelerado pelos radicais livres. }\end{array}$ \\
\hline
\end{tabular}

Cb7. Toshiba Infinix VCi

Das einfach zu bedienende Infinix VCi

Angiographiesystems mit Längs- und

Querverschiebung erlaubt die komplette

Abdeckung für alle Untersuchungen von

Kopf bis Fuß bei ruhenden Patienten. Der

C-Bogen kann links, rechts und kopfseitig

positioniert werden. Dieses besonders hohe

$\mathrm{Ma} ß$ an Bewegungsfreiheit des C-Bogens

wird gekoppelt mit dem Toshiba

Hyperhandle, der die ,Einhand-Bedienung'

von C-Bogen und Rechnersystem

ermöglicht und dem Untersucher immer

eine freie Hand für den Katheter lässt. Das

System bietet umfassende Möglichkeiten

sowohl für Routineuntersuchungen wie

auch für spezialisierte interventionelle

Anwendungen. Die gittergesteuerte

Röntgenröhre in Verbindung mit der

innovativen Tantal-Filtertechnologie und 4

Dosisleistungslevel für Durchleuchtung

bzw. Aufnahme erlauben ein Höchstmaß

an Variabilität in der Dosisreduzierung bei

hervorragender Bildqualität. Die

,Sequentielle Navigation' entlastet den

Anwender von Routineeinstellungen so

dass er seine Konzentration

uneingeschränkt dem Patienten und der

Intervention zuwenden kann.

(http://www.radiologieforum.de/Categories

/Category228.aspx - Anexado em $12 / 06 / 2007)$

\section{Cb7. Toshiba Infinix Vci}

Simples de operar, o Infinix Vci Sistemas de Angiografia com deslocamento longitudinal e transversal permite cobertura completa em todos os exames da cabeça aos pés em pacientes inativos. $\mathrm{O}$ braço $\mathrm{C}$ pode ser posicionado à esquerda, à direita $\mathrm{e}$ ao lado da cabeça. Esse grau especialmente elevado na liberdade de movimentação do braço C é combinado com o Toshiba

Hyperhandle, que possibilita o "manejo maneta" do braço $\mathrm{C}$ e do computador, sempre deixando o examinador com uma mão livre para manusear o cateter. $\mathrm{O}$ sistema oferece amplas possibilidades tanto para exames de rotina como para intervenções especializadas. O tubo de raio-x regulado por grade juntamente com a inovadora tecnologia de filtro de tântalo e 4 níveis de dosagem para fluoroscopia $\underline{\mathbf{e}}$ filmagem permitem o máximo de variabilidade na redução da dose, para a obtenção de uma excelente qualidade de imagem. A "navegação seqüencial" desobriga o usuário dos ajustes de rotina, de modo que ele pode devotar sua concentração sem restrições ao paciente e à intervenção. 
Cb8. Fehlende positive Forderungen

Dementsprechend wurden durch die Gewerkschaftsführung praktisch keine positiven Forderungen gegen die Kahlschlagspolitik von Regierung und Kapital gestellt, geschweige denn eine offene Diskussion in der Mitgliedschaft organisiert, wie zum Beispiel: Rente mit 60 bzw. 55, 30 Stundenwoche, 10 Euro Mindestlohn, Rücknahme der Agenda 2010 mitsamt den Repressionen gegen Hartz IV-Empfänger, die Forderung nach Übernahme der Sozialversicherungskosten durch die Unternehmer, kostenloser Gesundheitsvorsorge, Schaffung von Ausbildungsplätzen usw. (http://www.trueten.de/categories/40Soziales?PHPSESSID=67d11bc5e0cff $4 \mathrm{f} 9 \mathrm{f}$ 5 ccec29eeadefe3 - Anexado em $12 / 06 / 2007$ )
Cb8. Ausência de reivindicações positivas Nesse sentido, por meio da liderança sindical não foi apresentada praticamente nenhuma reivindicação positiva contra a política de cortes do governo e do capital, isso sem mencionar a falta de uma discussão aberta com a sociedade. Por exemplo: aposentadoria aos $60 \underline{\text { e } 55,30}$ horas semanais, salário mínimo de 10 euros, abandono da agenda de $2010 \mathrm{com}$ repressão aos beneficiários do Hartz IV, exigência de aceitação dos custos da seguridade social pelos empresários, de assistência médica gratuita, da criação de centros de treinamento, etc.

\section{Cb9. Terror als Kriegführung}

Die jüngeren Formen des transnationalen

Terrorismus unterscheiden sich in organisatorischer, logistischer und operativer Hinsicht so sehr von dem skizzierten Modell des herkömmlichen national- bzw. sozial-revolutionären Terrorismus, dass die gemeinsame Benennung als ,Terrorismus“ eher irreführend als erhellend ist. Letzten Endes bezieht sie sich allein auf die unmittelbare Funktion der Anschläge, nämlich die Verbreitung von Angst und Schrecken. (http://www.internationalepolitik.de/archiv/ jahrgang2004/februar04/terrorismus-heute-die-asymmetrisierung-des-krieges.html Anexado em 12/06/2007)
Cb10. URTEILE IN DER SACHE STRELETZ, KESSLER UND KRENZ UND IN DER SACHE K.-H. W. GEGEN DEUTSCHLAND

Die Grosse Kammer des Europäischen Gerichtshofs für Menschenrechte hat am 22. März 2001 in zwei Urteilen entschieden, dass Deutschland durch die

\section{Cb9. Terror como beligerância}

As mais novas formas do terrorismo transnacional, no aspecto organizacional, logístico e operacional, diferem tanto do modelo convencional de terrorismo revolucionário social e nacional que a denominação comum "terrorismo" está mais para enganosa do que esclarecedora. Afinal, ela se refere somente à função imediata dos ataques, a saber, a propagação do medo e horror.
Cb10. SENTENÇAS NO CASO STRELETZ, KESSLER E KRENZ E NO CASO K.-H. W. VERSUS ALEMANHA

A Grande Câmara do Tribunal Europeu dos Direitos Humanos decidiu em 22 de março de 2001, em dois julgamentos, que através da condenação de altos funcionários da 
Verurteilung von hohen DDR-

Funktionären bzw. eines DDR-

Grenzsoldaten wegen Tötungsdelikten an der Grenze zwischen den beiden deutschen Staaten Artikel 7 Abs. 1 der Europäischen Menschenrechtskonvention nicht verletzt hat. Im Fall Streletz, Kessler und Krenz erging das Urteil einstimmig, im Fall K.-H. W. mit 14 zu 3 Stimmen. In beiden Urteilen wurde ferner einstimmig entschieden, dass keine Diskriminierung vorliegt, die Artikel 14 in Verbindung mit Artikel 7 der Konvention widerspricht. (http://www.staatshehlerei.org/eu/krenz_1. htm - Anexado em 12/06/2007)
RDA $\underline{\mathbf{e}}$ de um soldado da fronteira devido a homicídios na fronteira entre os dois países alemães a Alemanha não violou o artigo 7, parágrafo 1, da Convenção Européia de Direitos Humanos. No caso Streletz, Kessler e Krenz a decisão foi unânime, no caso K.-H. W. foram 14 votos a 3. Em ambos os julgamentos, determinou-se também por unanimidade que não há nenhuma discriminação violando o artigo 14 juntamente com o artigo 7 da Convenção.
Cb11. Österreich läßt Neonazi am

Heldenplatz aufmarschieren

Von Karl Pfeifer

Rund 150 Neonazis und Rechtsextreme versammelten sich am 13.4. am Wiener Heldenplatz, um gegen die Ausstellung "Verbrechen der Wehrmacht 1941-1944" zu demonstrieren bzw. auf Transparenten ihren "Großvätern" zu danken. Am gleichen Heldenplatz brüllten am 15. März 1938 hunderttausende Österreicher "Ein Volk, ein Reich, ein Führer" und "Sieg Heil", nachdem Adolf Hitler den Anschluss seiner Heimat an das "Dritte Reich" bekanntgab.

(http://www.judentum.net/europa/heldenpl atz.htm - Anexado em 12/06/2007)
Cb11. Áustria deixa neonazistas se reunirem na Praça dos Heróis Por Karl Pfeifer

Cerca de 150 neonazistas e extremistas de direita se reuniram no dia 13 de abril na Praça dos Heróis em Viena para protestar contra a exposição "Crime das Forças Armadas Alemãs 1941-1944” e agradecer seus "avós" com faixas. Na mesma Praça dos Heróis em 15 de março de 1938, centenas de milhares de austríacos gritaram "Um povo, um império, um líder" e "Sieg Heil", depois que Adolf Hitler anexou sua pátria ao "Terceiro Reich".
Cb12. Blogs, die später als „klassisches Buch" veröffentlicht wurden, gibt es bereits seit geraumer Zeit. Man bezeichnet diese auch als Blook (Weblog + Book = Blook). Gleiches gilt für Bücher, die in einem Weblog entwickelt wurden. Dabei verfasst der Autor jeden Tag ein neues Kapitel. Nach der Fertigstellung ist das gesamte Werk häufig ebenfalls in der Buchhandlung erhältlich. Auch ein Blog zur Begleitung bzw. Vermarktung eines Buches ist nichts Neues.

(http://guerillamarketingbuch.com/ Anexado em 12/06/2007)
Cb12. Blogs, que mais tarde foram anunciados como "livro clássico", já existem desde muito tempo. São chamados também de Blook (Weblog + Book = Blook). O mesmo vale para livros produzidos em weblogs. Neste caso, a cada dia o autor redige um novo capítulo.

Depois de concluída, a obra completa costuma também ser vendida nas livrarias. Tampouco são novidade os blogs para acompanhar e comercializar livros. 
Cb13. Ich hätte nichts dagegen, tausend Menschen wie mich zu reproduzieren, weil ich glaube, dass die Welt sie braucht. Aber ich wäre ganz entschieden gegen auch nur einen weiteren Herr Täuschleer, meinen Nachbarn. Er ist ein unmöglicher Mensch. Er wäscht nie seinen Daimler, zweifelt an der Berechtigung von Kehrwochen. Er lässt seinen Hund im ganzen Viertel frei herumlaufen und wenn man nach den leeren Flaschen in seinem Mülleimer geht, trinkt er hier in Stuttgart nur badischen Wein. Irgendwas stimmt nicht mit seinen Genen und wenn wir seine Zellen zum Klonen freigeben würden, wäre in unserem Viertel der Teufel los. Andererseits gibt es die schöne Frau Sommer mit den "Supergenen" bzw. Maßen 95/60/95. Sie arbeitet in der gleichen Firma wie ich. (http://www.zeit.de/2003/03/leserbrief_hid y - Anexado em 12/06/2007)
Cb13. Eu nada teria contra reproduzir milhares de pessoas como eu porque acho que o mundo precisa delas. Mas eu seria enfaticamente contra mais um Sr.

Täuschleer, meu vizinho. Ele é impossível. Nunca lava o seu Daimler, desconfia da legitimidade do rodízio de tarefas. Deixa o cachorro correr solto por toda a vizinhança e, se alguém observar as garrafas vazias na sua lixeira, aqui em Stuttgart ele bebe apenas vinho de Baden. Há algo errado com os seus genes e, se liberássemos suas células para clonagem, nosso bairro seria um inferno. Por outro lado, há a bela senhora Sommer com "supergenes" $\underline{\mathbf{e}}$ medidas 95/60/95. Trabalhamos na mesma empresa.
Cb14. In dieser Arbeit soll gezeigt werden, inwieweit „Labyrinth der Welt und das Paradies des Herzens" von Comenius als Vorform des utopischen Romans gesehen werden kann. Bevor ich auf diese Frage eingehe, möchte ich zunächst einmal erläutern, was im Rahmen dieser Arbeit unter Utopie bzw. Antiutopie zu verstehen ist und kurz die Entwicklung dieser beiden literarischen Gattungen darstellen. (http://www.hausarbeiten.de/faecher/vorschau/1 4390.html - Anexado em 12/06/2007)
Cb14. Neste trabalho deve ser mostrado até que ponto "Labirinto do Mundo e o Paraíso do Coração" de Comenius pode ser visto como forma primária do romance utópico. Antes que eu entre nesta questão, gostaria primeiramente de esclarecer o que, no âmbito deste trabalho, deve ser entendido como utopia e anti-utopia e descrever de forma breve o desenvolvimento desses dois gêneros literários.
Cb15. Früher war ich ein totaler Gegner der Rechtschreibreform. Doch im Laufe der vergangenen zwei Jahre ist mir klargeworden, dass (daß) sie auch viele Erleichterungen enthält. Hiermit möchte ich darauf hinweisen, dass (daß) ich mittlerweile von der neuen

Rechtschreibung überzeugt bin, weil sie viele logische Erleichterungen für uns enthält. Zum Beispiel rauh bzw. rau; nummerieren bzw. numerieren, oder war's andersherum?

(http://images.zeit.de/text/1998/42/199842.
Cb15. Antigamente eu era um opositor ferrenho à reforma ortográfica. Mas, no decorrer dos últimos dois anos, ficou claro para mim que (dass $x$ da $\beta$ ) ela também traz muitas simplificações. Quero mostrar aqui que, desde então, estou satisfeito com a nova reforma, por ela nos trazer muitas simplificações lógicas. Por exemplo, rauh $\underline{\mathbf{e}}$ rau, nummerieren e numerieren; ou era contrário? 
rechtschreibung_.xml - Anexado em

20/06/2007)

Cb16. Die Politik versucht seit Jahren dieses System zu gestalten. Sie ist dabei mit einem komplexen Geflecht konfrontiert, das gut organisiert die eigenen Interessen und Strukturen bewahren will und in zunehmenden Maße Reformen zu blockieren versucht. Die

Gesundheitspolitik der 90er hat mit Ausnahme des GSG bestenfalls zu Notreparaturen bzw. kurzfristigen Kostendämpfungen geführt. (http://library.fes.de/fulltext/asfo/01160.ht m - Anexado em 12/06/2007)

Cb17. Bis Ahmad wieder zu sprechen anhebt, leise jetzt und eindringlich. Für sie sei es kein Problem, mit Juden zusammenzuleben. Sie beanspruchten nur den Teil des Territoriums, der ihnen zusteht. Doch US-Amerika und Israel seien wie Bruder und Schwester. Weil jede Menge Israelis beziehungsweise ihre Verwandten auch in den USA lebten - als Wähler oder Politiker. "Bush hört nicht auf Gott, sondern auf Scharon!", sagt Ahmad mit einem Stoßseufzer.

(http://www.palaestina.org/news/beitraege/ zeigeBeitrag.php?ID=79 - Anexado em 31/05/2007)

Cb18.Unmittelbar nach seiner

Thronbesteigung ging Friedrich II. an die Umgestaltung beziehungsweise

Neubildung von Regimentern. Bei dieser Gelegenheit entstand aus dem 2. Bataillon des Ruppiner Regiments »Kronprinz « Nr. 15 das Regiment Nr. 34. Der König verlieh es (1742) seinem jüngsten Bruder Ferdinand und gab ihm dementsprechend den Namen: Regiment Prinz Ferdinand. (http://gutenberg.spiegel.de/fontane/mark/ mar021.htm - Anexado em 31/05/2007)
Cb16. A política tenta há anos moldar esse sistema. Nisso, ela se depara com uma rede complexa que organiza bem os próprios interesses, que quer preservar estruturas e que tenta bloquear reformas de forma crescente. Na melhor das hipóteses, a política de saúde dos anos 90 levou, com exceção do GSG, a reparos provisórios $\underline{\mathbf{e}}$ reduções de custo de curto prazo.
Cb17. Até Ahmad recomeçar a falar, agora em tom baixo e enérgico. Para eles não era um problema conviver com judeus. Eles apenas reivindicavam a parte do território que lhes compete. Mas os Estados Unidos e Israel eram como irmão e irmã, visto que grande número de israelenses e parentes moraram também nos Estados Unidos como eleitores ou políticos. "Bush não ouve a Deus, mas a Sharon!", disse Ahmad com um suspiro profundo. 
Cb19. Die entsprechende

Auffanggesellschaft wird oftmals von den

Gläubigern gegründet. Sie müssen für die

Übertragung des Unternehmens bezahlen

beziehungsweise auf ihre Forderungen

verzichten.

(http://www.tagesspiegel.de/wirtschaft/arch iv/08.04.2002/ak-wi-wi-449849.html -

Anexado em 01/06/2007)

Cb20. Insgesamt hatten die Organisatoren vom SCC Berlin die Rekordzahl von 14 709 Meldungen aus 49 Nationen registriert. Darunter waren neben Inlineskatern und Rollstuhlfahrern auch 1290 Schüler und Kinder, die bei Rennen über $4 \mathrm{~km}$ beziehungsweise $800 \mathrm{~m}$ an den Start gingen. "Wir sind glücklich über diesen neuen Teilnehmerrekord und zufrieden mit den Leistungen der Spitzenläufer. Ich hoffe, dass wir die Starterzahlen im nächsten Jahr wiederum um 20 Prozent steigern können", sagte Cheforganisator Horst Milde.

(http://www.tagesspiegel.de/sport/archiv/0 7.04.2002/ak-sp-5511586.html - Anexado em 01/06/2007)
Cb19. A sociedade correspondente que dá continuidade à empresa em dificuldades é freqüentemente fundada pelos credores. Eles devem pagar pela transferência da empresa $\underline{\mathbf{e}}$ renunciar à sua dívida ativa.
Cb20. No total, os organizadores do SCC Berlim haviam registrado o número recorde de 14.709 inscrições de 49 nações. Entre elas havia, além de patinadores e usuários de cadeira de rodas, também 1290 estudantes e crianças, que largaram na corrida de $4 \mathrm{~km} \underline{\mathbf{e}} 800$ metros. "Estamos felizes com esse novo recorde de participantes e satisfeitos com o desempenho dos principais corredores. Espero que no ano que vem possamos novamente elevar o número de competidores em 20\%", disse o organizador-chefe Horst Milde.
Cb21. Mit dem Fonds 12, der

Kündigungsgrund gegen Morgenroht, wurde in ein Wohnhaus in Buckow mit 121 Wohnungen investiert. Gutachter werfen dem Fonds-Management viel zu hohe Baukosten vor. Zudem habe die LBB später das Haus von der Gehag zu einem Kaufpreis übernommen, der weit über dem Verkehrswert liegen soll. Morgenroth sieht sich beziehungsweise den LBB-Vorstand völlig zu Unrecht beschuldigt. Klar ist, dass die Vorwürfe verjährt sind. Deshalb hatten Mitglieder des Aufsichtsrates versucht, den Banker zu überreden, selbst zu kündigen. (http://www.tagesspiegel.de/wirtschaft/arch iv/20.03.2002/ak-wi-4412458.html -

Anexado em 01/07/2007)
Cb21. Com o Fundo 12, motivo da demissão de Morgenroht, investiu-se em um prédio residencial em Buckow com 121 apartamentos. Peritos censuram a administração do fundo pelos elevados custos da construção. Além disso, o LBB mais tarde teria adquirido a casa da Gehag por um preço que deve estar bem acima do valor comercial. Para Morgenroth, a acusação contra ele $\underline{\mathbf{e}}$ a direção do LBB é totalmente ilegítima. É evidente que as acusações prescreveram. Por isso, membros do conselho administrativo haviam tentado convencer o executivo a pedir demissão. 
Cb22. Das Geld, das der Inhaber

beziehungsweise die Gesellschafter oder

Aktionäre ihrem Unternehmen zur

Verfügung stellen, wird Eigenkapital

genannt. Dabei kann es sich um das

persönliche Vermögen handeln oder

erwirtschaftete Gewinne, die reinvestiert

wurden.

(http://www.tagesspiegel.de/wirtschaft/arch iv/11.03.2002/ak-wi-4415553.html -

Anexado em 03/06/2007)
Cb22. O dinheiro que o proprietário e os sócios ou acionistas colocam à disposição da empresa é chamado de capital próprio. Nesse caso, pode-se tratar de patrimônio pessoal ou de lucros que foram reinvestidos.
Cb23. US-Außenminister Colin Powell hat bereits angekündigt, dass Washington die Einnahmen aus dem Öl-für-LebensmittelProgramm der UN für die Bezahlung des Wiederaufbaus nutzen will. Nach den geltenden Verträgen wäre dies jedoch rechtswidrig. Allein das irakische Volk beziehungsweise seine rechtmäßige Regierung können über die Gelder verfügen.

(http://www.tagesspiegel.de/politik/archiv/ 05.04.2003/512902.asp - Anexado em 03/06/2007)
Cb23. O ministro das Relações Exteriores dos Estados Unidos, Colin Powell, já anunciou que Washington quer utilizar a arrecadação do programa Petróleo por Alimentos, da ONU, para financiar a reconstrução. Segundo os contratos vigentes, isso, no entanto, seria ilegal. Somente o povo iraquiano e seu governo legítimo podem dispor do dinheiro.
Cb24. Als Reaktion auf das Arbeitsverbot wies der Chefredakteur von Al Dschasira, Ibrahim Helal, die sieben übrig gebliebenen Irak-Korrespondenten an zu pausieren. „Wir lassen uns nicht vorschreiben, wer im Irak arbeiten darf und wer nicht", sagt er. Der Deutschland-

Korrespondent des arabischen Nachrichtensenders, Aktham Suliman, sagt, dass Al Dschasira hofft, mit diesem Druckmittel die Ausweisung beziehungsweise das Arbeitsverbot rückgängig zu machen. (http://archiv.tagesspiegel.de/archiv/04.04. 2003/511560.asp - Anexado em 03/06/2007)

Cb25. Das geht aus einem detaillierten Dokument hervor, das der Nachrichtenagentur AP vorliegt. Insgesamt 4,2 Milliarden Dollar sollen dem Plan
Cb24. Em reação à proibição de trabalho, o editor-chefe da Al Jazira, Ibrahim Helal, ordenou aos sete correspondentes que restavam no Iraque que parassem. "Não aceitamos que ditem quem pode e quem não pode trabalhar no Iraque", disse ele. $\mathrm{O}$ correspondente alemão da emissora de notícias árabe, Aktham Suliman, disse que a Al Jazira espera com essa ameaça cancelar a expulsão e proibição de trabalho. 
zufolge für die innere Sicherheit

bereitgestellt werden, 7,8 Milliarden sind vorgesehen für die Unterstützung Israels, Afghanistans und anderer Verbündeter der USA. Auch humanitäre beziehungsweise Wiederaufbauhilfen für den Irak sowie die Verbesserungen des Schutzes für amerikanische Einrichtungen sollen mit diesem Finanzierungsprogramm abgedeckt werden.

(http://news.orf.at/030325-

60934/60936txt_story.html - Anexado em 03/06/2007)

Cb26. Grit Breuer (Magdeburg) war als einzige Sprinterin über $400 \mathrm{~m}$ dabei. Doch kein einziger Läufer stand im DLV-Team. Eine Reihe von Athleten haben dabei von vornherein auf die Hallen-Titelkämpfe beziehungsweise sogar auf die komplette Hallensaison verzichtet, um sich langfristiger auf die Weltmeisterschaften im August in Paris vorbereiten zu können. (http://www.sccevents.com/news/news001245.html Anexado em 03/06/2007) o plano, para a segurança interna, 7,8

bilhões estão previstos para auxiliar Israel,

o Afeganistão e outros aliados dos Estados Unidos.

Também a ajuda humanitária e a reconstrução do Iraque, bem como melhorias na proteção das instalações americanas, devem ser cobertas por esse programa de financiamento.
Cb27. Reinhard Wandtner zitiert zwei Studien (von Scott Atran in Science und von Alan Krueger und Jitka Maleckowa für das National Bureau aof Economic

Research in Cambridge/Massachusetts), die nachweisen, dass Selbstmordattentäter "keineswegs immer arm und ungebildet" sind. Heinrich Wefing wirft einen Blick auf die amerikanische Rechtspraxis - der Supreme Court hat eine Klage zweier Männer abgelehnt, die ihre Strafen von 25 beziehungsweise 50 Jahren für wiederholten Ladendiebstahl als unangemessen empfanden.

(http://www.perlentaucher.de/feuilletons/2 003-03-07.html - Anexado em 03/06/2007)
Cb26. Grit Breuer (Magdeburgo) esteve presente como única velocista de 400 metros. No entanto, não havia nenhum corredor no time da DLV [Federação Alemã de Atletismo]. Vários atletas desistiram de antemão da disputa pelo título Hallen, $\underline{\mathbf{e}}$ até mesmo da temporada completa, para poderem se preparar mais longamente para o campeonato mundial de Paris, em agosto.
Cb28. Laut dem Memorandum soll die Abhöraktion nicht nur Erkenntnisse über das mögliche Abstimmungsverhalten im Falle einer zweiten Uno-Resolution
Cb27. Reinhard Wandtner cita dois estudos (de Scott Atran em Science e de Alan

Krueger e Jitka Maleckowa para o National Bureau of Economic Research em

Cambridge/Massachusetts), que comprovam que os autores de um atentado suicida não são "de forma alguma sempre pobres e incultos". Heinrich Wefing lança um olhar sobre a prática legal americana a Suprema Corte rejeitou a ação judicial de dois homens que consideravam inadequadas suas penas de $25 \underline{\mathbf{e}} 50$ anos por repetidos furtos a lojas.
Cb28. Conforme o memorando, a escuta telefônica deve conter não apenas informação sobre o possível resultado da votação no caso de uma segunda resolução 


\begin{tabular}{|c|c|}
\hline $\begin{array}{l}\text { bringen, sondern auch generell } \\
\text { Informationen über } \\
\text { "Verhandlungspositionen", "Politik", } \\
\text { "Allianzen" und "Abhängigkeiten". Ziel sei } \\
\text { es, dass US-Vertreter vor Überraschungen } \\
\text { gefeit seien beziehungsweise einen Vorteil } \\
\text { für die von den USA angestrebten Ziele im } \\
\text { Uno-Sicherheitsrat erhielten, zitiert das } \\
\text { Blatt weiter aus dem Memorandum. } \\
\text { (http://www.politikforum.de/forum/archive } \\
\text { /index.php/t-27049.html - Anexado em } \\
\text { 05/05/2007) }\end{array}$ & $\begin{array}{l}\text { da ONU, mas também informações gerais } \\
\text { sobre "posições de negociação", "política", } \\
\text { "alianças" e "dependências". O } \\
\text { memorando menciona também que o } \\
\text { objetivo seria tornar os representantes dos } \\
\text { Estados Unidos imunes a surpresas e obter } \\
\text { vantagem para os objetivos almejados } \\
\text { pelos Estados Unidos no Conselho de } \\
\text { Segurança da ONU. }\end{array}$ \\
\hline
\end{tabular}

Cb29. Dieser Zustand könnte jedoch früher enden als dem Handel lieb ist: „Wenn wir sehen, dass der Handel auf Zeit spielt, werden wir uns dafür einsetzen, dass die Übergangsregelung schon vor dem 1 . Oktober außer Kraft gesetzt wird", droht Resch. Konsequenz: Entweder nimmt der Händler Einwegverpackungen ganz aus seinem Sortiment oder er muss jede Dose annehmen und auf eigene Faust versuchen, von der Konkurrenz beziehungsweise der Getränkeindustrie die entsprechenden Pfandgelder einzutreiben. Bei Verstößen drohen pro Einzelfall 250000 Euro Ordnungsgeld. (http://www.tagesspiegel.de/wirtschaft/arch iv/22.02.2003/450048.asp - Anexado em 05/06/2007)

Cb30. Es muss sich lediglich um die gleiche Reifenbauart handeln, so die Straßenverkehrzulassungsordnung (StVZO, Paragraf 36, Absatz 2a) vor. Gemeint ist damit der so genannte Radialreifen beziehungsweise der Diagonalreifen. Diese sind häufig aber nicht mehr in der Profilausführung der übrigen Pneus verfügbar.

(http://www.spiegel.de/auto/werkstatt/0,15 18,234619,00.html - Anexado em 05/06/2007)
Cb29. Essa situação, porém, poderia terminar mais cedo do que o comércio gostaria: "Se notarmos que o comércio está tentando ganhar tempo, vamos defender que a regulamentação transitória seja revogada já antes de $1^{\circ}$. de outubro", ameaça Resch.

Consequiência: ou o comerciante retira totalmente do seu estoque as embalagens descartáveis ou aceita qualquer recipiente e tenta cobrar por conta própria, da concorrência e da indústria de bebidas, o valor correspondente ao depósito. Em caso de infração, a penalidade para cada caso isolado ameaça ser de 250.000 euros.
Cb31. Auch bei Einkäufen in Thailand und Australien haben Touristen nach Angaben der jeweiligen Fremdenverkehrsämter das
Cb30. Deve-se tratar exclusivamente do mesmo tipo de pneu, segundo o código de trânsito (parágrafo 36, alínea 2a.). A menção é feita devido aos chamados pneu radial e pneu diagonal. Estes são encontrados com freqüência, mas não no padrão de banda de rodagem dos demais pneus.
Cb31. Também em compras na Tailândia e na Austrália, segundo informações das respectivas secretarias de turismo, os 


\begin{tabular}{|c|c|}
\hline $\begin{array}{l}\text { Recht auf Erstattung der Mehrwertsteuer. } \\
\text { Das Prozedere ähnelt dem in Norwegen } \\
\text { und Kanada: Die Waren müssen insgesamt } \\
\text { einen Mindestwert von umgerechnet rund } \\
\text { 120, } 165 \text { beziehungsweise } 205 \text { Euro } \\
\text { haben. Die zuständigen Stellen an } \\
\text { Flughäfen oder Grenzübergängen } \\
\text { verlangen Pass, Bordkarte oder einen } \\
\text { anderen Beleg für die Ausreise. } \\
\text { (http://www.stern.de/wirtschaft/geld/26152 } \\
\text { 5.html?eid=501470 - Anexado em } \\
\text { 05/06/2007) }\end{array}$ & $\begin{array}{l}\text { turistas têm direito ao reembolso do } \\
\text { imposto sobre o valor agregado. O } \\
\text { procedimento se assemelha ao da Noruega } \\
\text { e do Canadá: as mercadorias devem ter no } \\
\text { total um valor mínimo que, convertido, seja } \\
\text { equivalente a cerca de } 120,165 \text { e } 205 \\
\text { euros. Os locais competentes em aeroportos } \\
\text { ou postos da fronteira exigem passaporte, } \\
\text { cartão de embarque ou outro comprovante } \\
\text { de viagem. }\end{array}$ \\
\hline
\end{tabular}

Cb32. Strieder wurde im Hauptausschuss aufgefordert, in allen 141 Einzelfällen zu begründen, warum er 2003 mehr ausgeben bzw. weniger einnehmen will als im Vorjahr. „Das ist überhaupt nicht einsehbar, in anderen Ressorts wird erbittert um 50000 Euro gefeilscht", kritisierte der Grünen-Haushälter Oliver Schruoffeneger. Auch der Senat hat inzwischen gemerkt, dass im Stadtentwicklungsressort Geld zu holen ist. (http://www.tagesspiegel.de/berlin/;art270, 2138953 - Anexado em 06/06/2007)
Cb32.Na comissão principal, solicitou-se a Strieder para justificar, em todos os 141 casos isolados, por que em 2003 ele disse que gastou mais e/ou, recebeu menos do que no ano anterior. "Isso não é nada compreensível; em outros departamentos barganha-se com fúria por 50.000 euros", criticou Oliver Schruoffeneger, especialista financeiro do Partido Verde. Também o Senado percebeu, nesse ínterim, que o Departamento de Desenvolvimento das Cidades deve economizar.
Cb33. Die Werke gleich vier bekannter Künstler zeigt die Gemeinschaftsausstellung „Kunst und Natur" im Kurhaus Meran, die am 26. April um 18.30 Uhr eröffnet wird. Franz Lenhart, Ivo Mahlknecht, Gigi Picelli und Mario Trippa heißen die Maler, die alle im Raum Meran tätig sind bzw. waren. (http://www.sunshine.it/index.php?option= com_content\&task=view \&id=5068\&Itemi $\mathrm{d}=39$ - Anexado em 12/06/2007)
Cb33. As obras de quatro artistas igualmente conhecidos serão exibidas na exposição "Arte e Natureza" do Spa Meran que será inaugurada no dia 26 de abril, às 18h30. Franz Lenhart, Ivo Mahlknecht, Gigi Picelli e Mario Trippa são os pintores que atuam e/ou atuaram no espaço Meran.
Cb34. Stille Nacht. "Eine angstvolle, kopflose Erregung, die bei plötzlich und unerwartet hereinbrechender Gefahr (sei sie nun tatsächlich oder nur vermeintlich vorhanden) bei einzelnen oder einer Gruppe auftritt und einen

,Bewegungssturm' auslöst, eine chaotische und sinnlose Überproduktion von Bewegungen und Fluchtreaktionen bei
Cb34. Noite Feliz. "Uma agitação angustiada, desnorteada que, diante do perigo repentino e inesperado que se aproxima (seja ele real ou então apenas hipotético), se apresenta para uma pessoa ou um grupo e desencadeia uma 'tempestade de movimentos', uma produção excessiva, caótica e sem nexo de movimentos e reações de fuga diante do 


\begin{tabular}{|l|l|}
\hline $\begin{array}{l}\text { lahmgelegter rationaler Kontrolle." So der } \\
\text { Brockhaus ("Wissen ist Macht") über Panik }\end{array}$ & $\begin{array}{l}\text { controle racional paralisado.” Segundo a } \\
\text { enciclopédia Brockhaus ("Saber é poder"), } \\
\text { bzw. Weihnachten. }\end{array}$ \\
$\begin{array}{l}\text { (http://www.zeit.de/1997/01/finis01.txt.199 seus verbetes sobre pânico e/ou Natal. } \\
\text { 71226.xml - Anexado em 012/06/2007) }\end{array}$ & \\
\hline
\end{tabular}

Cb35. Staatsrechtliche Beschwerde gegen den Entscheid der Justiz-, Gemeinde- und Kirchendirektion des Kantons Bern, vom 6. Januar 2006.

Sachverhalt:

A.

Am 16. Mai 2004 nahmen die

Stimmberechtigten der Stadt Bern das

Reglement

über die Reklame in der Stadt Bern

(Reklamereglement, RR) an. Die neuen

Reklamevorschriften ergänzen bzw. ändern

die bestehende, baurechtliche

Grundordnung der Stadt Bern; sie gelten

für Reklamen auf öffentlichem und

privatem Grund.

(http://jumpcgi.bger.ch/cgi-

bin/JumpCGI?id=05.07.2006_1P.84/2006 -

Anexado em 12/06/2007)
Cb35. Recursos constitucionais contra a decisão da justiça, da comunidade e da

. direção da Igreja do Cantão de Berna em 6 de janeiro de 2006. Fatos:

A.

Em 16 de maio de 2004, os eleitores da cidade de Berna aprovaram o regulamento sobre publicidade na cidade de Berna (Regulamento sobre Publicidade, RP). Os novos preceitos sobre publicidade complementam e/ou alteram a atual ordem básica relativa às leis de planejamento na cidade de Berna; são válidas para publicidade pública e privada.
Cb36. HANS GÜNTHER BASTIAN:

Sicher nicht im Sinne eines Kochrezeptes: "Man nehme Musik ..." Es gibt nicht die Wirkung der Musik auf den Menschen. Aber wir haben festgestellt, dass bei den Kindern mit musikbetontem Unterricht die soziale Kompetenz viel ausgeprägter ist. Es gibt in den Klassen weniger ausgegrenzte Schüler, so die eindeutigen Befunde unserer Soziogramme, denen die Frage zugrunde lag: Welchen Schüler in deiner Klasse magst bzw. magst du nicht so gerne? In diesem sozialen Bereich sind die Ergebnisse für mich zum Teil sensationell. (http://www.gagschule.kwe.de/fach/musik/bastian.htm Anexado em 12/06/2007)
Cb36. HANS GÜNTHER BASTIAN:

Certamente não lembra uma receita culinária: "Pega-se música..." Não há o efeito da música sobre o homem. Mas verificamos que, em crianças cuja educação salienta a música, a competência social é muito mais pronunciada. Nas salas de aula existem menos alunos segregados, segundo os resultados inequívocos do nosso sociograma, os quais foram submetidos à pergunta: De que aluno da classe você gosta e/ou não gosta tanto? Para mim, nesse âmbito social os resultados são em parte sensacionais. 
Cb37. Erst einmal teilt sie die Summe zwischen Hochschulen und außeruniversitären Forschungseinrichtungen: 150 Millionen Euro gehen in letztere, 1,2 Milliarden in die Hochschulen. Soweit die Ausgaben. Gibt es auch Einnahmen dadurch? Einige schon, stellt sich heraus. Die 150 Millionen für die außeruniversitäre Forschung sind gut angelegt. Denn sie wandern in sogenannte mischfinanzierte Institute. Bei diesen tragen der Bund bzw. die Ländergemeinschaft zwischen 50 und 90 Prozent der Kosten. Der Berliner Einsatz von 150 Millionen spült dadurch unmittelbar 409 Millionen Euro aus nichtberliner Kassen in die Stadt. (http://www.berlinews.de/archiv2003/1317.shtml - Anexado em 06/06/2007)
Cb37. Apenas uma vez divide-se a soma entre escolas de nível superior e instituições de pesquisa não-universitárias: 150 milhões de euros vão para as últimas, 1,2 bilhão para as escolas de nível superior. Até aqui despesas. Daí provêm também receitas? Algumas, conforme divulgado. Os 150 milhões para a pesquisa nãouniversitária são bem investidos. Pois rumam para os chamados institutos de financiamento misto.

Nesses institutos, o governo federal e/ou a comunidade formada pelos estados arcam com 50 a 90 por cento dos custos. Assim, o aporte berlinense de 150 milhões atrai de forma direta para a cidade 409 milhões de euros provenientes de fora.
Cb38. Leichter Anstieg: 346 verbürgte

Kredite und Beteiligungen

Mit 346 verbürgten Krediten und Beteiligungen über ca. 83 Mio. Euro (Vorjahr: 363 / 81 Mio.) verzeichnet die Bürgschaftsbank Brandenburg einen leichten Anstieg von drei Prozent bei der bewilligten Bürgschaftssumme.

Brandenburg liegt damit leicht über dem Bundesdurchschnitt. Das Neugeschäft bewirkte Investitionen in Höhe von 162 Mio. Euro (+ 13 Prozent), womit fast 5100 Arbeitsplätze (+ 32 Prozent) geschaffen bzw. gefestigt wurden. (http://www.prcenter.de/70-000Arbeitsplaetze-2-4-Milliarden-EuroInvestitionen-in-15-Jahren.257.html) Anexado em 12/06/2007
Cb38. Leve aumento: 346 créditos e participações garantidas

Com 346 créditos e participações garantidas equivalentes a cerca de 83 milhões de euros (ano anterior: 363 / 81 milhões), o banco de garantias de Brandenburgo registra um leve aumento de três por cento no total de garantias concedidas. Assim, Brandenburgo fica um pouco acima da média do país. A nova operação implicou em investimentos no valor de 162 milhões de euros $(+13$ por cento), com isso quase 5100 empregos $(+$ 32 por cento) foram gerados $\underline{\mathbf{e} / \mathbf{o u}}$ consolidados.

Cb39. Eine Aktiengesellschaft kann ihr Cb39. Uma sociedade anônima pode Kapital entweder aus Eigenmittel oder levantar capital por meio de recursos durch die Zusammenlegung próprios, fusão, ou ainda, emissão de beziehungsweise die Ausgabe von neuen novas ações. Em 2001, a corporação Aktien durchführen. Bei der bancária Berlin teve de elevar seu capital Bankgesellschaft Berlin musste das Kapital em 1,75 bilhão de euros. 
im Jahr 2001 um 1,75 Milliarden Euro

erhöht

werden.

(http://www.tagesspiegel.de/wirtschaft/arch

iv/25.03.2003/494938.asp - Anexado em

03/06/2007) 


\section{Discussão dos resultados}

Os resultados obtidos a partir das análise dos dados do corpus mostraram que, em português, as traduções mais apropriadas para beziehungsweise, de acordo com sua freqüência de uso, são as conjunções "e", "ou" e o advérbio "respectivamente".

No entanto, ao consultar a palavra beziehungsweise nos dicionários bilíngües, o consulente encontrará como definição principal as palavras "respectivamente; ou seja" (cf. LANGENSCHEIDT 2001:719 e outros); de modo que essa ordem de critério de escolha na tradução para o português não corresponde ao seu uso mais freqüente em língua alemã, conforme mostram os dados da pesquisa. As possibilidades de correspondência com "e" e "ou" não são sequer mencionadas nos dicionários bilíngües, apesar de serem as correspondências mais freqüentes no corpus.

Em conseqüência disso, há uma grande possibilidade de uma defasagem na busca de um correspondente em português para beziehungsweise, que levaria o consulente a uma opção de tradução equivocada ou insatisfatória em sua busca por um correlato para a palavra.

Por outro lado, um brasileiro que quisesse utilizar beziehungsweise em textos escritos na língua-alvo a partir dos dados oferecidos pelos dicionários português-alemão se restringiria aos usos que aparecem com freqüência nos dicionários bilíngües, de modo que não abarcaria todos os possíveis usos reais da palavra em alemão.

Todos os três tipos de uso indicados no LANGENSCHEIDT (2003:172) estão representados no corpus, e sua investigação mostrou-se frutífera para auxiliar no esclarecimento das possibilidades de uso de bzw. na íngua alemã e de sua tradução para o português.

O tipo de uso que expressa uma relação biunívoca, apesar de ser o tipo com menor freqüência de uso no corpus, é o grupo mais homogêneo em termos de tradução, sendo que apenas uma ocorrência do corpus não foi traduzida para o português como "respectivamente". Este tipo de uso parece não trazer problemas para os tradutores brasileiros e provavelmente poderá ser produzida por aprendizes brasileiros de alemão que tenham sido sensibilizados 
para a identificação dessa relação biunívoca.

O tipo com segunda maior freqüência de uso é o de precisão da informação, o que mostra que bzw. é, no alemão contemporâneo, usado com muita freqüência com um caráter explicativo. Apesar de Engel (cf. 1988:741) em sua gramática considerar este uso como "incorreto", aconselhando o uso de nämlich, podemos levantar a hipótese de que o uso de bzw. neste contexto já passou a ser aceito como normal, já que a maioria das ocorrências provêm da revista Der Spiegel, que apresenta uma linguagem de nível culto.

Nas ocorrências analisadas, observa-se um jogo entre domínios maiores e menores, aos quais os elementos estão subordinados, sendo que bzw. assume o papel de um focalizador, seja expandindo ou restringindo o foco da informação. Neste tipo, "ou melhor" se apresenta como a forma prototípica de tradução para o português e também não deve apresentar problemas para o aprendiz ou para o tradutor.

O tipo de maior ocorrência é o que expressa exatamente a alternatividade nas relações estabelecidas entre os elementos unidos por bzw. A análise das ocorrências do corpus levou à constatação de que este tipo de uso na realidade engloba dois grandes subtipos, sendo que bzw. pode ser usado para relacionar alternativas excludentes ou não excludentes. As alternativas não-excludentes foram mais freqüentes no corpus, embora isso possa se dar pelo fato de que este subtipo engloba várias possibilidades de combinações de elementos, enquanto as alternativas excludentes se reduzem a duas.

Em português, a relação de alternatividade excludente foi expressa unicamente através da conjunção "ou", enquanto a alternatividade nãoexcludente tem a conjunção "e" como tradução prototípica.

$\mathrm{Na}$ alternatividade não-excludente, $\mathrm{O}$ apagamento da atribuição e especificação de relações permite que, em português, $b z w$. seja traduzido com maior freqüência por "e", marcando apenas a formação de um conjunto composto por várias opções. No entanto, o uso de bzw. em alemão continua apontando que as ações acontecem de modo alternado, quando originadas do mesmo elemento, ou que se originam de elementos diferentes que as realizam separadamente, mesmo que a relação não seja especificada completamente. 
Esse traço se perde na tradução em português, ficando totalmente dependente do contexto.

Há ainda a possibilidade de utilizar a expressão "e/ou" para traduzir bzw. nestes contextos específicos. A expressão "e/ou" deixa em aberto se o conteúdo dos elementos conectados deve ser considerado como alternativo ou comum. Desse modo, mantém-se a alternatividade expressa por "ou", mas eliminando o seu efeito de exclusão (cf. PASCH 2003: 455s), ao mesmo tempo que se minimiza o efeito de conjunto homogêneo criado por "e".

A conjunção coordenativa "e" em português pode causar ambigüidade em sua interpretação porque, segundo Neves (cf. 1999:358), "a coordenação permite tanto a interpretação coletiva como distributiva dos elementos envolvidos."

Assim em "João e Maria viram um fantasma" (NEVES 1999:358) existe a possibilidade de a frase ser interpretada das seguintes formas: a) os dois viram um fantasma e b) cada um viu um fantasma, de modo que a) é uma interpretação coletiva e b) uma interpretação distributiva.

Em alemão um dos usos da conjunção und ("e" em português), segundo Engel (1988:746) "sinaliza uma validade coletiva de dois elementos mais freqüentes". ${ }^{20}$

Desse modo em Er verlor Geld und Vertrauen (Ele perdeu o dinheiro e a confiança), podemos entender que a) perdeu a confiança em conseqüência da perda de dinheiro ou b) perdeu ambos de maneira adicional, ou seja, poderia ter perdido outras coisas a serem elencadas em listas de perdas.

Se "confiança" e "dinheiro" estivessem ligados entre si pela conjunção beziehungsweise não haveria margem pra se duvidar de que a perda de confiança está intimamente ligada à perda do dinheiro, já quem neste contexto "confiança" e "dinheiro" estariam dentro de um mesmo campo de relações.

Em português, para expressarmos essa idéia de que a perda da confiança resultou da perda de dinheiro utilizaríamos uma conjunção consecutiva "e" ou "logo". A relação expressa pela conjunção "e" neste caso é, segundo MATEUS (cf. 1983:396), de condição-conseqüência, em que "os elementos coordenados podem assumir uma causalidade."

20 Der Konjunktor und signalisiert gemeinsame Geltung zweier häufter Elemente. (ENGEL 1988:746) 
O uso da conjunção "e" numa situação dessas em português apenas teria um valor aditivo e o mesmo se daria com o uso de und em alemão. Beziehungsweise nestes casos expressa uma idéia de destaque. Em português, o mesmo não ocorre com o uso de "e", de modo que é imprescindível utilizar o contexto para expressarmos a mesma idéia.

Em alemão, segundo a Duden Grammatik (2005: 628), "pela enumeração de mais que duas partes em uma série de palavras, und posiciona-se antes do último elemento. Para maior destaque, und pode ser posicionado-se antes de cada elemento"21. Dessa forma, und apenas enumera itens que podem ter um aspecto de neutralidade, não interferindo nas relações entre os elementos ligados por ele.

A conjunção und pode também enumerar seqüências de fatos, como mostra o exemplo Sie kam, sah und siegte. (idem) ("ele veio, viu e venceu"). Já beziehungsweise, segundo Engels, necessariamente apresenta uma "validade alternativa" (alternative Geltung) (ENGEL 1988:741) para \#os elementos que une. Assim, em Sie pflanzten Birken bzw. Pappeln längs der straße an (ENGEL, 1988:741) ("Eles plantavam bétulas e choupos nas ruas"), trata-se de diferentes ruas nas quais são plantados diferentes tipos de plantas. O uso de und simplesmente daria margem às interpretações de que ambas são plantadas em quaisquer ruas em questão ou que ambas são plantadas sem dar o destaque exato de que ruas são plantadas cada qual.

A maior dificuldade de se usar o beziehungsweise neste sentido encontra-se no fato de que em português a conjunção "e" não expressa 0 sentido restrito que beziehungsweise expressa em suas relações.

A conjunção "ou" em português expressa necessariamente alternatividade. Ela apresenta opções de escolha ou de possibilidades de ocorrência de um dos eventos mencionados, de modo que pode ocorrer uma inclusão ou exclusão. Por exemplo, em "Eu quero comer sorvete ou torta de morango" ocorre inclusão, pois quero qualquer um dos dois. Por outro lado, em "Eu quero comer sorvete ou torta de morango, já que estou de regime", há a exclusão que é determinada pelo contexto. No caso de "Eu quero comer ou

21 Bei der Aufzählung mit mehr als zwei Teilen einer Wortreihe steht und vor dem letzten Element. Zur besonderen Hervorhebungen kann und vor jedem Element stehen. (DUDEN GRAMMATIK 2005:628) 
sorvete ou torta de morango", ocorre a exclusão pela repetição da conjunção "ou".

Em alemão, essa exclusão pela dupla conjunção pode ser expressa por entweder... oder, como no exemplo, Entweder ist er schwer krank oder er simuliert meisterhaft (ENGEL 1988:744) ("Ou ele está gravemente doente, ou ele simula magistralmente").

No entanto, o uso de beziehungsweise implica necessariamente uma relação com os elementos envolvidos de modo que estão (ou não) contidas dentro de um micro/macrocosmo. Assim, no exemplo Ca.8 retirado do corpus: Ansonsten besorgen Sie sich aus dem Sekretariat des Praktikumbüros oder auf der Web-Seite des Praktikumsbüros das Formblatt „Praktikumsbescheinigung“ für das Grundstudium bzw. für Hauptstudium. (Caso contrário, obtenha junto à secretaria da Central de Estágios ou no website da Central o formulário "certificado de estágio" para o nível básico ou avançado. ), "básico/avançado" possuem uma relação específica com "certificado", estão contidos na entidade "certificado". 


\section{Considerações finais}

A conjunção beziehungsweise é muito pouco estudada ou mesmo mencionada pelas gramáticas e dicionários do alemão e do português. Esta pesquisa busca salientar a importância de se estudar com maior profundidade o uso desta conjunção, já que ela apresenta uma riqueza de uso maior do que se imagina. Assim, também apresenta maiores dificuldades de usos, pois, a linha tênue que a separa do uso de outras conjunções como und e oder, e locuções adverbiais como dass heißt e besser gesagt é muitas vezes ignorada ou despercebida.

O tratamento parcial dado pelas gramáticas a respeito de beziehungsweise se limita a dizer que se trata de uma conjunção que expressa alternatividade e especificação de algo já mencionado. Os dicionários alemãoportuguês se restringem a traduzir a conjunção como "respectivamente" e "ou seja", mostrando o aspecto explicativo sem apresentar o aspecto alternativo que a conjunção também pode expressar.

O principal traço da conjunção beziehungsweise, pelo que se pode verificar no corpus, é a alternatividade. Essa alternatividade se sobrepõe em relação aos casos em que beziehungsweise expressa especificação da informação.

No entanto essa alternatividade não se resume a "uma coisa ou outra". Ela focaliza diferentes relações de forma independente, mesmo que apareçam como um conjunto. Isso pôde ser verificado através dos exemplos do corpus, os quais levaram à seguinte divisão de beziehungsweise quanto ao uso:

- relação biunívoca: em que duas informações correspondem biunivocamente a duas outras;

- precisão da informação: em que há um detalhamento do que já foi mencionado;

- alternatividade: que pode ser excludente ou sem exclusão.

A partir das amostras analisadas nesta pesquisa, demonstrei empiricamente que o uso mais recorrente na língua alemã atual é o de beziehungsweise expressando a alternatividade. Sendo assim, a indicação 
prototípica de beziehungsweise em dicionários bilíngues alemão-português expressando a idéia de "respectivamente" (ou seja, duas informações correspondendo biunivocamente a duas outras), não corresponde ao que ocorre na língua atualmente, de modo que é necessário que sejam feitas reformas na maneira como é apresentado este conector pelos dicionários bilíngües alemão-português.

Além disso, faz-se necessário salientar que em português "respectivamente' não marca as outras relações indicadas com o uso de beziehungsweise, que em português correspondem a "e" e " ou", já que podem ser aplicados a várias situações. Além disso, em português, no caso de sentenças unidas por "ou" ou por "e", se não houver um contexto mais abrangente explícito, podemos interpretar tanto que a mesma ação será aplicada a ambos os elementos do conjunto como que cada ação será executada independentemente.

A investigação empírica realizada nesta pesquisa, mesmo com uma representatividade restrita devido à pequena abrangência da amostra, demonstra claramente a importância de tais estudos para a descrição de como fenômenos lingüísticos realmente se apresentam na comunicação, o que deve servir de base para ações lexicográficas e conseqüentes repercussões nos campos da tradução e do ensino/aprendizagem de línguas estrangeiras.

Partindo-se do pressuposto de que uma língua está em transformação constante e que há mudanças quanto ao uso de expressões, vocábulos e mesmo conectores, a realização de pesquisas minuciosas de determinados aspectos da língua (no caso desta pesquisa, o uso do conector beziehungsweise) vem a enriquecer e contribuir para uma melhor compreensão e usufruto da língua alemã como língua estrangeira. 


\section{Referências Bibliográficas:}

AGRICOLA, Erhard. Wörter und Wendungen - Wörterbuch zum deutschen Sprachgebrauch. Mannheim/Leipzig/Wien/Zürich: Duden Verlag, 1992.

Althaus, Hans Peter. et. alli. Lexikon der Germanistischen Linguistik. Tübingen: Max Niemeyer Verlag, 1980.

BARRos, Enéas Martins de. Nova Gramática da língua Portuguesa. São Paulo: Editora Cultrix, 1985.

Bechara, Evanildo. Moderna Gramática Portuguesa. Rio de Janeiro: Lucerna, 2000.

BuschA, Joachim. Lexikon deutscher Konjunktionen. Leipzig: Verlag Enzyklopädie, 1989.

CAMACHO, Roberto Gomes. Estruturas Coordenadas Aditivas. In: Gramática do Português Falado, Maria Helena de Moura Neves (org). Campinas: Editora da Unicamp, 1999.

CunHA, C. F. Gramática da Língua Portuguesa. Rio de Janeiro, FENAME, 1972.

Cunha, Celso \& Cintra, Lindley. Nova Gramática do Português Contemporânea. Rio de Janeiro: Nova Fronteira, 1985.

DUDEN - Deutsches Universalwörterbuch. Mannheim / Leipzig / Wien / Zürich: Dudenverlag, 2007.

DUDEN - Die Grammatik (Duden Band 4). Mannheim / Leipzig / Wien / Zürich: Dudenverlag, 2005.

DUDEN - Grammatik der deutschen Gegenwartssprache (DUDEN BAND 4). Mannheim / Leipzig / Wien / Zürich: Dudenverlag, 1995.

EICHLER, Wolfgang. Deutsche Grammatik: Form, Leistung u. Gebrauch $d$. Gegenwartigssprache. Karl-Dieter-Büntig - 3 Auflage - Könistein/ts., 1986.

Eisenberg, Peter. Grundriss der deutschen Grammatik, Band 2: Der Satz. Stuttgart: J.B.Metzler, 2006.

EnGEL, Ulrich. Deutsche Grammatik. Heidelberg: Julius Groos, 1988.

Faraco, Carlos Emílio \& Moura, Francisco Marto de. Língua e Literatura. São Paulo: Editora Ática, 1993. 
GARCIA, Othon M. Comunicação em Prosa Moderna: aprenda a escrever, aprenda a pensar. Rio de Janeiro: Editora da Fundação Getúlio Vargas, 1982.

GöTZE, LUTZ. Grammatik der deutschen Sprache. München: Knaurs, 1992.

GROSSWÖRTERBUCH Deutsch als Fremdsprache. Berlin und München: Langenscheidt, 2003.

Hentschel, Elke \& Weydt, Harald. Handbuch der deutschen Grammatik. Berlin: Walter de Gruyter, 1994.

HentSchel, Elke. \& WeYdT, Harald. Handbuch der deutschen Grammatik. Berlin: Walter de Gruyter, 1994.

HERINGER, Hans Jürgen. Lesen lehren lernen: eine rezeptive Grammatik des Deutschen. Tübingen: Max Niemeyer Verlag, 1989.

JUNG, Walter. Deutsche Grammatik - Grammatik der Deutschen Sprache. Leipzig: Bibliographisches Institut, 1990.

KEMPCKE, Günter. Wörterbuch Deutsch als Fremdsprache. Berlin, New York: Walter de Gruyter, 2000.

KoCH, I. \& VILELA, M. Gramática da Língua Portuguesa. Coimbra: Almedina, 2001.

LANGENSCHEIDT. Grosswörterbuch Deutsch als Fremdsprache. Berlin, München, Wien, Zürich, New York: Langenscheidt, 2003.

LANGensCheidT. Taschenwörterbuch Portugiesisch. Berlin, München, Wien, Zürich, New York: Langenscheidt, 2001.

LINKE, Angelika. Sudienbuch Linguistik. Tübingen: Niemeyer, 1994.

MaIA, J. D. Português. São Paulo: Ed. Ática, 2003.

Mateus, Maria Helena Mira. Gramática da Língua Portuguesa. Coimbra: Livraria Almedina, 1983.

Neves, Maria Helena de Moura. Gramática do Português Falado. Campinas: Editora da Unicamp, 1999. Coleção Novos Estudos, vol. 07.

$\mathrm{PASCH}$, Renate. et. al. Handbuch der deutschen Konnektoren. Berlim, New York: Walter de Gruyter, 2003.

PASCHOALIN, Maria Aparecida. Gramática - teoria e exercícios, São Paulo: FTD, 1996. 
PeZATTI, Erotilde Goreti. Estruturas Coordenadas Alternativas. In: Gramática do português Falado. Vol. 7. Novos Estudos, Campinas: Editora da Unicamp, 1999.

PORTO. Dicionário alemão/português. Coimbra: Porto Editora, 1986.

PORTO. Dicionário alemão/português. Coimbra: Porto Editora, 1987.

ReIMANN, Monika. Grundstufen-Grammatik. München: Max Hueber Verlag, 2001.

SARDINHA, Tony Berber. Lingüística de Corpus. Barueri: Manole, 2004.

Schulz, Dora \& GriesbaCH, Heinz. Grammatik der deutschen Sprache. München: Hueber, 1960.

SOMMERFELD, Karl-Ernst et alli. Grammatisch-semantische Felder. Berlin: Langenscheidt Verlag Ensyklopädie, 1991.

SOMmeRFELD, Karl-Ernst. Et alli. Grammatisch-semantische Felder. Berlin: Langenscheidt Verlag Ensyklopädie, 1991.

Tochtrop, Leonardo. Dicionário Alemão-Português. Porto Alegre: Editora GLOBO, 1968.

WAHRIG Deutsches Wörterbuch. Gütersloh:Verlangsgruppe Bertelsmann, 1968.

WELKER, Herbert Andreas. Gramática Alemã. Brasília: Universidade de Brasília, 2003.

www.worstschatz.uni-leipzig.de - exemplos do corpus selecionados em março de 2007.

ZIFOnUn, Gisela et alli. Grammatik der Deutschen Sprache. Band 3. Walter de Gruyter: Berlin/New York, 1997. 